INSTITUTO DE PESQUISAS ENERGÉTICAS E NUCLEARES

Autarquia associada à Universidade de São Paulo

\title{
COMPARAÇÃO DE DOIS MÉTODOS DE OBTENÇÃO CELULAR PARA CULTURA PRIMÁRIA DE QUERATINÓCITOS BUCAIS HUMANOS
}

MARIA FÁTIMA GUARIZO KLINGBEIL

Dissertação apresentada como parte dos requisitos para obtenção do Grau de Mestre em Ciências na área de Tecnologia Nuclear- Aplicações

Orientadora:

Dra. Monica Beatriz Mathor

São Paulo

2006 
Ao Ulrich agradeço por toda ajuda, pela compreensão, pela paciência e principalmente pela tolerância durante toda minha longa ausência.

À Désirée e Natascha agradeço pela compreensão pela minha falta de atenção, distância e afastamento. 


\section{Agradecimentos}

À Dra. Monica Beatriz Mathor, pelo trabalho e exemplo, pela incansável orientação, dedicação, paciência, amizade, principalmente pela confiança e pelo fato de ter se permitido fazer parte do currículo da minha vida.

Ao IPEN, pela oportunidade do desenvolvimento deste trabalho.

Ao CTR, pelo acolhimento.

Ao CBM, pelo acolhimento e por permitir a utilização das instalações e propiciar condições para o desenvolvimento do trabalho.

À Divisão de Ensino, especialmente à Ilze Puglia e ao Fernando Moreira, pelo apoio e atenção.

À FMUSP, pelo acolhimento e por permitir a utilização do laboratório para a continuidade do trabalho.

À FOUSP, pelo acolhimento e por permitir a utilização dos laboratórios.

À Dra. Marisa Roma Herson, pelo exemplo, pela grande ajuda, atenção, carinho e amizade.

Ao Prof. Dr. Décio dos Santos Pinto Junior, pela co-orientação, pelo exemplo, pela ajuda, atenção, apoio e amizade.

À Dani e ao Tiago, pela grande ajuda, colaboração e amizade.

À Andrea C. D. Rodas por todos os ensinamentos, pela ajuda, colaboração e amizade.

À Bete, ao Carlos, Hélio e Samir, pela colaboração e ajuda, carinho e amizade.

Aos colegas de equipe: Selma, Patrícia, Mirna, Cynara, Cesar, Tatu, Júnior e Gislaine, pela camaradagem e amizade.

Ao Helder pela grande ajuda prestada.

À Silvana pela ajuda e amizade.

À todos os professores do CBM, especialmente à Dra.Olga Zazuco Higa, Dra. Lígia Ely Morganti. Ferreira Dias, Dr. Patrick Jack Spencer e Dra. Cibele Nunes Peroni.

À todos os colegas do CBM, especialmente à Rosa e à Claudinha.

Aos queridos pacientes voluntários, pois sem essa preciosa colaboração não teria sido possível a realização deste trabalho. 
A todos os colegas e amigos que contribuíram e colaboraram para a realização deste trabalho: Dra. Maristher Fabretti dos Santos Pinto, Dr. Ivan Squiozer, Dr. Clóvis Bandeira, Dr. Hamilton e Dr. Sandro Bellini, Dr. João Carlos C. Paixão, Dr. Gustavo Abissamra Issas, Dr. Marcos de Cacerda, Dra. Lúcia Coutinho Porto, Dra. Kátia Mayne Moyla, Dra. Ana Paula Moraes Shuter, Dra. Lícia e Dr. Marcos Pizzocolo, Dr. Márcio Kimura, Dr. Luis Eduardo de Abreu, Dr. Reginaldo e Dra. M. Imaculada de Moraes, especialmente ao Dr. Luis Carlos Trefílio e ao Dr. Pérsio Bianchini Mariani.

Às meninas, pela ajuda e paciência: Cassiana, Joelma, Mari, Joelma e Erika.

Aos secretários, pela ajuda: Rute, Cláudia e Marcos.

À equipe da biblioteca do IPEN.

Ao Toninho e Juliana, pela colaboração.

Ao Omar e Johny pela grande ajuda.

Ao Wilson pela colaboração e ajuda.

À Rute e Celme pela ajuda e colaboração.

Aos tantos socorros prestados: Dra. Wânia, Kelly, Dra Valéria e Dr. Kim.

À Elizabeth, tia Ada e Cida, pela força e por todo apoio.

À Sandra pela grande força e ajuda em todos os momentos turbulentos. 


\title{
COMPARAÇÃO DE DOIS MÉTODOS DE OBTENÇÃO CELULAR PARA CULTURA PRIMÁRIA DE QUERATINÓCITOS BUCAIS HUMANOS
}

\author{
Maria Fátima Guarizo Klingbeil
}

\begin{abstract}
RESUMO
Freqüentemente as condutas terapêuticas utilizadas no tratamento de patologias bucais são cirúrgicas, resultando em falhas de continuidade da mucosa bucal. A possibilidade de obtenção de epitélios transplantáveis, a partir do cultivo in vitro de células da mucosa bucal, abre novas perspectivas de utilização, não se restringindo somente ao seu local de origem, ou seja, a boca, mas também como material de reconstrução para outras regiões, tais como: uretra, córnea, superfície ocular e epitélio córneo-limbal. Os métodos utilizados para a obtenção dessas células ainda são controversos na literatura. Neste sentido, avaliamos e comparamos a eficiência de dois métodos, enzimático e explante, para a obtenção de queratinócitos de mucosa bucal humana. Os fragmentos utilizados para a obtenção dessas células foram obtidos durante procedimentos cirúrgicos de pacientes voluntários saudáveis. Os queratinócitos foram cultivados sobre uma camada de sustentação, feeder-layer, confeccionada com fibroblastos murinos irradiados (3T3 - Swiss albino). Neste estudo foram comparados: o tempo para a obtenção dos queratinócitos, o rendimento obtido entre os dois métodos, a duração da vida útil em cultura, a capacidade que estas células tiveram em formar um epitélio in vitro e a morfologia dos mesmos. Os resultados obtidos, na avaliação dos dois métodos, comprovaram a possibilidade de obtenção dos queratinócitos, a partir de um pequeno fragmento bucal, porém pode-se verificar que existem vantagens e restrições peculiares a cada um dos métodos estudados.
\end{abstract}




\title{
THE COMPARISON OF TWO METHODS TO OBTAIN HUMAN ORAL KERATINOCYTES IN PRIMARY CULTURE
}

\author{
Maria Fátima Guarizo Klingbeil
}

\begin{abstract}
The therapeutic procedures frequently used in oral treatments for the pathological diseases are surgical, resulting in failures of the mucosal continuity. The possibility to obtain transplantable oral epithelia from an in vitro cell culture opens new utilization perspectives not only to where it comes from, but also as a reconstructive matherial for other parts of the human body, such as: urethra, epithelia corneo-limbal, cornea, ocular surface. Many researchers still use controversial methods for obtaining cells. It was therefore evaluated and compared the efficiency in both methods: enzimatic and direct explant to obtain oral keratinocytes from human oral mucosa. Fragments of intra oral epithelial tissues from healthy human subjects, undergoing dental surgeries, were donated to the research project. The keratinocytes were cultivated over a feeder-layer from a previously irradiated 3T3 Swiss albino fibroblasts. In this study it was compared the time needed in the cell obtaintion, the best cell amount between both methods, the life-span, the cell capacity to form an in vitro epithelia and its morphologic structure. The results in the accessment of both methods have shown the possibility to obtain keratinocytes from a small oral fragment, but at the same time we may verify the advantages and peculiar restrictions for each one of both analyzed methods.
\end{abstract}




\section{LISTA DE ABREVIAÇÕES E SIGLAS}

- CNEN/SP- Comissão Nacional de Energia Nuclear/ São Paulo.

- CNS - Conselho Nacional de Saúde

- DMEM - Dulbecco's Modified Eagel's Medium.

- D10 - Nomenclatura adotada em nossos laboratórios para o meio de cultura DMEM acrescido de $10 \%$ de soro animal

- IPEN - Instituto de Pesquisas Energéticas e Nucleares.

- EDTA - ácido etilenodiaminotetracético

- EGF - Epidermal Growth Factor

- FOUSP - Faculdade de Odontologia da Faculdade de São Paulo.

- Ham's F12, Meio de Ham

- K-: meio de cultura próprio para cultivo de queratinócitos, isento de EGF.

- $\mathrm{K}+$ : meio de cultura próprio para cultivo de queratinócitos, acrescido de EGF.

- K-SFM - Keratinocyte serum free medium

- USP - Universidade de São Paulo.

- 3T3-Swiss albino - fibroblastos murinos 


\section{SUMÁRIO}

Página

1. INTRODUÇÃO

2. OBJETIVO

3. CONSIDERAÇÕES GERAIS 15

3.1 A mucosa bucal $\quad 15$

3.1.1.Aspectos morfofuncionais da mucosa bucal 18

3.2 Tipos de epitélio da mucosa bucal 18

3.2.1 Epitélio escamoso estratificado não queratinizado 19

3.2.2. Epitélio escamoso estratificado ortoqueratinizado 21

3.2.3. Epitélio escamoso estratificado paraqueratinizado 22

3.3. Características do epitélio estratificado da mucosa bucal 24

3.4 Componentes estruturais básicos 25

3.4.1. Queratina 25

3.4.2. Queratoialina 27

3.4.3. Tonofilamentos $\quad 28$

3.4.4. Junções Celulares $\quad 30$

3.4.5. Membrana Basal 33

3.5. Ciclo celular 36

3.6. Influência da idade no desenvolvimento da mucosa bucal 37

3.7. Aspéctos de cultivo celular 38

3.7.1. Métodos de obtenção celular 38

3.7.1.1. Método Enzimático $\quad 39$

3.7.1.2. Método do Explante $\quad 39$

3.8. Camada de Sustentação ou Feeder Layer 40

3.9. Eficiência de Formação de Colônias (EFC) 41

3.10. Determinação do tempo de vida celular em cultura (life-span) 41

3.11. Hormônios adicionados ao meio de cultura para queratinócitos 42

3.12. Cultura de queratinócitos em alta densidade 44

3.13. Cultura de queratinócitos em meio de cultura isento de soro animal (KSFM)

3.14. Análise histológica 44

4. MATERIAIS E MÉTODOS

$\begin{array}{ll}\text { MATERIAIS } & 45\end{array}$

Fluxograma de Trabalho $1 \quad 47$

Fluxograma de Trabalho $2 \quad 48$

MÉTODOS $\quad 49$ 
4.1. Preparo do material

4.2. Métodos empregados $\quad 50$

4.2.1. Método Enzimático $\quad 50$

4.2.2. Método do explante

4.3. Propagação celular 53

4.3.1. Estabelecimento da camada de sustentação 53

4.3.1.1. Cultivo dos fibroblastos 53

4.3.1.2. Preparação da camada de sustentação 53

4.3.2. Propagação dos queratinócitos sobre camada de sustentação (feeder layer) $\quad 54$

4.3.3 Cultivo dos queratinócitos em alta densidade 54

4.3.4. Cultivo dos queratinócitos com meio de cultura isento de soro fetal bovino (K-SFM)

4.4. Eficiência de formação de colônias

4.4.1. Cultura das células $\quad 55$

4.4.2 Ensaio com corante não vital 55

4.5. Determinação do tempo de vida celular (life-span) 56

4.6. Confecção dos epitélios 56

4.7. Preparação das lâminas para análise histológica dos epitélios $\quad 57$

4.8. Análise estatística dos dados obtidos 58

5. RESULTADOS 59

5.1 Tamanho dos fragmentos $\quad 59$

5.2. Resultados obtidos a partir da primeira colheita de queratinócitos $\quad 60$

$\begin{array}{ll}\text { 5.2.1 Morfologia da P0 } & 60\end{array}$

5.2.2. Tempo necessário para a obtenção da primeira colheita dos queratinócitos

5.2.3. Rendimento celular inicial para a primeira colheita dos queratinócitos

5.3. Eficiência de formação de colônias (EFC)

5.3.1. Eficiência de formação de colônias (EFC) da primeira passagem 65

5.3.2. Evolução de células clonogênicas $\quad 67$

5.4 Tempo de vida celular (life-span) comparativo $\quad 70$

5.5. Tempo de vida celular resultante de cultivo realizado em alta densidade

5.5.1 Cultivo de queratinócitos em alta densidade com meio K+ $\quad 83$

5.5.2 Cultivo de queratinócitos em alta densidade com meio K-SFM 86

$\begin{array}{ll}\text { 5.6. Confecção dos epitélios } & 87\end{array}$

5.7. Análise histológica dos epitélios cultivados 90

6. DISCUSSÃO $\quad 92$

$\begin{array}{lr}\text { 7. CONCLUSÕES } & 104\end{array}$

APÊNDICE A Questionário informativo 105

APÊNDICE B Porcentagem de colônias em desenvolvimento e colônias abortivas de cada voluntários para cada método 106 APÊNDICE C Quantidade de colônias totais de cada voluntário para cada método 
ANEXO A Aprovação do Comitê de Ética do IPEN

ANEXO B Termo de consentimento pós informação proposto pelo IPEN 111

ANEXO C Instrumento de doação de tecido bucal proposto pela FOUSP 113

ANEXO D Instrumento de doação de tecido bucal proposto pela FOUSP

(cirurgiões dentistas)

REFERÊNCIAS BIBLIOGRÁFICAS 


\section{INTRODUÇÃO}

A complexidade estrutural e funcional da boca faz com que sejam ali observadas, com freqüência, patologias com múltiplas manifestações podendo ter origem congênita ou decorrer de erros genéticos $[1,76]$.

Como exemplos daquelas de origem congênita, podemos citar: defeitos dos lábios, (lábio leporino, depressões, cistos e fístulas do lábio inferior), anomalias do palato, (fenda palatina, torus palatino), anomalias da úvula e anomalias da língua. Deve-se lembrar que, muitas dessas anomalias estão relacionadas a determinadas síndromes.

Decorrente de erros genéticos temos como exemplos alterações da mucosa, tais como: hipo pigmentação, alteração da queratinização, hiperplasias, aplasias, atrofias e doenças bolhosas, doenças da língua, alterações do tecido conjuntivo elástico, alterações de base neurocutânea, patologias hereditárias, neoplasias, doenças hematológicas, anomalias vasculares e nevus [1, 56].

Freqüentemente as condutas terapêuticas utilizadas no tratamento de patologias bucais são cirúrgicas, resultando em falhas, maiores ou menores, da continuidade da mucosa bucal. Conseqüentemente, há a necessidade de oclusão dos defeitos da mucosa bucal, que pode ocorrer pela re-epitelização espontânea a ser realizado pelo transplante de tecidos, inclusive pela utilização de retalho microcirúrgico cutâneo ou mucocutâneo [58, 67, 97].

Embora todas as técnicas mencionadas possuam vantagens e limitações, a opção deve ser avaliada para cada caso. Uma proposta bastante comum é o enxerto autólogo de pele espessa ou de mucosa palatal. O enxerto de pele é bem tolerado dentro da boca, porém evoluindo com diferenças clínicas que podem ser nitidamente observadas, tais como a diferença em relação à cor em redor, a maior descamação e mesmo, pelo crescimento ocasional de pêlos. A morbidade associada à cicatrização da área cutânea doadora, particularmente em idosos, deve também ser considerada.

Enxertos da mucosa bucal são avaliados como mais apropriados porque possuem características similares da área receptora. Como por exemplo, a mucosa do palato duro pode ser aplicada com sucesso na vestibuloplastia, 
entretanto a limitação da área doadora é a grande desvantagem desta alternativa [15].

Em 1975, Rheinwald e Green [78] publicaram método que descreve o cultivo de queratinócitos in vitro, conformando epitélios transplantáveis. Esses autores utilizaram fibroblastos de camundongo modificados (3T3 Swiss albino), previamente irradiados, formando uma camada de sustentação (Feeder Layer). Esses mesmos autores, a partir de 1977, contribuíram mais uma vez para o aprimoramento das condições de cultivo dessas células, introduzindo um polipeptídeo, EGF (fator de crescimento epidérmico) ao meio de cultura [79]. Isto tornou possível o cultivo dos queratinócitos com rendimento celular superior e por um período de tempo mais extenso do que o período atingido anteriormente [78, 79]. A possibilidade de obtenção de um número maior de epitélios transplantáveis abre novas perspectivas de uso, incluindo o tratamento de pessoas com perdas extensa de pele, terapia gênica e outros [15, 28, 40, 42, 45, 53, 63].

Transplante de epitélio cultivado vem sendo utilizado com sucesso desde 1980, como procedimento definitivo para oclusão de feridas em queimaduras de terceiro grau presentes em grandes áreas do corpo. Estudos em longo prazo sobre a evolução do tecido cultivado transplantado foram realizados, mostrando, aos cinco anos pós transplante, presença e características histológicas normais. Neste momento registra-se nível maior de organização do tecido conjuntivo sob as áreas transplantadas, quando comparada com áreas tratadas com técnicas mais tradicionais de transplantes, exemplo: enxertos de espessura parciais [29].

Resultados interessantes passam a ser obtidos a partir do desenvolvimento da cultura in vitro de queratinócitos da mucosa bucal para transplante como enxertos $[15,55,57,75,90,91,95,96,97]$.

O transplante do epitélio bucal cultivado, obtido a partir das células retiradas de um pequeno fragmento intraoral não fica restrito unicamente ao transplante isótipo. Suas características peculiares permitem servir de instrumento na utilização como material de transplante em outros tipos de reconstruções, a saber: uretra [9], córnea, para superfície ocular [68], epitélio córneo-limbal [70]. 
Graças às condições ideais de cultivo in vitro [11, 51], onde essas células podem proliferar como em seu organismo de origem, torna-se possível o transplante de forma autógena desses queratinócitos [28, 29, 33].

O cultivo das células de mucosa nos permite ainda estudos da função celular normal e dos mecanismos celulares de sinalização, presentes nas estruturas celulares normais [106].

Diante das vantagens oferecidas pela disponibilidade dessas células em cultura $[45,53,63,106]$, acima descrito, fica evidente que se estabeleçam métodos de cultivo eficientes para o cultivo de queratinócitos bucais [106].

Dentre as preocupações quanto ao cultivo, destaca-se a obtenção de grande número de células clonogênicas, com alto rendimento. Estes cuidados são necessários, pois o tamanho da área a ser retirada dentro do meio bucal será sempre reduzido, proporcionando pequenos fragmentos para a extração celular.

Em 1910 foi descrito por Carrel e Burrows um método de extração de células epiteliais, denominado explante [22], o qual vem sendo utilizado até os dias de hoje [57]. As células do fragmento inicial, previamente aderido à placa de cultivo, migram para fora do tecido (direção centrífuga) a partir da periferia do fragmento, se aderindo e se multiplicando sobre a placa de cultura [22].

Em 1952, Billingham e Reynolds, iniciaram um método de dissociação das células epiteliais por meio da utilização de uma enzima (tripsina), por este motivo, denominado método enzimático, para a obtenção de células da epiderme (queratinócitos), sem que as mesmas perdessem sua viabilidade e seu potencial de cultivo [12].

Apesar de vários trabalhos publicados sobre o cultivo de queratinócitos empregando os métodos: enzimático ou explante, dúvidas ainda persistem sobre qual seria o método mais indicado para a obtenção do maior número de células clonogênicas, maior rendimento celular e tempo de vida útil em cultura. 


\section{OBJETIVO}

Comparar a eficiência do método enzimático e do método de explante para a obtenção de queratinócitos de mucosa bucal humana, bem como avaliar a vitalidade in vitro destas células quando obtidas pelos diferentes métodos. 


\section{CONSIDERAÇÔES GERAIS}

\subsection{A mucosa bucal}

Vários autores denominam a mucosa, objeto de nosso estudo, de mucosa bucal $[1,9,93]$ enquanto que outros ainda optam pela denominação de mucosa oral [26, 51, 53, 56, 81, 85, 86, 87, 88]. Não havendo diferenças distintas, no presente trabalho optamos em utilizar o termo: mucosa bucal.

A mucosa é um epitélio fino que possui a capacidade de produzir muco [86], freqüentemente referida pelos cirurgiões dentistas, como um tecido mole que circunda seu alvo principal, o dente. Ambas estruturas hospedam as afecções bucais mais freqüentes e comuns, ou seja, a cárie dental e a doença periodontal.

A mucosa bucal funciona como um envoltório para vários tecidos e estruturas, ao mesmo tempo recobrindo e protegendo-os. Além da já mencionada proteção do dente, a lâmina própria e o tecido epitelial mucoso permitem o entremear dos ductos das glândulas salivares em várias regiões [85].

A boca foi muitas vezes descrita como um espelho que reflete a saúde do indivíduo; esta sofre alterações que podem ser interpretadas como sinais indicativos de patologias, tanto locais quanto sistêmicas [88]. Como exemplos de patologias locais, podemos citar: lesões do tipo inflamatório (gengivites e periodontites), distúrbios do desenvolvimento, doenças induzidas por drogas, abscessos e fístulas, lesões físicas, químicas, biológicas e devido a radiações, desordens pigmentadas [56]. Dentre as patologias sistêmicas com manifestação na mucosa bucal, poderíamos citar: doenças auto-imunes, desordens genéticas [56], deficiência de vitaminas e o efeito crônico do álcool ou tabaco [88].

A pele e a mucosa bucal possuem os mesmos componentes estruturais básicos, porém há diferenças marcantes entre as mesmas. Os termos derme e epiderme que são usualmente reservados à pele correspondem na região bucal ao tecido conjuntivo ou lâmina própria e epitélio bucal [87]. Algumas das camadas mais profundas do tecido conjuntivo que compõe a mucosa bucal, possuem uma estrutura mais frouxa, contendo uma rede de vasos sangüíneos, tecido gorduroso e ramos de glândulas produtoras de saliva. Essas camadas formam a sub mucosa [81]. O tecido conjuntivo, por sua vez, é constituído por 
poucas células e uma matriz abundante, promovendo suporte mecânico e nutrientes para o epitélio [54, 88].

Se comparada com a pele, a mucosa bucal é relativamente úmida e macia. Sua cor é o resultado da interação de diversas características tais como, a espessura do epitélio, o grau de queratinização, a pigmentação, e a concentração e distribuição dos vasos sanguíneos, localizados no tecido conjuntivo sob o epitélio [87]. Há ausência de pêlos, glândulas sudoríparas e apenas algumas glândulas sebáceas se encontram presentes [86].

A superfície úmida e a falta de apêndices são as características marcantes que distinguem a mucosa bucal e a do esôfago, da pele. Enquanto a pele contém numerosos folículos e glândulas sebáceas e sudoríparas, o componente glandular da mucosa bucal e do esôfago, é representado primeiramente pelas glândulas salivares menores. Essas glândulas estão concentradas na submucosa, e suas secreções alcançam a superfície da mucosa via ductos salivares menores [88].

Para que um epitélio mantenha sua integridade estrutural, este se utiliza o processo de renovação celular contínuo, no qual as células das camadas mais profundas, produzidas por divisões mitóticas, migram para a superfície, substituindo as células descamadas [99]. Pode-se, entretanto, considerar que as células epiteliais consistem em duas populações funcionais diferentes: uma população progenitora (cuja função é dividir e fornecer novas células) e uma população em maturação (cujas células sofrem o processo de maturação e diferenciação) [93]. Essas células que compõem a população progenitora, denominados de queratinócitos proliferativos, também recebem a denominação de células tronco epiteliais [60].

O epitélio mucoso por ser constantemente renovado por células totipotentes da camada basal é muito bem adaptado para proteger as estruturas subjacentes dos estímulos agressivos de ordem química e mecânica [54, 88].

Assim como a pele, a mucosa bucal possui diversas camadas de células agrupadas entre si, notando-se, em algumas regiões, uma barreira formada por uma camada com expressão de queratina, em sua camada mais superficial [54]. 
Comparando a estrutura da pele com a estrutura da mucosa bucal e da mucosa do trato gastrintestinal, uma série de diferenças começa a emergir em termos de organização, refletindo desta maneira as diferentes funções de cada regiões. A forração do estômago e dos intestinos (fino e grosso) é constituída por um epitélio simples composto somente por uma camada celular, a qual facilita a absorção por meio do tecido. Já a pele, a boca, o esôfago, a vulva, a vagina e a porção vaginal do colo uterino têm como característica peculiar possuírem epitélios escamosos estratificados, compostos por múltiplas camadas de células. Além de mostrar vários padrões de diferenciação e maturação, desde a camada mais profunda até a mais superficial, esses epitélios são responsáveis por recobrir a superfície de vários órgãos que estão em contato direto com o meio externo [54, 88].

A pele exerce a função de barreira entre o organismo e o, potencialmente hostil, meio ambiente que o circunda, sendo considerada a maior fonte de informação e de adaptação ao meio ambiente que o ser humano possui. Assim, protege os tecidos mais profundos de esforços mecânicos e radiações solares, igualmente prevenindo-os da penetração de microorganismos e substâncias tóxicas e de desidratação. A mucosa bucal apesar de possuir a mesma origem embriológica e mostrar similaridade em sua morfologia, exerce um menor papel como barreira protetora. Existe um estímulo mecânico constante, devido ao ato mastigatório, entretanto esta está raramente exposta à radiação solar. O grau de permeabilidade da mucosa bucal é bem maior quando comparada com qualquer região da pele, porém essa afirmação pode gerar confusão, pois as glândulas salivares criam uma umidade superficial constante da mucosa, aparentemente sem provocar a inundação dos tecidos. Na direção oposta, a perda de fluído intersticial para o meio exterior parece não ocorrer, devido a esta umidade presente na mucosa. Assim a mesma não é considerada simplesmente uma membrana permeável de revestimento, mas possui funções de proteção similares as da pele, além de acentuada função imunológica, apresentando seu local de maior fragilidade na junção dento-gengival, quando a continuidade da superfície do epitélio é interrompida pela presença do dente [86]. 


\subsubsection{Aspectos morfofuncionais da mucosa bucal}

Os vários componentes da boca são recobertos por mucosas diferentes tanto em sua estrutura quanto em sua função. Estas podem ser divididas em três principais tipos:

Mucosa especializada - recobre o dorso da língua e o vermelhão dos lábios, sendo responsável pela sensibilidade térmica, gustativa e sensorial, podendo ser também chamada de mucosa sensorial.

Mucosa mastigatória: - recobre a gengiva e reveste o palato duro.

Mucosa de revestimento - reveste outras porções da língua e o restante da boca $[10,26,81,88,93]$.

Collins e Dawes [apud 86] estimaram que a área ocupada por cada tipo de mucosa pode ser descrita aproximadamente como sendo:

$$
\begin{aligned}
& \text { 25\% - mucosa especializada (dorso da língua) } \\
& \text { 15\% - mucosa mastigatória } \\
& 60 \% \text { - mucosa de revestimento [88] }
\end{aligned}
$$

\subsection{Tipos de epitélio da mucosa bucal}

Em diferentes regiões, a mucosa bucal mostra-se adaptada às demandas e possui para cada função mecanismos diferentes. Por exemplo, a mucosa mastigatória possui epitélio escamoso estratificado firmemente adaptado e conectado ao tecido conjuntivo adjacente e às fibras colágenas pertencentes ao mesmo tecido conjuntivo; já o epitélio da mucosa de revestimento, é não queratinizado, suportado por um tecido conjuntivo mais elástico e flexível $[10,26$, 81, 88, 93].

As células epiteliais da mucosa bucal são denominadas queratinócitos, por possuírem a capacidade de produzir queratina de forma natural no próprio tecido queratinizado, como também são capazes de produzi-la em tecido não queratinizado, quando este sofre qualquer tipo de estímulo traumático. Outras células estão presentes no epitélio bucal, incluindo os melanócitos, células de 
Langerhans, células de Merkel [10, 81] e células de Granstein [10], porém em menor quantidade. Ainda temos os linfócitos, a maioria deles, os linfócitos-T, dentre os quais os T-supressores, duas vezes mais abundantes do que os Tauxiliares [81].

De acordo com a presença ou não de queratina, são encontrados três tipos de epitélio dentro da boca:

$$
\begin{aligned}
& \text { Epitélio não queratinizado. } \\
& \text { Epitélio ortoqueratinizado. } \\
& \text { Epitélio paraqueratinizado }
\end{aligned}
$$

\subsubsection{Epitélio escamoso estratificado não queratinizado.}

Esse epitélio é notadamente encontrado na mucosa de revestimento labial, bucal e alveolar, recobrindo o assoalho da boca, a superfície do ventre da língua e o palato mole $[10,26]$. Esse tecido possui epitélio histologicamente semelhante entre si, embora sua aparência possa ser variada nas diferentes áreas (vide FIG.1 A) [10, 26].

O epitélio não queratinizado é a forma mais comum de epitélio presente dentro da boca, possuindo pelo menos três camadas distintas: Enquanto os estratos basal e espinhoso estão presentes, os estratos granuloso e córneo estão ausentes, pois ambas camadas são substituídas respectivamente pelos estratos intermediário e superficial [10]. Segundo Squier, este critério de divisão não passa de uma tendência arbitrária [10, 26, 81, 87].

O estrato basal, o mais profundo das camadas, denominado também de camada basal, situa-se acima da lâmina própria. É constituído por uma paliçada de células epiteliais cubóides que recobre a membrana basal, situado por sua vez acima da lâmina própria. Em 1963, Midgely e Pierce demonstraram em estudos imunoistoquímicos a presença de antígenos da membrana basal nas células epiteliais [apud 85]. A marcação de anticorpos à base de ferritina, permitiu a conclusão que o material da lâmina basal é produzido pelo retículo endoplasmático das células basais. Estes estudos foram realizados em 1963, por Pierce, Midgely e Sri Ram [apud 85], sendo hoje realizados pela utilização de várias citoqueratinas específicas. A sugestão da contribuição do epitélio para a 
formação da membrana basal foi substanciada por estudos radioautográficos, onde $\mathrm{H}^{3}$-prolina foi primeiramente observada em células epiteliais e posteriormente na região da membrana basal. Isto foi concluído segundo estudos realizados em 1963 por Hay e Revel [apud 85]. A camada basal sintetiza e secreta, produzindo assim a lâmina basal da membrana basal $[10,26]$. Com base nestes estudos, alguns dos componentes da membrana basal parecem possuir origem epitelial [85].

A camada basal, constituída pelas células basais, também é considerada germinativa porque a mitose das células epiteliais "mães" ocorre a este nível. Essas células quando migram, perdem a capacidade de sofrer mitose $[10,26]$.

Cada célula mãe, localizada na camada basal do epitélio, se duplica gerando duas células filhas. O compartimento progenitor não é homogêneo, mas consiste de duas sub-populações de células funcionalmente distintas. Uma pequena população de células progenitoras tem ciclo reprodutivo muito lento e são consideradas representantes das células tronco, tendo a função de produzir células basais e reter o potencial proliferativo do tecido. Ao se dividir com pouca freqüência, as células tronco epiteliais são importantes para a preservação da informação genética do tecido, uma vez que o DNA é bastante vulnerável e sujeito à modificações durante a fase mitótica [60].

Após a divisão celular, cada célula filha retorna ao ciclo celular ou segue em direção à diferenciação. A decisão depende de fatores como: cálcio extracelular, presença de forbo esteres, ácido retinóico e vitamina D3. As células da camada basal são interligadas por adesão focal contendo integrinas e a diferenciação envolve migração com perda de expressão dessas integrinas e aumento das caderinas, mediadoras de adesão, via junção intercelular do tipo gap ou tight ou via desmossomos. Pela posição dessas células em relação à anatomia estrutural de certos tecidos, as mesmas não são morfologicamente detectáveis em muitas áreas, como ocorre na pele e no epitélio da mucosa oral [88].

A camada de células superficiais à camada de células basais do epitélio não queratinizado é chamada de espinhosa. É assim denominada pela característica do formato elíptico de suas células, possuindo projeções em forma de espinhos. A mesma é composta por células maiores sobrepostas, de formato 
poliédrico, com aparência mais alargada e abaulada com relação às células basais, uma vez que elas possuem maior quantidade de fluido dentro de seu citoplasma. Esta camada intermediária é responsável pela espessura do epitélio não queratinizado $[10,26,87]$.

A camada mais superficial do epitélio não queratinizado é denominada de superficial ou stratum superficial. É muito difícil estabelecer exatamente a transição entre a camada superficial e a camada intermediária em cortes histológicos, uma vez que a camada superficial mostra igualmente células epiteliais grandes, alargadas, de formato poliédrico, amontoadas, com seu exterior planificado e achatadas. As células desta camada vão se desprendendo e descamando conforme envelhecem e morrem, como parte do processo de renovação do tecido. Conseqüentemente a maturação das células epiteliais é observada pelo aumento do seu tamanho [86], por sua senescência e migração para a superfície do tecido $[10,26,39]$. As mudanças são conseqüentes à síntese de um maior número de proteínas estruturais, pelo aparecimento de mais organelas e pela secreção adicional de material intercelular. Ao migrar, o aumento resultante do tamanho dessas células é mais acentuado do que no epitélio queratinizado [87].

Em 1981, como resultado de estudos quantitativos de tecido, Schroeder propôs uma outra subdivisão para o epitélio não queratinizado. Retendo os termos estrato basal e supra-basal, este autor sugeriu os termos: a) estrato filamentoso, com o objetivo de descrever a grande quantidade de filamentos soltos que iniciam seu aparecimento nesta camada, para a camada correspondente à camada espinhosa no epitélio queratinizado, b) estrato disdento, situado superficialmente ao estrato filamentoso, representado pela maioria das células maduras do epitélio não queratinizado, as quais ocupam por volta de mais de um terço da espessura deste epitélio [26, 87].

\subsubsection{Epitélio escamoso estratificado ortoqueratinizado}

Esse epitélio apresenta a queratinização das células epiteliais em suas camadas mais superficiais. O epitélio ortoqueratinizado é a forma de epitélio mais comum encontrada na mucosa mastigatória. Também compõe a mucosa especializada da papila lingual da superfície dorsal da língua. As células desse tecido, na medida em que migram para a superfície durante sua maturação, 
produzem queratina, que reflete uma diferença tanto em seu aspecto como em sua fisiologia (vide FIG. 1 B) [10].

Assim como o epitélio não queratinizado, o epitélio ortoqueratinizado possui uma camada basal, composta por uma paliçada de células que sofrem mitose. Essa camada também produz a lâmina basal da membrana basal subjacente.

O epitélio ortoqueratinizado possui três camadas superficiais à camada basal. Imediatamente acima da camada basal se encontra a camada espinhosa, ou stratum espinhoso. Estas células de formato elíptico possuem, como características, projeções em forma de espinhos e são responsáveis pela espessura do epitélio ortoqueratinizado [10].

Superficialmente à camada espinhosa se encontra a camada granulosa, ou stratum granuloso, com três a cinco células de espessura, muito rara em boca. Essas células achatadas, enquanto nucleadas, contêm em seu citoplasma grânulos de queratoialina, os quais costumam ser observados como manchas ou pontos escuros no citoplasma.

Finalmente a camada mais superficial do epitélio ortoqueratinizado é o stratum corneum (estrato córneo), camada queratinizada de espessura variável, segundo a região. As células mais superficiais são planas, desprovidas de núcleo, e seu citoplasma preenchido com queratina; estas são denominadas escamas e mostram um maior achatamento, desprendendo-se facilmente, pois elas não são viáveis [10].

\subsubsection{Epitélio escamoso estratificado paraqueratinizado}

Acredita-se que o epitélio paraqueratinizado é uma forma imatura de epitélio ortoqueratinizado. Enquanto que a presença de paraqueratinização na pele é considerada um sinal patológico, na boca sua presença está associada a uma característica histológica de saúde. Esta é, provavelmente, uma das únicas características histológicas que difere a mucosa bucal da pele [10].

Este epitélio está associado à gengiva inserida e parte da mucosa mastigatória [10]. Por exemplo, em algumas regiões do palato duro o epitélio ortoqueratinizado se diferencia em epitélio paraqueratinizado (vide FIG.1 C). Este tipo de epitélio possui as camadas semelhantes ao epitélio ortoqueratinizado: 
camada basal, camada espinhosa, camada granulosa e camada de queratina. A camada granulosa pode ser indistinguível da espinhosa ou estar ausente [10]. Os grânulos de queratoialina, microgrânulos e outras organelas citoplasmáticas estão ausentes no estrato córneo de ambos epitélios. Em regiões de epitélio ortoqueratinizado, a maioria das células do estrato córneo está preenchida por um material eletro-denso homogêneo, enquanto que em regiões de epitélio paraqueratinizado a estrutura filamentosa citoplasmática ainda se mantém reconhecível na maioria das células e o núcleo ainda persiste [84].

Silverman (1971) [apud 24], ainda descreve como características desse tipo de epitélio a retenção de núcleos picnóticos, o reconhecimento de filamentos e a presença de gotas lipídicas na superfície dessas células epiteliais. As células queratinizadas da gengiva humana apresentam um padrão de características de grupos similares de filamentos do epitélio ortoqueratinizado do palato duro, invariavelmente contém restos de núcleos remanescentes ou núcleos picnóticos, além de numerosas gotas lipídicas. Isso nos leva a crer que a paraqueratinização ocorra com freqüência na gengiva humana [24]. A principal diferença entre o epitélio paraqueratinizado e o epitélio ortoqueratinizado está nas células mais superficiais da camada de queratina. No epitélio paraqueratinizado estas células ainda possuem seus núcleos, como descrito anteriormente. Estudos têm demonstrado que mesmo que essas células epiteliais continuem com seus núcleos, elas possivelmente não estarão viáveis por muito tempo, o que justifica a sua descamação [10].

A seguir na FIG. 1 imagens fotográficas dos tipos de epitélio bucal humano. 

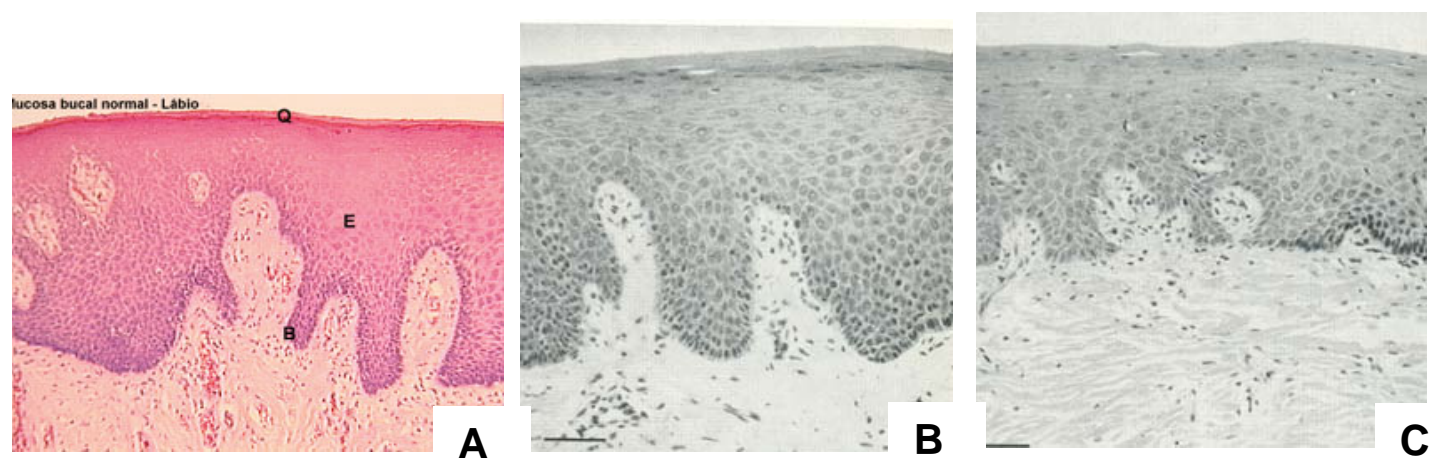

FIGURA 1 - Imagens fotográficas do epitélio bucal humano: A) epitélio não queratinizado da mucosa de revestimento (B- camada basal, E- camada espinhosa, Qcamada superficial) (aumento de 40 vezes) [FOUSP], B) epitélio ortoqueratinizado do palato, C) epitélio paraqueratinizado do palato. Marca representa 100 $\mu$ [84].

\subsection{Características do epitélio estratificado da mucosa bucal}

Uma das principais características do epitélio estratificado é a progressiva quantidade de proteínas estruturais que se acumula durante 0 processo de diferenciação celular. Essas proteínas em sua maioria estão representadas por filamentos, os quais podem ser visualizados em todas as camadas celulares. No epitélio queratinizado a maioria destes filamentos concentram-se no estrato córneo, onde os mesmos podem ser encontrados embebidos em uma matriz, sendo esta denominada de grânulos de queratoialina da camada granular, estruturas que igualmente possuem proteínas. Os tecidos queratinizados são característicos pela insolubilidade em: água, soluções tampão, ácidos diluídos, bases e solventes orgânicos. As proteínas estruturais desse tecido mostram um grande grau de resistência à ação da pepsina ou da tripsina. Somente tratamentos drásticos, como: exposição à ação de fortes ácidos ou bases, agentes redutores, agentes oxidantes ou soluções concentradas de uréia, podem resultar em dissoluções totais ou parciais. Assim como é sabido que a membrana celular dos queratinócitos pertencentes à camada queratinizada é resistente à digestão de várias enzimas, as quais, os tonofilamentos, os grânulos de queratoialina e os desmossomos são suscetíveis. A sua resistência provavelmente se deve em parte pela alta concentração de enxofre. A resistência das proteínas estruturais intracelulares e da membrana celular desempenha papel importante para o epitélio queratinizado, capacitando-o à ação protetora superficial $[48,85]$. 


\subsection{Componentes estruturais básicos}

\subsubsection{Queratina}

Termo derivado do grego "keratos", para denominar o chifre e a superfície externa da pele, ou seja, estrato córneo ou camada córnea. Assim, o termo queratina é freqüentemente utilizado para descrever o material presente na pele superficial, cabelo, unha, escama, pena. Pouco se conhece sobre os componentes proteicos dessa estrutura. A queratina faz parte da família de proteínas predominantes do citoesqueleto em todos os epitélios [71], sendo 30\% a 50\% do total dos componentes do citoesqueleto no epitélio bucal [43].

Muitas das proteínas estruturais produzidas pelo epitélio escamoso são essenciais para a integridade do tecido. Em adição, muitas moléculas reguladoras como os fatores de crescimento e transcrição são importantes para o desenvolvimento e função celular normal [17, 35, 72].

Sabemos que a queratina pertence a uma classe de proteínas, chamadas de fibrosas. Compondo o grupo "KMEF", ou seja: queratina da lã (Wool Keratin), miosina do músculo, epidermina da camada celular da epiderme e fibrinogênio do plasma sanguíneo. Rudall descreve em seu trabalho de 1952 [apud 84], a hipótese de que as tonofibrilas das camadas celulares são os precursores do material da camada córnea (stratum corneum) [85].

As queratinas são consideradas como os principais produtos de diferenciação dos queratinócitos e um importante constituinte bioquímico dos tonofilamentos [35].

A queratina é dividida em dois sub grupos: $\alpha$ e $\beta$. O sub-grupo alfa está presente nas células de mamíferos e ambos, os sub-grupos alfa e beta, nos répteis e aves. As queratinas da epiderme humana e presumivelmente da boca são classificadas como pertencentes ao sub-grupo alfa; a maioria dos trabalhos físico-químicos sobre a queratina do sub-grupo alfa foram realizados tendo a queratina presente na lã como fonte de material [85].

As queratinas do grupo $\alpha$ são proteínas citoplasmáticas que pertencem aos filamentos intermediários (IF), super família de proteínas estruturais. As $\alpha$ queratinas estão divididas em dois grupos: tipo I e tipo II, que diferem na seqüência dos aminoácidos e propriedades bioquímicas. São expressas no 
epitélio em forma de pares, ao mesmo tempo pareadas em: uma queratina do tipo I e outra do tipo II, as quais se unem para formar uma variedade de filamentos que se estendem a partir do núcleo até à membrana celular. Esses filamentos funcionam como estruturas de importância constitucional dentro das células epiteliais e são críticos para a manutenção do formato e da viabilidade celular. $\mathrm{Na}$ ausência do par apropriado, desses filamentos de queratina, as moléculas protéicas instáveis se tornam suscetíveis à degradação pelas proteases, enzimas próprias de degradação protéica [71].

Até 2001 tinham sido descritas 30 proteínas de diferentes pesos moleculares, representando as queratinas. As de menor peso molecular estão em torno de 40 kd, como a CK8 e CK18, estas são encontradas no epitélio simples e epitélio glandular. As de peso molecular intermediário são encontradas no epitélio estratificado e as de maior peso molecular, aproximadamente 67 kd, são encontradas em epitélio estratificado queratinizado.

Todo o epitélio bucal estratificado expressa queratina do tipo CK5 e CK14 nas células indiferenciadas da camada basal; diferentes queratinas emergem na camada supra basal, desta vez com células em processo de diferenciação.

O epitélio ortoqueratinizado como do palato contém queratinas CK1 e CK10, porém a gengiva e o epitélio paraqueratinizado do palato contêm queratina CK1 e CK10 ou queratina CK4 e CK13. O epitélio não queratinizado, incluindo o esôfago, contém queratina CK4 e CK13 [87]. O epitélio juncional adjacente à superfície dental, produz ainda um conjunto diferente de queratinas, tais como a do tipo CK2e presente também na epiderme, e CK6, CK16 e CK2p nas camadas mais diferenciadas da superfície da gengiva e do tecido do palato duro [14, 71].

A seguir na FIG. 2, representação esquemática da epiderme e epitélio bucal queratinizado (orto e paraqueratinizado) e epitélio bucal não queratinizado. 
Epiderme, epitélio bucal queratinizado

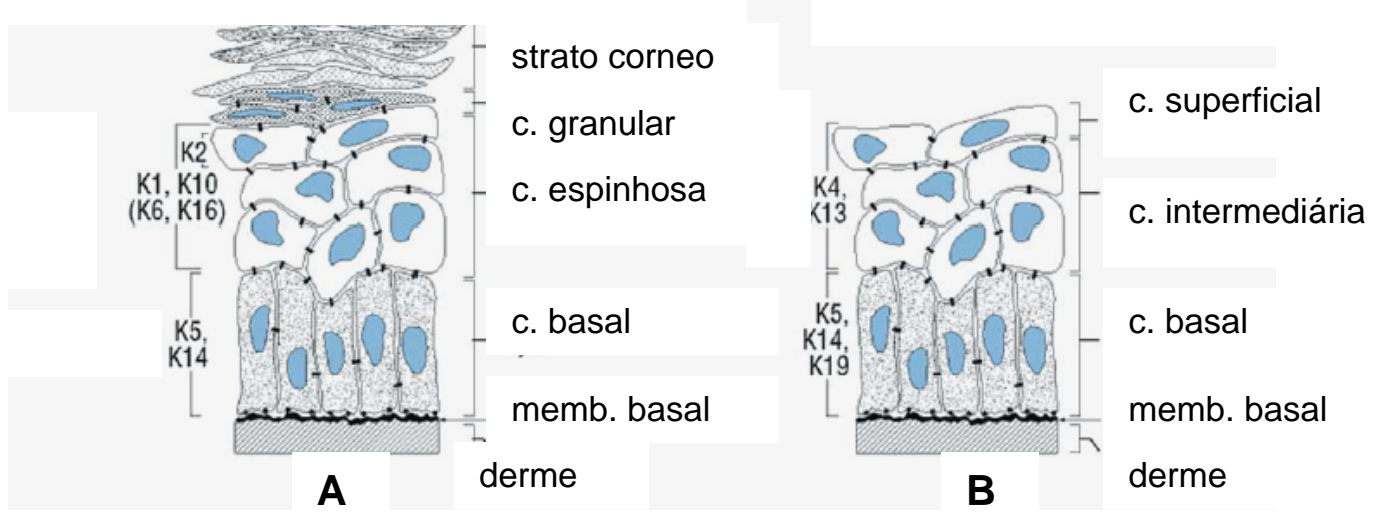

Epitélio bucal não queratinizado

FIGURA 2 - Esquema representativo da epiderme e epitélio bucal: A) epiderme e epitélio bucal orto e paraqueratinizado; B) epitélio bucal não queratinizado [71], modificada pela autora.

\subsubsection{Queratoialina}

Os grânulos de queratoialina são inclusões celulares encontradas nas células do estrato granuloso do epitélio ortoqueratinizado, lembrando que essa camada é bastante pobre ou até mesmo ausente no epitélio paraqueatinizado e no epitélio não queratinizado [26].

Alguns autores consideram que os grânulos de queratoialina da epiderme sejam precursores da matriz que envolve a camada de queratina. Esse conceito pode ser estendido ao epitélio bucal.

Dois tipos diferentes de grânulos de queratoialina estão presentes no epitélio bucal, porém nem sempre estão presentes em todas as regiões do mesmo.

O primeiro tipo é idêntico aos grânulos de queratoialina da camada granular da epiderme. Estes possuem formato irregular, freqüentemente se encontram circundados por ribossomos e são associados aos feixes de tonofilamentos longos e grossos. Diferencialmente da epiderme onde estão presentes em todas as regiões, no epitélio bucal limitam-se unicamente a algumas regiões de ortoqueratinização completa, como por exemplo: na camada granular do palato duro e alguns locais da gengiva. Ainda presentes, em menor quantidade, na região paraqueratinizada do palato duro e gengiva. Esses sempre estarão ausentes no epitélio não queratinizado, assim como nas regiões onde a ortoqueratinização é incompleta. Em regiões com típica camada granular, com 
grânulos do tipo epidérmicos, os tonofilamentos da camada córnea se encontram encravados em uma matriz eletro-opaca [2, 23, 85].

O segundo maior tipo de grânulos de queratoialina é peculiar ao epitélio bucal. Esses são maiores e mais regulares em seu formato do que os do tipo epidérmico, porém igualmente eletro-opacos. Como na epiderme, esses são circundados por ribossomos, entretanto falta a associação com os proeminentes feixes de tonofilamentos, os quais são característicos no tipo epidérmico. Assim, os grânulos típicos encontrados na boca se tornam igualmente característicos pela grande estrutura eletro-opaca presente entre os pálidos e dispersos tonofilamentos. Esses grânulos estão descritos como presentes em todo epitélio bucal, o qual recobre estruturas móveis, ao mesmo tempo em que tonofilamentos estão aleatoriamente dispersos. Seu número parece ser menor em regiões onde o epitélio não é queratinizado [2, 23, 85].

\subsubsection{Tonofilamentos}

Os tonofilamentos são proteínas fibrosas sintetizadas pelos ribossomos, sendo observados como longos filamentos com diâmetro aproximadamente de $8 \mathrm{~nm}$. Estes pertencem a uma classe de filamentos intracelulares, chamados filamentos intermediários, e formam um importante componente estrutural no interior da célula [93]. Os tonofilamentos do epitélio escamoso estratificado não representam somente a principal característica estrutural deste tecido, mas o componente citoplasmático de maior abundância e o maior elemento estrutural. Todos os epitélios estratificados contêm filamentos de composição e dimensões similares (7.5-10 nm de diâmetro), que são os filamentos intermediários. A concentração e a organização desses filamentos fazem parte das características indicativas do tipo de maturação exibida pelo epitélio escamoso estratificado [24]. Os tonofilamentos estão presentes em todas as células do epitélio bucal, tanto no epitélio queratinizado, quanto no não queratinizado [85]. Existem diferenças consideráveis entre o epitélio queratinizado e não queratinizado com relação à concentração e o grau de agregação desses filamentos, situados no citoplasma. Nas células da camada basal de ambos epitélios, essa diferença não é muito aparente e esses filamentos se arranjam formando feixes de tonofibrilas [24], os quais chegam a ocupar cerca de $13 \%$ do volume da camada do tecido [81]. Durante a transição das células da camada 
basal para a camada granular, no epitélio não queratinizado, essas células possuem maior quantidade de tonofilamentos e apresentam um aumento de tamanho mais acentuado, quando comparadas com as células do epitélio queratinizado. Porém no epitélio não queratinizado as células apresentam um ligeiro aumento do volume com relação ao peso, enquanto que no epitélio queratinizado esse volume passa a ter um aumento de menor proporção em relação ao peso $[2,84]$. No epitélio queratinizado o menor aumento do volume em relação ao peso é devido ao firme empacotamento dos tonofilamentos nas células da camada granular, quando comparadas com as células da camada basal. Em contraste, no epitélio não queratinizado as células mostram um aumento de tamanho, enquanto que o aumento da concentração dos tonofilamentos não se torna evidente [84].

Tanto no epitélio queratinizado, como no não queratinizado, o volume dos tonofilamentos parece ter uma distribuição randômica dentro do citoplasma em toda a espessura deste epitélio. Somente alguns tufos estão associados aos desmossomos e hemidesmossomos na camada basal. Esses desmossomos não aumentam muito mais de tamanho, quando comparados com o tamanho que possuem na camada basal, sendo assim esses tonofilamentos associados se mantêm pequenos, em tufos soltos em todas as camadas celulares. Como já anteriormente mencionado, os tonofilamentos no epitélio queratinizado mostram uma formação em tufo, contrastando com o formato dos mesmos no epitélio não queratinizado. Ainda com relação à sua concentração, esta parece aumentada na camada queratinizada, em relação à camada granular, no epitélio queratinizado. Esse aumento ocorre em parte devido ao espaço não ocupado pelo núcleo e organelas, e em parte pelo empacotamento mais compacto desses filamentos. Sendo assim, a diferença na concentração desses filamentos se torna bastante visível e, portanto mais marcante, a este nível. O pouco espaço entre os tonofilamentos, na camada espinhosa do epitélio queratinizado, está correlacionado ao fato de que na transição da camada granular para a camada queratinizada, maior quantidade de água se perdeu, restando, portanto agora uma maior concentração de material seco. No epitélio não queratinizado proporções equivalentes de água e material seco se encontram dispersas no citoplasma [84]. 


\subsubsection{Junções Celulares}

As células de alguns tecidos estão unidas por junções celulares. Estas junções mecânicas possibilitam a união entre as células e entre células e superfícies não celulares.

Por meio destas uniões celulares a membrana destas células se aproxima intimamente sem, entretanto, se tornar aderida por completo. Essas junções, por possuírem aparência de corpos densos, somente permitem ser visualizadas por microscópios de alta resolução. Todo tipo de junção celular envolve um mecanismo de união bastante complexo, o qual é compartilhado entre as membranas das células envolvidas [10].

O epitélio bucal apresenta três tipos diferentes de junção intercelular: desmossomos (macula adherens), junção do tipo gap ou nexus e junção do tipo tight (macula ou zonula occludens) [10, 24, 26, 71].

As junções do tipo gap se encontram presentes com determinada freqüência, enquanto que as junções do tipo tight são encontradas com maior raridade. Esta última ocorre, quando as membranas plasmáticas de duas células adjacentes se encontram fusionadas de tal maneira, que haja muito pouco ou nenhum espaço entre as mesmas, seu aparecimento é limitado às camadas mais superficiais do epitélio bucal, mas não na camada córnea. Justifica-se assim sua rara freqüência [24], especialmente quando comparadas com os desmossomos. Esse tipo de junção epitelial parece possuir uma menor atuação como uma união mecânica, e mais como um selante, capaz de vedar áreas do espaço intercelular em verdadeiros compartimentos separados (vide FIG. 4 A) [87]. As junções gap são observadas acima da camada basal, nunca na camada queratinizada, e estão freqüentemente próximas aos desmossomos. Assim como os desmossomos, estas são representadas por regiões onde as membranas plasmáticas das células adjacentes seguem paralelamente, variando suas distâncias, embora não exista um espaço intercelular especializado. Neste tipo de junção, a superfície mais externa da membrana se encontra separada uniformemente por uma fenda, medindo de 2 a 5 nm, medidas realizadas por Barnett e Szabo, em 1973 [apud 24]. A junção gap parece mais facilitar a comunicação intercelular do que fornecer a adesão celular (vide FIG. 4 B) [24]. 
Os desmossomos, além de mais freqüentes, representam uma das características peculiares do epitélio escamoso estratificado [24], sendo complexos de adesão celular que ligam uma célula epitelial à outra, ou fixam filamentos de queratina à superfície celular [71]. Estes são constituídos por duas regiões intercelulares densas e espessadas (placas de adesão), associadas à face citoplasmática da membrana celular da célula oposta. Nessas placas de adesão estão inseridos feixes de tonofilamentos (vide FIG.4 A e 4 B) [26].

Os desmossomos estão presentes em todo o epitélio e igualmente em outros tecidos especializados, como o miocárdio. Estes consistem em dois grupos principais de proteínas: as caderinas desmossomais e as desmogleinas e desmocolinas que vão até a membrana plasmática e um largo grupo de proteínas que residem na face citoplasmática dos desmossomos (compreendendo a estrutura visível ao microscópio eletrônico conhecida como placa desmossômica ou desmossomal), a qual funciona ligando as proteínas caderinas aos filamentos citoplasmáticos de queratina. As proteínas associadas desta placa citoplasmática incluem as: placoglobinas, desmoplaquinas, placofilinas, envoplaquinas e periplaquinas. Acredita-se que as caderinas desmossomais, como as clássicas caderinas presentes na aderência juncional, sejam responsáveis pela mediação da adesão celular por meio da interação pelo cálcio dependente entre os domínios das proteínas extracelulares as quais ligam umas células às outras. Em adição aos desmossomos, as células epiteliais possuem aderências juncionais, as quais são compostas pelas proteínas presentes na membrana plasmática, como as: E-caderinas e as P-caderinas. Essas proteínas estão ligadas a uma série de proteínas actina do citoesqueleto citoplasmático [71]. Os desmossomos representam a forma de adesão mecânica mais intensa entre as células epiteliais $[24,26]$. Esta afirmação é válida quando se observa o sistema elaborado de placas e filamentos e conseqüentemente a resistência dessas células à separação [24]. Os desmossomos são responsáveis pelo aspecto e conseqüente nomenclatura da camada espinhosa, observados nos cortes histológicos [26]. Num epitélio onde o ritmo de renovação celular é mais lento, as células epiteliais deixam a camada basal e migram para a superfície, atingindo-a em menos de um mês. Isso é possível graças à movimentação independente dessas células, umas por meio das outras. Certamente deve haver um mecanismo constante de união e 
quebra dessas ligações permitindo, portanto essa trajetória. Isso é confirmado ao observar as células em divisão, quando as mesmas apresentam uma menor quantidade de desmossomos do que as células que se encontram em intérfase. Os desmossomos tendem a se desintegrar no momento que essas células atingem a superfície. Ao observar as células epiteliais em cultura, foi constatado que as mesmas quando separadas, sem evidência de desmossomos em suas superfícies e colocadas em contato com as outras células, eram capazes de voltar a formar essas estruturas dentro de 90 minutos [24].

Evidências comprovam a existência de vários tipos ou grupos de desmossomos, os quais mesmo apresentando aparência semelhante em suas estruturas, respondem de maneira diferente a várias substâncias químicas. Desta maneira, os autores: Borysenko e Revel [16], identificaram dois tipos de desmossomos. Um deles pode ser dissociado pela ação da tripsina em concentrações baixas, e outro que não responde à ação da enzima tripsina, pode ser quebrado por sais de ácido etilenodiamino-tetra-acético (EDTA) [54].

Quando as células dos epitélios se apóiam sobre uma membrana não celular, denominada lâmina basal, o bordo em contato com a mesma apresenta estruturas semelhantes aos desmossomos, entretanto denominada agora de hemidesmossomos, por estas não possuírem a metade que pertenceria à outra célula epitelial. Existe um espessamento de uma área limitada do citoplasma da célula basal, adjacente à membrana basal, sob a qual convergem fibrilas citoplasmáticas. Desta vez a membrana basal mostra um ligeiro e discreto espessamento, o qual contém filamentos, agora bastante delgados [54].

A seguir na FIG. 3 está representado o esquema dos três tipos de junções celulares. 


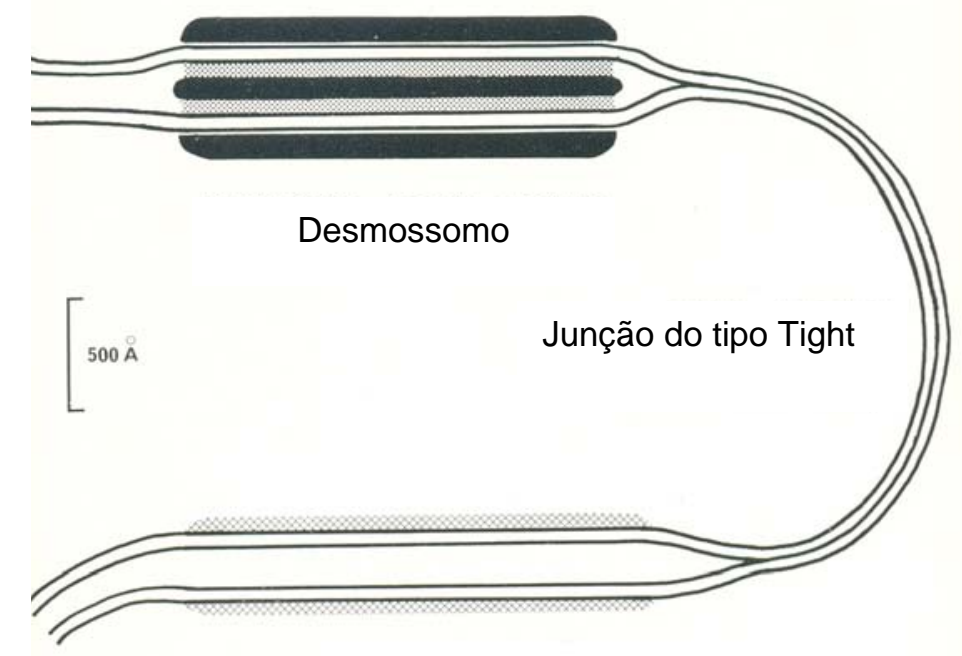

Junção do tipo Gap

FIGURA 3 - Esquema dos três tipos de junções celulares [85], modificada pela autora.

A seguir nas FIG. 4 são mostradas imagens fotográficas das junções celulares.

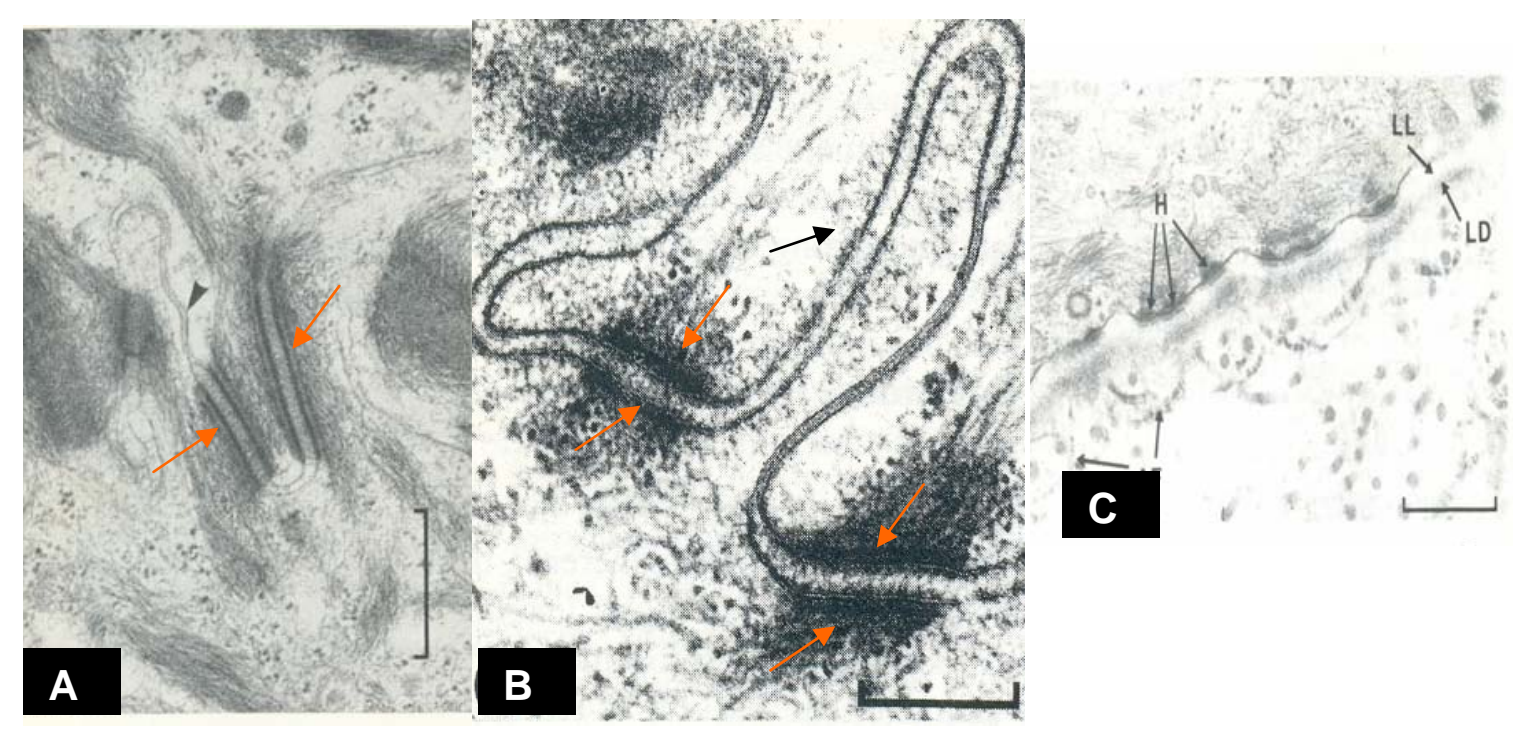

FIGURA 4 - Imagens fotográficas das junções celulares A) dois desmossomos $(\nabla)$ e uma junção do tipo tight ( $<$ )(barra representa $0,5 \mu \mathrm{m}$ ); B) quatro desmossomos $(\swarrow)$ com junções adjacentes do tipo gap $\longrightarrow$ )(barra representa 0,2 $\mu \mathrm{m})$ [86]; C) hemidesmossomos (H), Lâmina lúcida (LL) Fibras de ancoragem (AF), (barra representa $0,5 \mu \mathrm{m})$ [24].

\subsubsection{Membrana Basal}

Membrana basal é o termo utilizado para descrever a camada existente, observada ao microscópio ótico, no local da junção de vários tipos de epitélio com o tecido conjuntivo subjacente [85]. A membrana basal é uma fina 
camada (1-2 $\mu \mathrm{m})$, acelular, sempre localizada entre o epitélio e o tecido conjuntivo em ambos tecidos: pele e mucosa bucal [10, 24]. A porção superficial da membrana basal é denominada lâmina basal e é produzida pelo epitélio [10, 20, 24]. Uma membrana intermediária ou um espessamento intermediário está geralmente presente, localizada intimamente às células basais, entre a membrana plasmática destas e a lâmina basal da membrana basal. Esse material, de natureza densa e estrutura fibrilar, completa a composição dos hemidesmossomos [54]. Esta parece ser constituída por finos filamentos e material granular, se tornando um pouco mais espessa em contato com os hemidesmossomos [85]. A lâmina basal é constituída ainda por duas outras camadas: a lâmina lúcida, uma camada próxima ao epitélio e a lâmina densa, como sugere a nomenclatura, uma camada mais densa próxima ao tecido conjuntivo [10, 24]. A lâmina lúcida parece separar a lâmina basal da membrana plasmática das células basais subjacentes. Esta contém um material difuso de pouca densidade eletrônica e finos filamentos, os quais parecem passar entre a lâmina basal e a membrana plasmática das células basais adjacentes, se tornando mais concentrados ao contato com os hemidesmossomos [85]. 0 material, do qual é constituída a lâmina densa, possui um grande grau de similaridade com a substância intercelular cimentante, encontrada entre as células epiteliais [73]. Desta maneira, o tipo de adesão que acontece entre as células basais e a lâmina densa parece ser a mesma entre as células epiteliais [87].

A lâmina basal, além dos papéis estruturais e filtrantes já conhecidos, ainda é capaz de determinar a polaridade e influenciar o metabolismo celular, organizar as proteínas nas membranas plasmáticas das células adjacentes, promover a sobrevivência, proliferação ou diferenciação celular e ainda direcionar a migração celular. No epitélio do tipo escamoso estratificado esta corre paralelamente ao tecido conjuntivo, por meio das fibras de ancoragem especializadas, compostas por moléculas de colágeno do tipo VII. A sua composição precisa pode variar de tecido para tecido, ou ainda de região para região na lâmina do mesmo tecido. Algumas lâminas basais, com maior grau de maturação, possuem ainda fibras de colágeno do tipo IV [20].

A porção mais profunda da membrana basal é chamada de lâmina reticular, e consiste em fibras colágenas produzidas pelo próprio tecido conjuntivo. 
Mecanismos de adesão fazem parte das funções da membrana basal. Esses mecanismos envolvem os desmossomos com suas placas de adesão, as tonofibrilas do epitélio e as fibras de ancoragem de colágeno do tecido conjuntivo. As tonofibrilas laçam a placa de ancoragem (desmossomos), enquanto que as fibras de colágeno, da lâmina reticular laçam a lâmina densa, formando uma adesão flexível entre os dois tecidos. Essa interface consiste em uma estrutura tridimensionalmente interligada, aumentando a superfície de contato, proporcionando maior força e resistência, e ao mesmo tempo aumentando o potencial nutricional do epitélio avascular pelo tecido conjuntivo vascularizado [10, 24]. Substâncias que se movimentam do tecido conjuntivo para o epitélio e viceversa devem atravessar a membrana basal. Ao mesmo tempo em que possui a ação de barreira evitando que partículas maiores se movimentem livremente, [24, 85, 86] age atuando na suplementação da função de barreira das camadas superficiais do epitélio [86].

Como a maioria dos metabólitos que penetram ou deixam o epitélio devem atravessar a membrana basal, é evidente que a nível molecular a lâmina basal pode exercer um efeito filtrante [82], ou seja, somente partículas com diâmetros compatíveis (aproximadamente 5-6 nm) são capazes de atravessá-la. Essas conseguem passar livremente entre os espaços intercelulares da epiderme e do epitélio bucal, enquanto que moléculas maiores (aproximadamente 5-12,5 $\mathrm{nm}$ ) estão restritas a essa passagem. Assim, sugere-se que um mecanismo semelhante opere na direção oposta. Isso é observado, quando se aplica albumina marcada na superfície do epitélio bucal de animais testados e complexos imunológicos formados no mesmo são encontrados acima da membrana basal. De acordo com essa observação a membrana basal suplementa a função de barreira das camadas superficiais do epitélio [86].

A produção da membrana basal é interpretada como a manifestação estrutural de reconhecimento entre as células epiteliais e o tecido conjuntivo. Muito provavelmente essa identificação é mediada pela correspondência de propriedades específicas da superfície celular e do tecido conjuntivo [54].

A seguir na FIG. 5 podemos observar um esquema do complexo basal. 


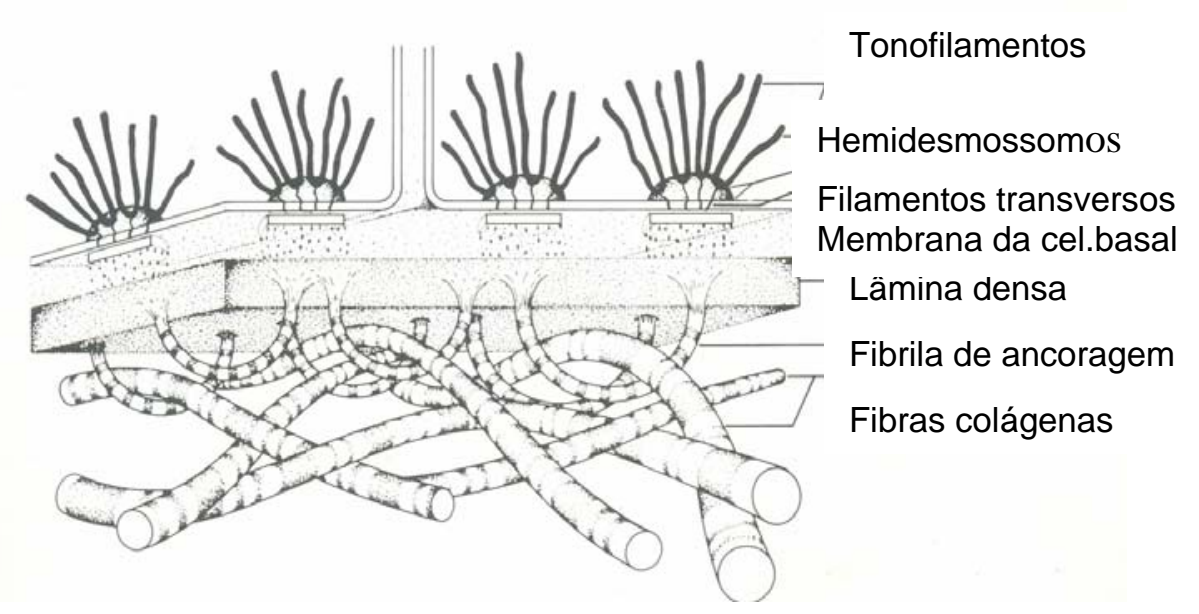

FIGURA 5 - Esquema representativo do complexo basal [24], modificada pela autora.

\subsection{Ciclo celular}

O epitélio bucal, assim como outros epitélios, é composto por uma constante renovação da população celular, na qual, sob condições normais, o número de células produzidas pela divisão celular na região da camada basal é suficiente para repor aquelas células perdidas pelo processo de descamação, o qual ocorre na região da superfície do epitélio. Assim sendo, as células progenitoras possuem duas funções: umas delas é manter o potencial proliferativo do epitélio e a outra é produzir células, as quais seguem o caminho da maturação e mantém, desta forma, a função do tecido [87, 88].

A direção a ser seguida por essas células (proliferação ou diferenciação) é modulada pela presença de fatores como: cálcio extracelular, forbol esteres, ácido retinóico e vitamina D3. As células da camada basal estão aderidas por um mecanismo, denominado adesão focal, contendo integrinas. A diferenciação dessas células envolve migração, com perda de expressão dessas integrinas, e aumento da adesão mediada pelas caderinas, via junção intercelular ou desmossomos. Ainda faz parte de todo esse processo a modificação na composição das proteínas intracelulares, as citoqueratinas e o desenvolvimento de novas proteínas incluindo as filagrinas, loricrinas e involucrinas [88].

Existe certa dificuldade em calcular e justificar o tempo exato de todo o processo de renovação celular no epitélio estratificado, apesar desta dificuldade chegou-se ao consenso de que esse tempo chega a ser menor no epitélio bucal quando comparado à epiderme, porém quando comparado ao epitélio intestinal, o 
tempo de renovação celular se torna maior $[86,87]$. O tempo estimado para a epiderme fica em torno de 12 a 75 dias, com uma média de aproximadamente 25 dias. Esse tempo, desta vez calculado para o epitélio bucal varia de 2 a 40 dias [86], atingindo uma média de 4 a 14 dias [86]. Nas diferentes regiões bucais ainda existem modificações neste tempo de renovação, a saber: no epitélio não queratinizado, a renovação celular acontece mais rapidamente, enquanto que no epitélio ortoqueratinizado ou paraqueratinizado (da gengiva, palato duro), esta renovação torna-se mais lenta [86, 87].

O controle da divisão celular parece estar determinado pela produção local de hormônios teciduais, denominados: chalonas. Esses hormônios parecem ser produzidos pelas células pós-mitóticas, e possuí a dupla propriedade de estimular a diferenciação celular e a inibição da mitose. Portanto o índice de divisão celular é aumentado em regiões onde há baixa concentração de chalonas. Um outro componente sistêmico, tal como a adrenalina, parece estar envolvido de alguma forma na ação das chalonas [86, 87]. Ainda outros fatores, tais como: ritmo diurno, idade, inflamação e stress, parecem estar envolvidos na influência da atividade mitótica. Diante de uma inflamação, uma pequena quantidade de infiltrado inflamatório pode estimular a atividade mitótica, enquanto que uma quantidade maior deste infiltrado pode reprimir a mesma atividade $[86,88]$.

Assumindo que as células da camada basal possuem tamanhos constantes, uma forma de avaliar a atividade proliferativa dessas células seria pela extensão, expressa pela membrana basal. Mesmo considerando essa forma de avaliação, deve-se levar em conta que a camada basal possui configuração variável para cada região da mucosa bucal e da pele. Provavelmente o método mais consistente de avaliar a atividade proliferativa, seria por meio da área da superfície a ser avaliada [24].

\subsection{Influência da idade no desenvolvimento da mucosa bucal.}

Todos os tecidos, de maneira geral, sofrem mudanças graduais cumulativas com a idade, associadas com o retardamento das atividades celulares [24]. Dentre os tecidos epiteliais, a pele é o tecido, em relação ao qual poderiam ser documentadas com detalhes as modificações celulares que ocorrem com a idade, pelos sinais aparentes, tais como: diminuição da espessura, aparecimento de rugas (pela alteração das fibras colágenas), coloração dos 
cabelos alterada, diminuição ou perda dos mesmos. Poderíamos relatar que tanto em função como em estrutura, uma grande parte destas modificações está relacionada com a exposição da mesma às radiações solares. Porém, quando voltamos nossa atenção para o epitélio bucal, notamos que pela própria localização, esse tecido se encontra protegido das agressões deste tipo de meio ambiente [86, 88]. Alguns estudos demonstraram uma atividade mitótica reduzida na mucosa bucal, com o avanço da idade [24]. Porém, algumas controvérsias a esse respeito ainda persistem, tornando desta maneira algumas afirmações não conclusivas [24]. Quando observamos a mucosa bucal de um idoso, notamos uma diminuição de sua espessura, frouxidão e ressecamento (xerostomia), mais acentuados e sintomas agora presentes, tais como: sensação de queimação, coceira, aspereza, falta de sensibilidade a certos paladares, especialmente em mulheres em fase pós-menopausa. Torna-se difícil determinar se a extensão dessas e de outras alterações mais específicas são inevitavelmente conseqüências da senescência programada pelos próprios tecidos, ou se são secundariamente devido a alterações locais, tais como: corrosão e desgaste, ou são secundárias a fatores sistêmicos do tipo: mudanças hormonais, nutricionais ou cardiovasculares. Richman e Abarbanel em 1943 [apud 86], demonstram que o aparecimento de placas brancas no epitélio bucal de mulheres em fase pósmenopausa seria devido à diminuição da espessura da camada de células espinhosas e conseqüente aumento da camada de queratina. Porém outros estudos realizados por Shklar, em 1966 [apud 86], demonstraram que o aumento desta camada ocorre somente no epitélio do palato duro, contrastando com resultados posteriores de estudos realizados em 1971, por Löe e Karring [apud 86], de que a população das células do epitélio gengival se mantém constante ao longo da vida [86].

\subsection{Aspectos de cultivo celular}

\subsubsection{Métodos de obtenção celular}

Vários métodos de extração de células para a realização de culturas primárias foram desenvolvidos até agora. Dentre os métodos mais freqüentemente encontrados na literatura para o cultivo de células epiteliais podemos citar o método enzimático, onde se utiliza uma enzima de desagregação e um outro método físico, denominado método do explante, envolvendo dissecção 
do fragmento com ou sem qualquer forma de maceração e subseqüente migração das células para fora do tecido. Ambos métodos devem permitir que as células, agora desagregadas do tecido, sejam capazes de aderir à superfície de cultivo e se multiplicar [37].

\subsubsection{Método Enzimático}

A adesão célula a célula nos tecidos é mediada por uma variedade de interações de glicopeptídeos homotípicos, as chamadas moléculas de adesão celular, algumas delas são cálcio dependente (caderinas) e como já descrito anteriormente, estas são sensíveis à ação de agentes enzimáticos. Este método, também denominado método de desagregação enzimática se dá pela ação de alguns agentes como a tripsina e o EDTA. Em geral quando se aumenta a pureza do agente obtém-se maior controle e menor toxicidade para as células e aumento da especificidade, porém isso pode acarretar menor atividade de desagregação. A tripsina é a enzima mais corriqueiramente utilizada em desagregação tecidual [37], sendo utilizada para dissociar vários tipos celulares. Qualquer atividade residual após sua utilização, deve ser neutralizada imediatamente por alguma sustância tampão que contenha cálcio em sua formulação. O próprio meio de cultura, contendo soro animal, costuma exercer esta função, sendo utilizado com certa freqüência, ou no caso da utilização de meio de cultura isento de soro animal, utiliza-se, por exemplo, um inibidor de tripsina à base de grãos de soja. Como método opcional, quando se expõe o tecido a ser dissociado à ação da tripsina à temperatura de $37^{\circ} \mathrm{C}$, colhe-se as células dissociadas a cada meia hora, e a tripsina deve ser removida pela centrifugação da solução já neutralizada [11, 37].

A enzima tripsina foi primeiramente testada por Medawar em 1941, na tentativa de dissociar a derme da epiderme, juntamente com propósitos e objetivos de atingir condições viáveis para a obtenção de epitélios transplantáveis e pesquisas na área biológica $[65,66]$.

\subsubsection{Método do Explante}

Este método foi primeiramente desenvolvido e utilizado, em 1907 por Harrison e posteriormente por Carrel em 1910, quando a técnica de cultivo celular teve início [22]. O objetivo deste método é promover a liberação e a migração das 
células do tecido na direção centrífuga, a partir do fragmento posicionado na superfície de cultivo. Segundo Freshney [37], esse método é bem utilizado quando se possui pouca quantidade de tecido para a realização da cultura primária, como no caso de fragmentos de pele, onde se corre o risco de perda de células durante a desagregação mecânica ou enzimática. Sua desvantagem está na adesividade do fragmento sobre a superfície de cultivo e na seleção das células migratórias provenientes do tecido.

Esse método permite reproduzir e visualizar in vitro o mecanismo de reepitelização, quando as células do tecido fragmentado migram e se multiplicam para fora do tecido $[49,62,64,101]$.

\subsection{Camada de Sustentação ou Feeder-Layer}

Em 1975, foi possível aprimorar ainda mais o sistema de cultivo de queratinócitos, quando pela primeira vez utilizou-se a camada de sustentação, denominada feeder-layer, para a propagação destas células, assim sendo possível a confecção de epitélios conseqüentemente transplantáveis [78]. A partir da introdução desse co-cultivo, foi possível a propagação dos queratinócitos em culturas posteriores e em quantidades anteriormente impossíveis de serem obtidas [35, 78], além da quantidade de células a serem cultivadas ser bem menor, quando se compara com a quantidade de células necessárias para dar início ao cultivo de queratinócitos em alta densidade [11]. Ao mesmo tempo esta camada de sustentação parece suprimir o crescimento dos fibroblastos [35, 78]. Isto parece ser possível devido à habilidade que o epitélio possui de se prender aos fibroblastos, enquanto os fibroblastos mostram-se incapazes de fazê-lo [35]. Ainda segundo Formanek 1996, a utilização da camada de sustentação se torna necessário para o cultivo dos queratinócitos, pois esta contribui positivamente para a adesão e proliferação dos mesmos [34]. Esta camada, descrita por Rheinwald e Green, é constituída por fibroblastos murinos modificados (3T3 Swiss albino), entretanto outros fibroblastos também podem ser utilizados, como exemplo: fibroblastos humanos. Estes fibroblastos são mitoticamente inativados por $\gamma$-irradiação ou mitomicina C. Essa camada de sustentação além de fornecer suporte físico permitindo o desenvolvimento dos queratinócitos em formato de colônias, é capaz de sintetizar substâncias essenciais para o desenvolvimento das células epiteliais [8, 11, 34, 38, 53, 63, 70, 78, 103]. 


\subsection{Eficiência de Formação de Colônias (EFC)}

Sob condições de cultivo, tais como as descritas no presente trabalho, os queratinócitos bucais humanos são capazes de formar colônias. Desta maneira é possível destacar essas células, presentes nas colônias, da placa de cultivo e realizar sub-culturas. Ao longo dessas passagens essas colônias se tornam uma mistura de células proliferativas e células em estágio de diferenciação terminal, como em seu meio natural [5]. Uma das características de grande significado é o tamanho dessas colônias. Essas colônias podem ser classificadas como colônias em desenvolvimento e colônias abortivas. As colônias em desenvolvimento são formadas, em sua maioria, por queratinócitos com grande potencial proliferativo, denominados queratinócitos basais. Quando essas células atingem um estágio de diferenciação, estas perdem a capacidade proliferativa, gerando agora colônias do tipo abortivas. O teste denominado "Eficiência de Formação de Colônias" nos fornece um parâmetro do estágio de desenvolvimento da cultura que esta sendo realizada paralelamente [5]. Além de nos mostrar visualmente o potencial de desenvolvimento da cultura, auxilia na determinação do número de duplicações que estas células in vitro são capazes de gerar [63]. Esse teste nos mostra a diferença da clonogenicidade das células semeadas.

\subsection{Determinação do tempo de vida celular em cultura (life-span)}

Esse teste, conhecido pelo termo inglês life-span, é utilizado para a determinação do tempo de vida útil que células, sob condições específicas de cultivo, são capazes de se manter.

Este é realizado semeando as células em garrafas próprias para cultivo celular. No momento em que as mesmas atingem a sub-confluência, são tripsinizadas, contadas e ressemeadas, na mesma densidade, em outra garrafa de cultura.

Para determinar o número de duplicações, utilizam-se os resultados obtidos por meio do teste de Eficiência de Formação de Colônias. Esses resultados são posteriores ao andamento da cultura, pois a eficiência de formação de colônias requer maior tempo.

Este procedimento (cultivo das células), é repetido até a impossibilidade destas células se manterem em cultura [63, 77, 79, 80]. 
Em 1987, Barrandon e Green descreveram um método de análise para revelar esse potencial proliferativo. Estes autores demonstraram por meio de clonagens, três tipos de clones de queratinócitos, a saber: holoclones, paraclones e meroclones.

Os holoclones formam rapidamente colônias de tamanhos superiores aos demais tipos, mostrando desta maneira, uma grande capacidade clonogênica e representam menos de $5 \%$ do total das células.

Os paraclones são representados por colônias de crescimento limitado, assim formam colônias de tamanho bastante inferior e disformes, quando comparadas ao tamanho das colônias formadas pelos holoclones, pois essas células atingem no máximo 15 duplicações.

Os meroclones formam dois tipos de colônias, aquelas colônias compostas por células que ainda possuem um determinado potencial clonogênico e colônias com células que estão em estágio de diferenciação terminal, mas que ainda são capazes de se duplicar de maneira mais lenta e limitada. A conversão de holoclone para meroclone e posteriormente paraclone é um processo unidirecional e irreversível, resultado de redução progressiva do potencial de duplicação desses queratinócitos [6]. Assim, por meio da life-span, podemos presumir a possibilidade da presença de uma maior ou menor quantidade de holoclones, meroclones e paraclones nas culturas analisadas.

\subsection{Hormônios adicionados ao meio de cultura para queratinócitos}

Hidrocortisona é essencial para manter o índice de crescimento e a diferenciação quando os queratinócitos são cultivados, ao mesmo tempo em que previne a deterioração da camada de sustentação (feeder - layer.) [69]. A adição de hidrocortisona em culturas subseqüentes restaura a aparência da estratificação epitelial regular, aumenta a expansão lateral [18] além de manter a morfologia das colônias [78]. A sua adição ao cultivo pode estimular ou inibir a proliferação celular, dependendo do tipo e da densidade celular [36].

Toxina do Cólera aumenta os níveis de AMP cíclico. O AMP cíclico é um dos mediadores intracelulares mais requisitados, diretamente relacionado ao ciclo celular. Mudanças em suas concentrações são estimuladas por diversos caminhos diferentes na maioria das células animais [20]. Assim, a toxina do 
cólera, por meio do AMP cíclico, age evitando a tendência dos queratinócitos de aumentar de tamanho, retardando desta maneira a diferenciação terminal dos mesmos $[40,69,74]$. Na concentração utilizada $(0,1 \mathrm{nM})$, não é tóxica, mesmo se essa concentração for aumentada (10 nM), sendo potencialmente efetivada em promover a multiplicação celular, nas concentrações de 0,01 nM ou 0,1 nM. A toxina do cólera aumenta a eficiência de formação de colônia, fato claramente observado em culturas de queratinócitos de doadores com idade avançada. Por ativar a adenil ciclase, a multiplicação dos queratinócitos ainda continua aumentada por algum período após sua retirada do meio de cultura [40].

EGF (fator de crescimento epidérmico), parece auxiliar evitando a tendência das células de se apinharem no centro das colônias [69, 79], estimulando a duplicação e a migração desses queratinócitos para fora desse centro, conseqüentemente aumentando a longevidade e a quantidade de células contidas nessas colônias [18, 79]. Parece antagonizar a diferenciação terminal e aumentar a capacidade de divisão da população clonogênica, por um mecanismo distinto daquele exercido pela adição da toxina do cólera. Assim, o efeito desses dois agentes em conjunto, melhora a capacidade de um único agente somente [69].

Juntos: hidrocortisona, toxina do cólera e EGF aumentam a fração clonogênica, o índice de crescimento populacional e a vida útil em cultura (lifespan), portanto um grande número de queratinócitos humanos cultivados pode ser obtido rapidamente, mesmo quando o tamanho do fragmento inicial é reduzido [69].

$\underline{\text { Insulina e triiodotironina }}$ (T3) permitem a redução da quantidade de soro fetal bovino incorporado ao meio de cultura de $20 \%$ para $10 \%$, ao mesmo tempo em que quando a qualidade do soro, de determinado lote, não seja a ideal, é capaz de aumentar o índice de crescimento da população de queratinócitos [69]. O T3 parece fornecer suporte para vários tipos de células [36].

O papel da insulina ainda não foi claramente definido. Segundo Freshney [36] este parece ser o hormônio essencial para a duplicação de quase todas as células quando cultivadas. Devido sua vida curta e sua sensibilidade à inativação pela cisteína, geralmente é adicionada em concentrações elevadas e imediatamente antes de sua utilização. Controvérsias ainda persistem, entre os 
grupos que a investigaram [44, 94, 100]. Fica porém esclarecido que, em pequenas quantidades, permite a entrada da glicose dentro dos queratinócitos, e em quantidades excessivas podem causar precipitação da concentração de glicose no meio de cultura. Alguns grupos ainda concluíram que a presença de glicose no meio pode estimular um crescimento em torno de 30\% [18].

Adenina, adicionado ao meio de cultura, inibe a proliferação de fibroblastos e conseqüentemente a presença indesejada dessas células na cultura de queratinócios [18, 83].

\subsection{Cultura de queratinócitos em alta densidade}

O cultivo de queratinócitos isento da utilização da camada de sustentação, torna-se possível quando realizado com as células semeadas em alta densidade. Isso se dá, cultivando inicialmente quantidade de células dez vezes superior $\left(6 \times 10^{4} / \mathrm{cm}^{2}\right)$ à quantidade utilizada no cultivo sobre a camada de sustentação feeder-layer [11]. Como vantagem, esta técnica exclui a necessidade do cultivo e posterior tratamento dos fibroblastos.

\subsection{Cultura de queratinócitos em meio de cultura isento de soro animal (K- SFM)}

Esta técnica é uma variável de condições de cultivo, a qual permite cultivar células epiteliais sem a suplementação de soro animal ao meio de cultura. Para isso, como descrito na técnica anterior, exclui-se a camada de sustentação, procedendo ao cultivo denominado de "alta densidade". O meio utilizado, denominado K-SFM (keratinocyte serum free medium), deve ser suplementado com extrato pituitário e fator de crescimento (EGF) [80].

\subsection{Análise histológica}

Este tipo de análise nos permite visualizar, por transparência, estruturas e componentes impossíveis de serem visualizados em tecidos vivos. Esta análise é realizada com o tecido morto, quimicamente preservado e cortado, em cortes finos, denominados "cortes histológicos", os quais são posteriormente fixados em lâminas de vidro. Estes cortes podem ser corados com diversos corantes a fim de se aumentar o contraste das estruturas componentes do fragmento a ser analisado e facilitar a visualização e o reconhecimento ao microscópio ótico $[13,50]$. 


\section{MATERIAS E MÉTODOS}

\section{Materiais:}

Esse projeto obteve a aprovação do Comitê de Ética em Pesquisa do Instituto de Pesquisas Energéticas e Nucleares (IPEN/CNEN-SP) sob $0 \mathrm{n}^{\circ}$ 087/CEP-IPEN/SP (ANEXO A). Os experimentos foram realizados utilizando tecido epitelial, proveniente de mucosa bucal de doadores voluntários (TAB.1). Esses doadores são pacientes saudáveis, assim como não fazem uso de fumo, álcool ou quaisquer outros tipos de droga, que possam interferir em nossos resultados [8, 24, 27, 41, 44, 51, 61, 80]. Esses pacientes responderam as perguntas de um questionário informativo (vide APÊNDICE A), preencheram o termo de consentimento pós-informação, proposto pelo comitê de ética em pesquisa do IPEN/CNEN-SP (resolução $n^{\circ} 01$ de 13.06.98 - CNS) (vide ANEXO B) e os instrumentos de doação de tecidos bucais, propostos pela faculdade de Odontologia da Faculdade de São Paulo (FOUSP) (vide ANEXO C).

Esses epitélios foram retirados durante procedimentos cirúrgicos do tipo: correção de rebordo dentário, recebimento de pinos para a colocação de implantes dentários, remoção de terceiros molares inclusos, gengivoplastia e remoção de freio labial.

Os cirurgiões dentistas que executaram estes procedimentos também assinaram o instrumento de doação de tecido bucal (resolução n 196/96 - CNS), propostos pela FOUSP (vide ANEXO D).

A seguir na TAB. 1 é mostrada as características dos pacientes voluntários quanto ao sexo, idade, cor da pele e tipo de cirurgia.

TABELA 1 - Classificação dos pacientes voluntários

\begin{tabular}{|c|c|c|c|c|c|}
\hline $\begin{array}{l}\text { Pacientes } \\
\text { Volunt. }\end{array}$ & Sexo & $\begin{array}{l}\text { Idade } \\
\text { (anos) }\end{array}$ & Cor & Tipo de cirurgia & $\begin{array}{l}\text { Região bucal } \\
\text { correspond. }\end{array}$ \\
\hline V 01 & $\mathrm{~F}$ & 55 & $\mathrm{Br}$ & $\begin{array}{l}\text { Reabertura de } \\
\text { implante }\end{array}$ & 12 a 22 \\
\hline V 02 & $\mathrm{M}$ & 34 & $\mathrm{Br}$ & $\begin{array}{l}\text { Remoção raiz } \\
\text { residual }\end{array}$ & 36 \\
\hline V 03 & $\mathrm{~F}$ & 14 & $\mathrm{Br}$ & Ulectomia & 37 \\
\hline V 04 & $\mathrm{~F}$ & 15 & $\mathrm{Br}$ & Gengivoplastia & 13 a 23 \\
\hline V 05 & M & 11 & $\mathrm{Br}$ & Ulectomia & 37 \\
\hline V 06 & $F$ & 44 & $\mathrm{Br}$ & $\begin{array}{l}\text { Reabertura de } \\
\text { implante }\end{array}$ & 35 \\
\hline V 07 & $\mathrm{~F}$ & 43 & $\mathrm{Br}$ & $\begin{array}{l}\text { Reabertura de } \\
\text { implante }\end{array}$ & 35 \\
\hline
\end{tabular}




\begin{tabular}{|c|c|c|c|c|c|}
\hline $\begin{array}{l}\text { Pacientes } \\
\text { Volunt. }\end{array}$ & Sexo & $\begin{array}{l}\text { Idade } \\
\text { (anos) }\end{array}$ & Cor & Tipo de cirurgia & $\begin{array}{l}\text { Região bucal } \\
\text { correspond. }\end{array}$ \\
\hline V 08 & $\mathrm{M}$ & 41 & $\mathrm{Br}$ & $\begin{array}{c}\text { Reabertura de } \\
\text { implante }\end{array}$ & 35 \\
\hline V 09 & $\mathrm{M}$ & 15 & $\mathrm{Br}$ & $\begin{array}{l}\text { Remoção } 3^{\circ} \text { molar } \\
\text { incluso }\end{array}$ & 38 \\
\hline V 10 & $\mathrm{~F}$ & 25 & $\mathrm{Br}$ & $\begin{array}{c}\text { Remoção } 3^{\circ} \text { molar } \\
\text { incluso }\end{array}$ & 38 \\
\hline V 11 & $\mathrm{~F}$ & 68 & $\mathrm{Br}$ & Frenectomia & lábio superior \\
\hline$\vee 12$ & $M$ & 19 & $\mathrm{Br}$ & $\begin{array}{c}\text { Remoção } 3^{\circ} \text { molar } \\
\text { incluso }\end{array}$ & 38 \\
\hline V 13 & M & 21 & $\mathrm{Br}$ & $\begin{array}{l}\text { Remoção } 3^{\circ} \text { molar } \\
\text { incluso }\end{array}$ & 48 \\
\hline V 14 & $\mathrm{~F}$ & 19 & $\mathrm{Br}$ & Ulectomia & 38 \\
\hline V 15 & M & 21 & $\mathrm{Br}$ & $\begin{array}{c}\text { Remoção } 3^{\circ} \text { molar } \\
\text { incluso }\end{array}$ & 28 \\
\hline V 16 & $\mathrm{~F}$ & 35 & $\mathrm{Br}$ & $\begin{array}{c}\text { Remoção } 3^{\circ} \text { molar } \\
\text { incluso }\end{array}$ & 38 \\
\hline V 17 & $\mathrm{~F}$ & 17 & $\mathrm{Br}$ & $\begin{array}{c}\text { Remoção } 3^{\circ} \text { molar } \\
\text { incluso }\end{array}$ & 48 \\
\hline V 18 & $\mathrm{M}$ & 25 & $\mathrm{Br}$ & $\begin{array}{c}\text { Remoção } 3^{\circ} \\
\text { molares inclusos }\end{array}$ & 18 e 38 \\
\hline $\begin{array}{l}\vee 19 a \\
\vee 19 b\end{array}$ & $\mathrm{~F}$ & 31 & $\mathrm{Br}$ & $\begin{array}{l}\text { Gengivoplastia e } \\
\text { frenectomia }\end{array}$ & $\begin{array}{c}13 \text { a } 23 \text { e } \\
\text { lábio superior }\end{array}$ \\
\hline V 20 & $\mathrm{~F}$ & 13 & $\mathrm{Br}$ & $\begin{array}{l}\text { Remoção } 3^{\circ} \text { molar } \\
\text { incluso }\end{array}$ & 85 \\
\hline V 21 & $\mathrm{~F}$ & 33 & $\mathrm{Br}$ & $\begin{array}{c}\text { Remoção } 3^{\circ} \text { molar } \\
\text { incluso }\end{array}$ & 48 \\
\hline V 22 & $\mathrm{~F}$ & 23 & $\mathrm{Br}$ & $\begin{array}{c}\text { Remoção } 3^{\circ} \text { molar } \\
\text { incluso }\end{array}$ & 38 \\
\hline V 23 & $\mathrm{~F}$ & 20 & $\mathrm{Br}$ & $\begin{array}{l}\text { Remoção } 3^{\circ} \text { molar } \\
\text { incluso }\end{array}$ & 38 \\
\hline V 24 & $\mathrm{~F}$ & 22 & $\mathrm{Br}$ & $\begin{array}{l}\text { Remoção } 3^{\circ} \text { molar } \\
\text { incluso }\end{array}$ & 48 \\
\hline V 25 & $\mathrm{~F}$ & 16 & $\mathrm{Br}$ & $\begin{array}{c}\text { Remoção } 3^{\circ} \text { molar } \\
\text { incluso }\end{array}$ & 48 \\
\hline V 26 & $\mathrm{~F}$ & 15 & parda & $\begin{array}{c}\text { Remoção } 3^{\circ} \text { molar } \\
\text { incluso }\end{array}$ & 18 \\
\hline V 27 & $F$ & 18 & $\mathrm{Br}$ & $\begin{array}{l}\text { Remoção } 3^{\circ} \text { molar } \\
\text { incluso }\end{array}$ & 48 \\
\hline V 28 & $\mathrm{~F}$ & 26 & $\mathrm{Br}$ & $\begin{array}{l}\text { Remoção } 3^{\circ} \text { molar } \\
\text { incluso }\end{array}$ & 38 \\
\hline V 29 & $\mathrm{~F}$ & 24 & $\mathrm{Br}$ & $\begin{array}{c}\text { Remoção } 3^{\circ} \text { molar } \\
\text { incluso }\end{array}$ & 38 \\
\hline V 30 & $\mathrm{~F}$ & 26 & $\mathrm{Br}$ & Ulectomia & 38 \\
\hline V 31 & $\mathrm{~F}$ & 25 & $\mathrm{Br}$ & $\begin{array}{c}\text { Remoção } 3^{\circ} \\
\text { molares inclusos }\end{array}$ & 28,38 e 48 \\
\hline V 32 & $\mathrm{~F}$ & 23 & parda & $\begin{array}{l}\text { Remoção } 3^{\circ} \text { molar } \\
\text { incluso }\end{array}$ & 48 \\
\hline V 33 & M & 30 & $\mathrm{Br}$ & $\begin{array}{l}\text { Remoção } 3^{\circ} \text { molar } \\
\text { incluso }\end{array}$ & 38 \\
\hline V 34 & $F$ & 19 & $\mathrm{Br}$ & $\begin{array}{c}\text { Remoção } 3^{\circ} \text { molar } \\
\text { incluso }\end{array}$ & 48 \\
\hline
\end{tabular}

12 a 22 - Incisivos anteriores superiores, 13 a 23 - bateria anterior superior, 35 segundo pré-molar inferior esquerdo, 18 - terceiro molar superior direito, 28 - terceiro molar superior esquerdo, 36 - primeiro molar inferior esquerdo, 37 - segundo molar inferior esquerdo, 38 - terceiro molar inferior esquerdo, 48 - terceiro molar inferior direito, 85 - segundo molar direito decíduo. 


\section{Fluxograma de Trabalho 1}

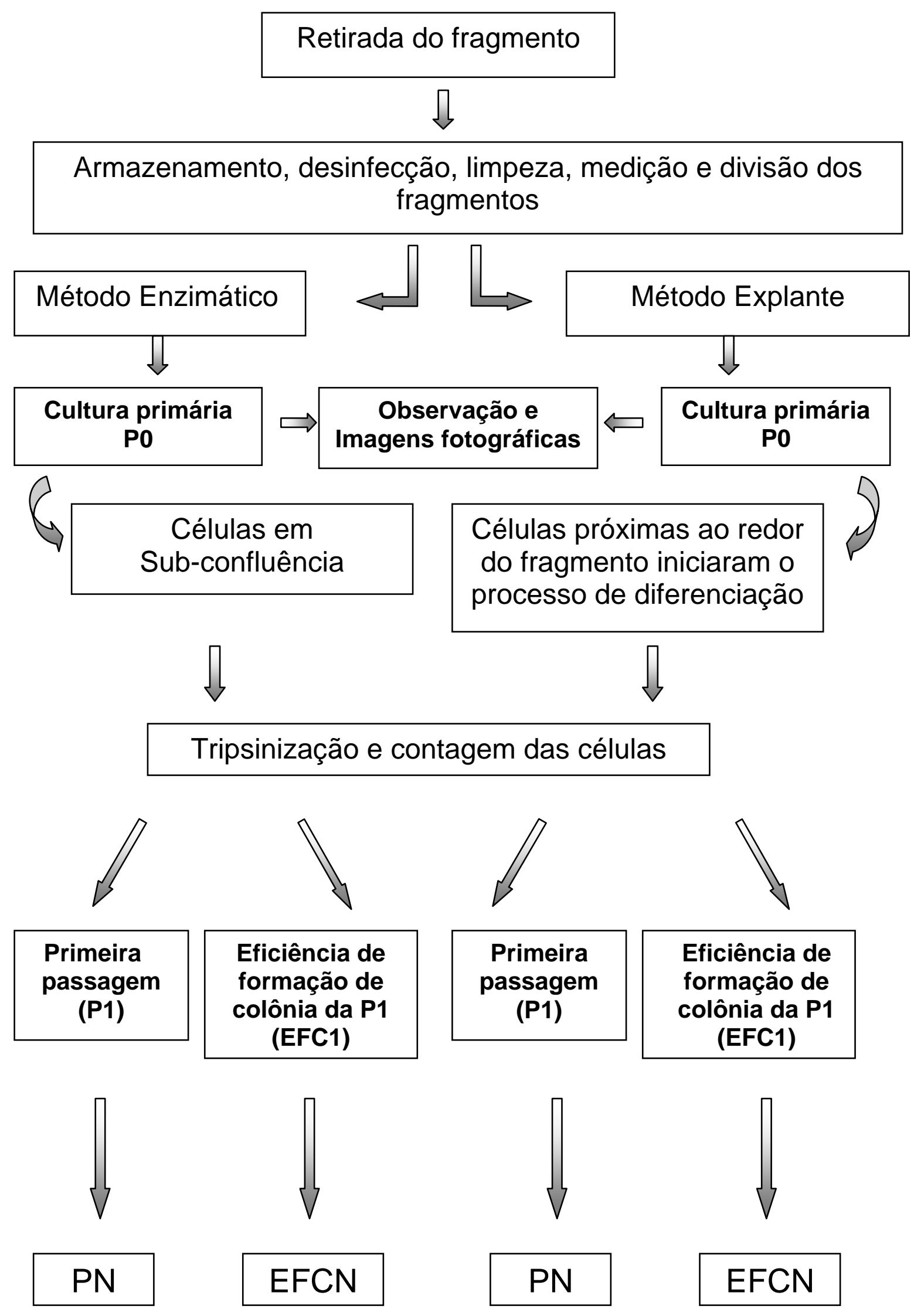




\section{Fluxograma de Trabalho 2} (Testes Comparativos)

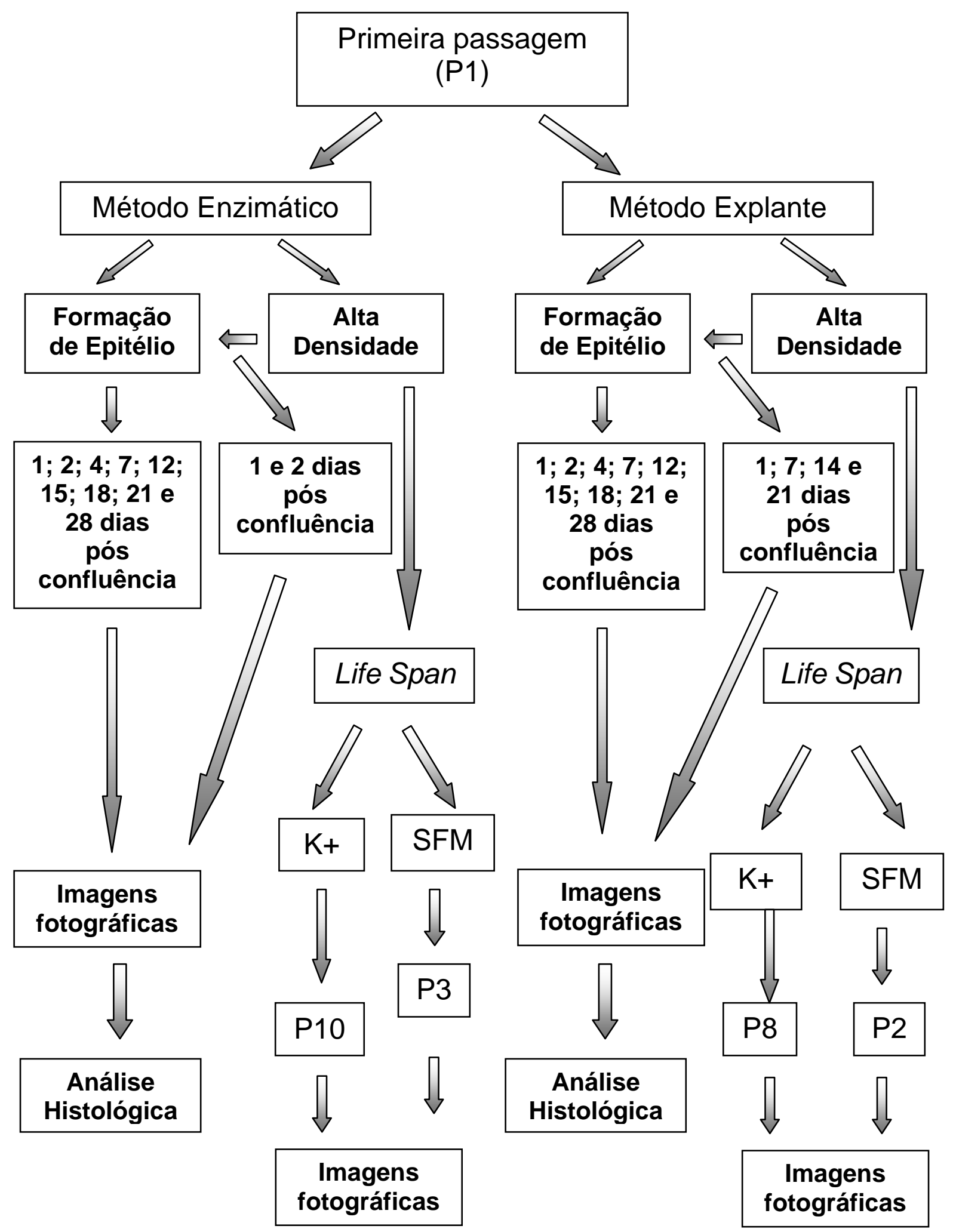




\section{Métodos:}

Nos fluxogramas de trabalho 1 (pg. 47) e 2 (pg. 48), estão apresentados a seqüência dos experimentos executados. Os detalhamentos dos métodos utilizados do fluxograma de trabalho 1 estão descritos nos itens 4.1 até 4.3.2 e nos itens 4.4 até 4.5. E os detalhamentos dos métodos utilizados do fluxograma de trabalho 2 estão descritos nos itens 4.3 .3 e 4.3 .4 e nos itens $4.6 \mathrm{e}$ 4.7.

\subsection{Preparo do material}

O material coletado foi armazenado em meio de cultura (DMEM), isento de soro fetal bovino, à temperatura de $4^{\circ} \mathrm{C}$, por no máximo 24 horas, acrescido de penicilina $(200 \mathrm{U} / \mathrm{mL})$, estreptomicina $(200 \mu \mathrm{g} / \mathrm{mL})$, gentamicina $(80 \mu \mathrm{g} / \mathrm{mL})$, anfotericina $B(50 \mu \mathrm{g} / \mathrm{mL})[30,31,32,47,51]$.

A partir deste passo, todo o procedimento foi realizado em cabine de fluxo laminar do tipo vertical. $O$ tecido coletado foi submetido primeiramente a uma lavagem em solução fisiológica durante alguns segundos, para a remoção de possíveis resíduos de sangue. Em seguida fez-se uma prévia desinfecção com solução alcoólica a $70 \%$, durante aproximadamente 15 segundos, para então proceder ao enxágüe, que foi repetido por duas vezes em solução fisiológica, e uma terceira vez, agora com a mesma solução fisiológica acrescida de: penicilina $(100 \mathrm{U} / \mathrm{mL})$, estreptomicina $(100 \mu \mathrm{g} / \mathrm{mL})$, gentamicina $(40 \mu \mathrm{g} / \mathrm{mL})$, anfotericina $B$ $(2.5 \mu \mathrm{g} / \mathrm{mL})[30,31,32,46,51]$.

Após sua desinfecção foi feita a limpeza sobre uma placa de vidro, utilizando pinça clínica, tesoura cirúrgica ou lâmina de bisturi. Em seguida realizou-se a medição, feita com régua metálica, para proceder à divisão deste em duas partes iguais, onde foi utilizada lâmina de bisturi.

A seguir nas FIG. 6 e FIG. 7, são mostradas as imagens fotográficas de tais procedimentos. 

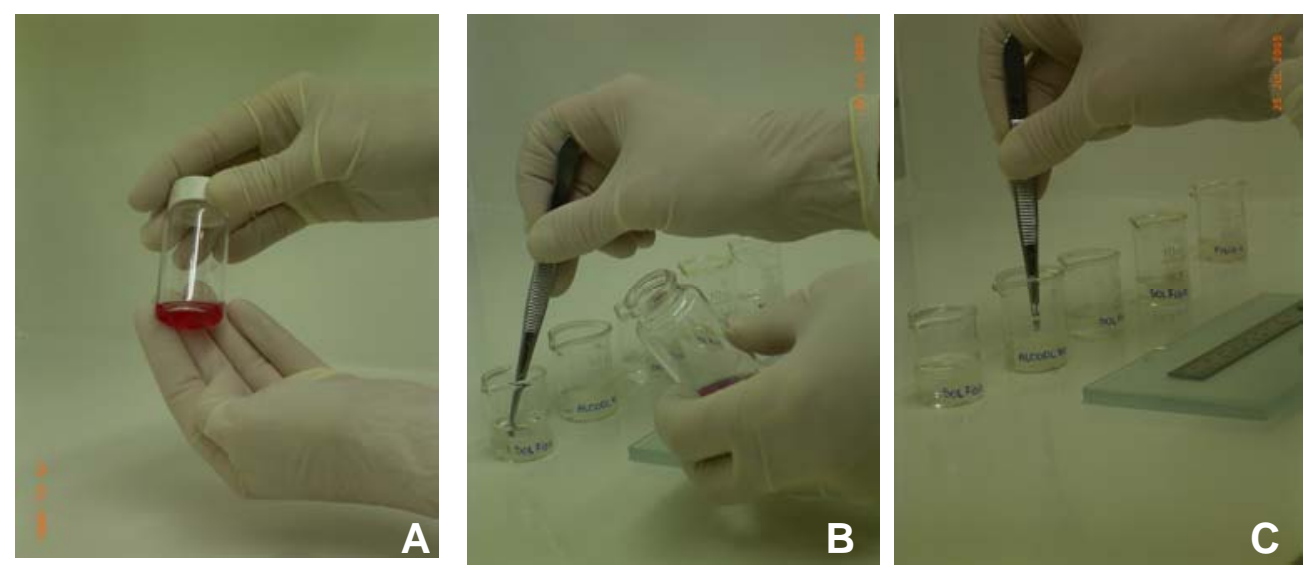

FIGURA 6 - Imagem fotográfica do preparo do fragmento bucal coletado para realização dos métodos de obtenção de células a serem comparados. (A) Coleta e armazenamento do fragmento. (B e C) Desinfecção do fragmento bucal.
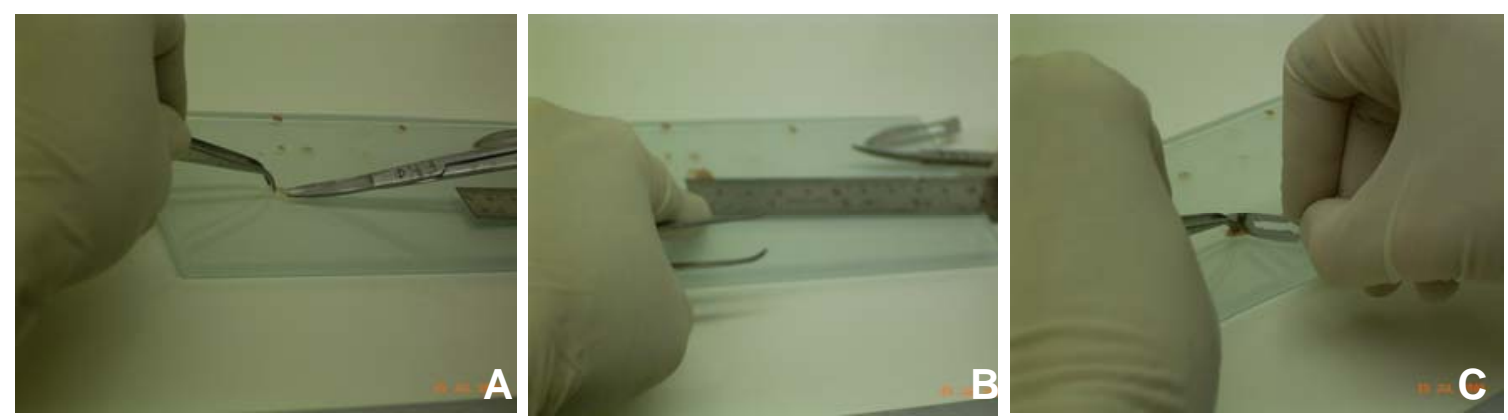

FIGURA 7 - Imagem fotográfica do preparo do fragmento bucal coletado para a realização dos métodos de obtenção de células a serem comparados. (A) Limpeza do fragmento com tesoura cirúrgica. (B) Medição do fragmento com régua metálica. (C) Divisão do fragmento em duas partes iguais feitas com lâmina de bisturi.

\subsection{Métodos empregados}

Para o presente trabalho, foram empregados dois métodos para a obtenção de células, método enzimático e método do explante.

\subsubsection{Método enzimático}

O fragmento inicial foi cortado em fragmentos menores $(0.5 \mathrm{~mm} \times 0.5$ $\mathrm{mm}$ ), com o auxílio de uma tesoura cirúrgica, e estes foram imersos em solução de tripsina 0,05\%/EDTA 0,02\% (Gibco: 25.300-054), sob agitação branda a $37^{\circ} \mathrm{C}$. A intervalos de 30 minutos, foi colhido o sobrenadante com as células; a ação da tripsina foi neutralizada com meio de cultura contendo $10 \%$ de soro fetal bovino, penicilina (100 U/mL), (estreptomicina) $(100 \mu \mathrm{g} / \mathrm{mL})$, anfotericina $B(2.5 \mu \mathrm{g} / \mathrm{mL})$ (Gibco-15.240-062). A mistura foi centrifugada a 1500 rpm durante 5 minutos. Em seguida o sobrenadante foi aspirado e as células ressuspendidas em meio de 
cultura próprio para cultivo de queratinócitos (K-), constituído de: DMEM (Gibco: 11.965-092) e meio de Ham F12 (Gibco: 11065-047) (na proporção de 2:1), contendo $10 \%$ de soro fetal bovino (Hyclone: Fetal Clone III SH 30.109-03), penicilina (100 U/mL), estreptomicina (100 $\mu \mathrm{g} / \mathrm{mL})$, gentamicina $(50 \mu \mathrm{g} / \mathrm{mL})$, anfotericina B (2.5 $\mathrm{g} / \mathrm{mL})$, glutamina (4 mM) (Gibco BRL: 21.051-040), adenina (0,18 mM) (Sigma: A 9795), insulina (5 $\mathrm{g} / \mathrm{mL})$ (Sigma: I 1882), hidrocortisona $(0,4$ $\mu \mathrm{g} / \mathrm{mL}$ ) (Sigma: H 0396), toxina do cólera (0,1 nM) (Sigma: C 3012), triiodotironina (20 pM) (Sigma: T 5516) [8, 11, 28, 41, 44, 45, 63]. Esse procedimento foi repetido até a impossibilidade da visualização do precipitado de células (também denominado de "botão celular"), quando então foi realizada a contagem de células obtidas durante todo o procedimento de extração. Essa contagem foi feita em uma câmara hemocitométrica em microscópio de luz invertida.

As células $\left(6 \times 10^{3}\right.$ células $\left./ \mathrm{cm}^{2}\right)$ foram semeadas sobre uma camada de sustentação (feeder-layer) de 3T3- Swiss albino, linhagem de fibroblastos murinos (ATCCl $\mathrm{N}^{\circ}$ de catálogo CCL-92) (vide 4.4.1.2.). O conjunto: queratinócitos/camada de sustentação foi nutrido por meio de cultura do tipo K-, com troca de meio a cada dois dias. A partir da primeira troca de meio, foi adicionado EGF (hormônio de crescimento epidérmico) (R\&D Systems 236-EG), na concentração de $10 \mathrm{ng} / \mathrm{mL}(\mathrm{K}+)$. Estas células foram mantidas em incubadora úmida a $37^{\circ} \mathrm{C}$ com $5 \%$ de $\mathrm{CO}_{2}[11,41,44,45,63]$. Assim que estas células atingiram a sub-confluência (P0), foram retiradas da garrafa por tripsinização, contadas em câmara hemocitométrica e realizada a propagação das mesmas em cultura. procedimentos.

A seguir nas FIG. 8 e FIG. 9 , são mostradas ilustrações de tais
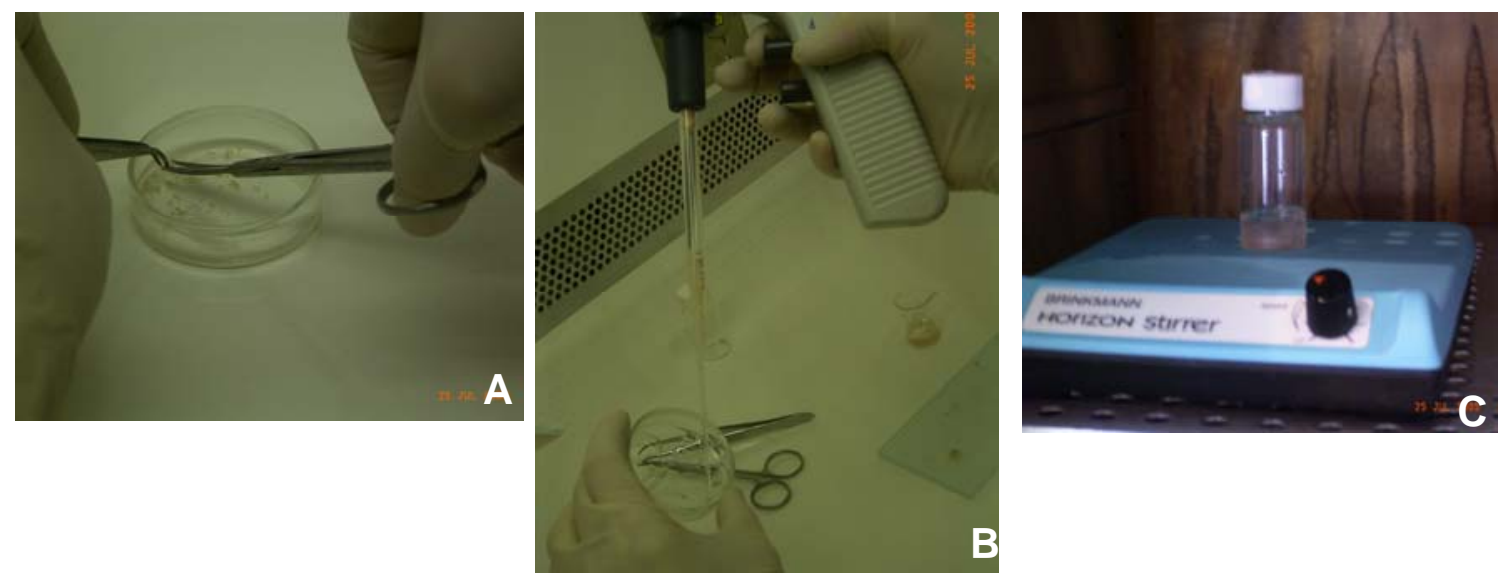

FIGURA 8 - Preparação do fragmento para a realização do método enzimático. (A) Fragmentação do epitélio em placa de vidro contendo tripsina/EDTA, com tesoura cirúrgica. (B) Colocação do conteúdo (epitélio mais tripsina/EDTA), com auxílio de uma pipeta de vidro, num frasco de vidro, contendo barra magnética. (C) Frasco de vidro com o 

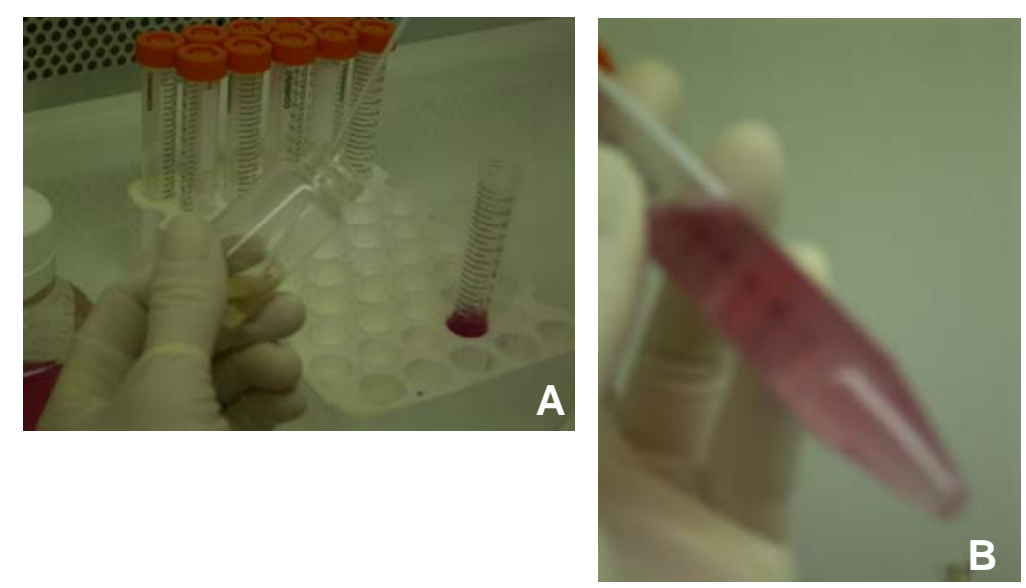

FIGURA 9 - Preparação do fragmento para a realização do método enzimático. (A) Neutralização do conteúdo (fragmentos, tripsina/EDTA) com meio de cultura contendo soro fetal bovino a 10\%. (B) Visualização do botão celular após centrifugação.

\subsubsection{Método do explante.}

Após a lavagem e desinfecção do material coletado, o tecido gengival foi cortado em fragmentos, agora de aproximadamente $1 \mathrm{~mm}^{2}$. Os fragmentos foram posicionados na placa de cultura, tomando-se o cuidado de deixá-los com a superfície epitelial voltada para a placa de cultura [57]. Esses pequenos fragmentos foram previamente umedecidos com solução fisiológica acrescida de antibiótico, como anteriormente mencionado (vide 4.1.) antes de serem posicionados na placa de cultivo. Após devidamente posicionados na posição desejada, foram gotejadas, entre os fragmentos, meio de cultura (D10) e estas placas com os fragmentos posicionados, foram incubadas a $37^{\circ} \mathrm{C}$, em incubadora úmida com $5 \%$ de $\mathrm{CO}_{2}$ por aproximadamente 24 horas, para possibilitar a adesão desses fragmentos e ao mesmo tempo mantê-los úmidos (FIG. 10) [36, 57]. Passadas 24 horas, esses fragmentos foram cobertos com meio de cultura do tipo D10, composto por: DMEM (meio de Eagle modificado por Dulbecco), contendo $10 \%$ de soro fetal bovino, glutamina $(4 \mathrm{mM})$, penicilina $(100 \mathrm{U} / \mathrm{mL})$, estreptomicina (100 $\mu \mathrm{g} / \mathrm{mL})$, anfotericina B $(2.5 \mu \mathrm{g} / \mathrm{mL})$ e gentamicina $(50 \mu \mathrm{g} / \mathrm{mL})$ [53]. Essas culturas foram diariamente observadas ao microscópio de luz invertida. Assim que essas células epiteliais, após iniciarem a sua multiplicação ao redor dos fragmentos do tecido gengival, atingiram um diâmetro de 2-5 mm, o meio de cultura foi trocado por $\mathrm{K}+$. Quando as células próximas dos fragmentos iniciaram o processo de diferenciação (P0), aumentando de diâmetro, as mesmas foram 
retiradas da garrafa por tripsinização, contadas em câmara hemocitométrica e realizada a propagação das mesmas em cultura [53].

A seguir na FIG. 10 são mostradas ilustrações de tais procedimentos.
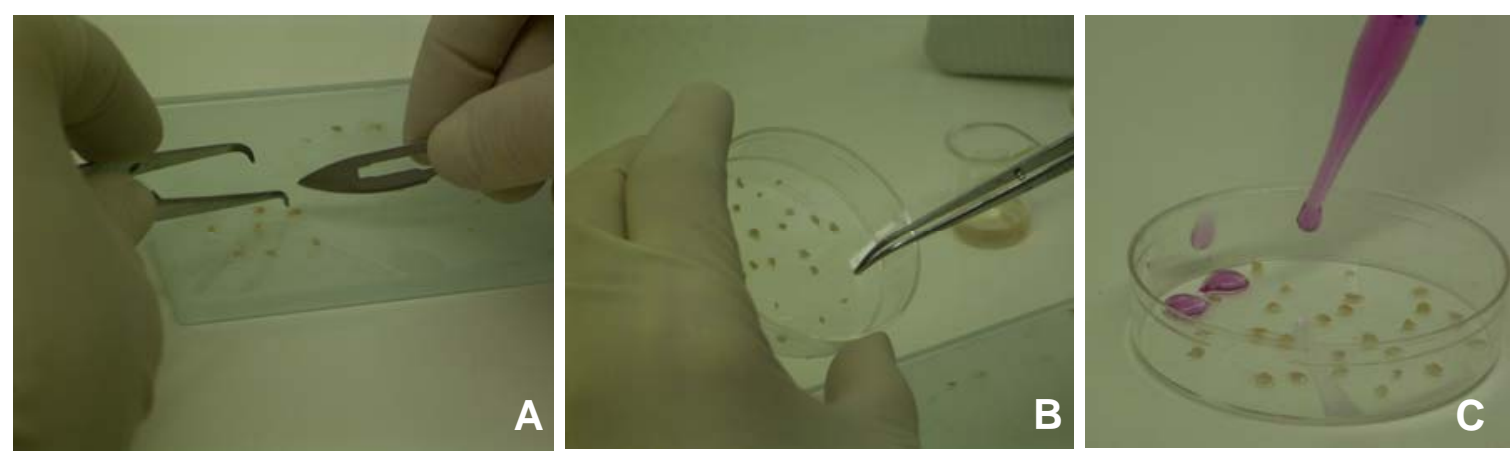

FIGURA 10 - Preparação do fragmento para a realização do método explante. (A) Fragmentação do epitélio sobre a placa de vidro com auxílio da uma lâmina de bisturi. (B) Posicionamento dos fragmentos sobre a placa de cultura celular, com auxílio de uma pinça clínica. (C) Pipetação do meio de cultura entre os fragmentos posicionados na placa de cultura.

\subsection{Propagação celular}

\subsubsection{Estabelecimento da camada de sustentação}

\subsubsection{Cultivo dos fibroblastos murinos para a confecção da camada de sustentação feeder layer}

Estes fibroblastos foram cultivados em meio de cultura D10, como anteriormente mencionado (soro bovino utilizado: Gibco, cat. 16030-074), desta vez sem o acréscimo de gentamicina. Essas células foram incubadas a $37^{\circ} \mathrm{C}$ em incubadora úmida com $5 \%$ de $\mathrm{CO}_{2}$, até atingirem a sub-confluência, ou seja, até preencherem 70\% a 80\% da área total da garrafa de cultura. Quando as células atingiram a sub-confluência, foram submetidas a tratamento enzimático com solução de tripsina 0,05\%/EDTA 0,02\%, por 5 minutos, sendo separadas em suspensão, e conforme a necessidade, mantidas em cultura para posterior utilização.

\subsubsection{Preparação da camada de sustentação}

Essas células, em suspensão, foram expostas à fonte de irradiação de ${ }^{60}$ Co, tipo Gamma Cell, com atenuador de 90\%, para irradiação a 60 Gy, e então semeadas em garrafas próprias para cultura celular, em concentração de $3 \times$ $10^{4} / \mathrm{cm}^{2}[11,53,63]$. 


\subsubsection{Propagação dos queratinócitos sobre camada de sustentação (feeder- layer)}

Em ambos métodos, depois que a cultura primária de queratinócitos foi estabelecida, foram realizadas as propagações dessas células em culturas subseqüentes (P1; P2; P3; P4;......Pn).

Essas passagens foram realizadas todas as vezes que a cultura atingiu a sub-confluência. Quando isso ocorreu, procedeu-se a tripsinização dessas células, feita primeiramente por 5 minutos com solução de EDTA 0,04\% e posteriormente por mais 10 a 15 minutos, com solução de tripsina 0,05\%/EDTA 0,02\%, neutralizando em seguida a função enzimática da tripsina com meio de cultura, contendo $10 \%$ de soro fetal bovino, penicilina $(100 \mathrm{U} / \mathrm{mL})$, estreptomicina $(100 \mu \mathrm{g} / \mathrm{mL})$, anfotericina $\mathrm{B}(2.5 \mu \mathrm{g} / \mathrm{mL})$ e centrifugando a $1500 \mathrm{rpm}$, durante 5 minutos. Em seguida todo o meio de cultura foi aspirado, deixando no fundo do tubo o precipitado celular. Essas células foram ressuspendidas em meio K-, descrito anteriormente, contadas em câmara hemocitométrica sob microscópio de luz invertida, e novamente semeadas $\left(6 \times 10^{3}\right.$ células $\left./ \mathrm{cm}^{2}\right)$ sobre nova camada de sustentação, Feeder-Layer, em garrafas próprias para cultura de células. O conjunto queratinócitos/camada de sustentação foi mantido em cultura, em atmosfera úmida à $37^{\circ} \mathrm{C}$ com $5 \%$ de $\mathrm{CO}_{2}$, com troca de meio a cada dois dias [11, 63].

\subsubsection{Cultivo dos queratinócitos em alta densidade}

Esse tipo de cultivo é realizado sem a presença e utilização da camada de sustentação. Para isso, foi necessário semear quantidade de células superior do que as quantidades necessárias para os cultivos feitos sobre camada de sustentação. O meio de cultura utilizado neste caso foi $\mathrm{K}+$, como já descrito anteriormente (vide 4.2.1). A propagação das células, em culturas subseqüentes, foi feita da mesma maneira, em alta densidade. No presente trabalho, este cultivo foi realizado com queratinócitos provenientes do mesmo voluntário, na passagem iniciais P2, provenientes de ambos os métodos de extração celular. Concomitantemente foi realizado a Eficiência de Formação de Colônias (vide 4.5) correspondente a cada passagem e calculado o número de gerações atingidas (vide 4.6) [11]. 


\subsubsection{Cultivo dos queratinócitos com meio de cultura isento de soro fetal bovino (K-SFM)}

Foi utilizado para a realização deste cultivo meio de cultura isento de soro fetal bovino, K-SFM (LGC Bio: BR 30.297.02). Além do acréscimo dos antibióticos, como no meio de cultura do tipo $\mathrm{K}+$, anteriormente descrito, este foi suplementado com extrato pituitário bovino $(25 \mu \mathrm{g} / \mathrm{mL})$ e EGF (10 ng/mL). Como no cultivo em alta densidade, descrito anteriormente, este cultivo foi realizado com queratinócitos provenientes do mesmo voluntário, na passagem $\mathrm{P} 2$, provenientes de ambos métodos de extração celular. Concomitante foi realizado a Eficiência de Formação de Colônias correspondente a cada passagem e calculado o número de gerações atingidas $[11,98,100]$.

\subsection{Eficiência de formação de colônias}

\subsubsection{Cultura das células}

A EFC é derivada de culturas obtidas a partir de 100 células, semeadas sobre a camada de sustentação, mencionada anteriormente (vide 4.3.1.2). Estas células foram mantidas, com troca de meio a cada dois dias, por catorze dias, formando colônias visíveis macroscopicamente. Cada colônia corresponde a uma célula semeada que aderiu à placa e que se multiplicou posteriormente. A EFC foi calculada pela porcentagem do número de colônias obtidas em relação ao número de células semeadas. Portanto, todas as vezes que executamos uma nova passagem, realizamos a Eficiência de Formação de Colônias correspondente, pois por meio desta é possível detectar a partir da quantidade de células semeadas, quantas delas foram capazes de se reproduzir [63, 78].

\subsubsection{Ensaio com corante não vital}

Para melhor visualização das colônias obtidas com o cultivo das células em baixa densidade, após catorze dias, estas foram incubadas por 5 minutos, com $1 \mathrm{ml}$ de Rodamina $\mathrm{B}\left(\mathrm{C}_{28} \mathrm{H}_{31} \mathrm{C}_{1} \mathrm{~N}_{2} \mathrm{O}_{3}\right)$, que é incorporada tanto nas células vivas, quanto nas mortas. Este corante é utilizado numa concentração de $2 \%$ em uma solução de $4 \%$ de formaldeído, sendo posteriormente lavadas em água corrente até a eliminação total do excesso de corante [63, 78]. 


\subsection{Determinação do tempo de vida celular (life-span)}

Por meio da propagação dos queratinócitos em cultura (vide 4.3.2), até o final da vida útil, obtivemos a life-span, ou seja, o tempo de vida que esses queratinócitos foram capazes de atingir.

Concomitantemente a cada nova passagem, foi realizado o teste denominado de Eficiência de Formação de Colônia (vide 4.4).

Os resultados fornecidos por esses dois testes foram utilizados no seguinte cálculo (Equação 1), para se chegar ao número de gerações que essas células foram capazes de obter:

Equação 1:

$\mathrm{x}=3322 \log \underline{N}$

$N_{O}$

Onde: x é o número de gerações

$N$ é o número total de células obtidas após cada tripsinização

$N_{0}$ é o número de células semeadas multiplicadas pela CFE correspondente [63].

\subsection{Confecção dos epitélios}

Em duas placas de cultura contendo 24 poços $\left(1,88 \mathrm{~cm}^{2}\right)$, foram semeados $12 \times 10^{3}$ queratinócitos em cada poço, sobre uma camada de fibroblastos murinos 3T3 Swiss albino, numa concentração de $6 \times 10^{4}$ (vide 4.3.1.2) (previamente irradiados a $60 \mathrm{~Gy}$ ). Em uma das placas os queratinócitos foram provenientes do método explante, e na outra placa os queratinócitos foram provenientes do método enzimático. Tanto na placa correspondente ao método enzimático, quanto na placa correspondente ao método do explante, foram cultivados poços com $12 \times 10^{4}$ queratinócitos (alta densidade), ou seja, sem a utilização da camada de sustentação.

As condições para ambas as placas foram idênticas, com meio de cultura do tipo K-, inicialmente para os poços onde foram utilizadas as camadas de sustentação e diretamente com $\mathrm{K}+$, quando as células foram cultivadas em alta 
densidade. Essas células se mantiveram com troca de meio, inicialmente a cada dois dias, e após atingirem a confluência, a troca de meio passou a ser diariamente. Após o primeiro dia de confluência, um ou dois poços foram removidos, por meio da ação enzimática da dispase a 0,25\% (Protease Neutra grau II, Boehringer-Manheim, Alemanha), durante uma hora a $37^{\circ} \mathrm{C}$. O mesmo procedimento foi repetido sucessivamente durante alguns dias após a confluência, a saber: segundo, quarto, sétimo, décimo segundo, décimo quinto, décimo oitavo, vigésimo primeiro e vigésimo oitavo dias. Nos poços onde foram realizados os cultivos em alta densidade, o mesmo procedimento foi realizado nos: primeiro, sétimo, décimo quarto e vigésimo primeiro dias. Após o registro fotográfico das amostras, esses epitélios foram conservados em solução de formaldeído a 10\%.

\subsection{Preparação das lâminas para análise histológica dos epitélios}

As lâminas contendo os cortes histológicos provenientes dos epitélios formados, após a confluência das células, foram confeccionadas segundo protocolo abaixo.

Após a fixação desses epitélios em solução de formaldeído a 10\% (6), estes foram desidratados, passando por várias cubas de vidro contendo: etanol a $70 \%$, etanol a 95\%, etanol absoluto (três vezes) e xilol (três vezes).

Cada passagem teve a duração de uma hora.

Em aparelho auto-inclusor de parafina (Tissue-Tek, Sakura), o material foi colocado em moldes retangulares (denominados cassetes), contendo parafina fundida a $60^{\circ} \mathrm{C}$.

Em micrótomo rotativo (Leica RM 2045) com os blocos de parafina fixados, foram realizados os cortes histológicos. Estes, com espessura de $4 \mu \mathrm{m}$, foram colocados sobre uma lâmina de vidro, as quais foram posteriormente incubadas em uma estufa à $60^{\circ} \mathrm{C}$, para a remoção da parafina.

Em seguida o material passou por várias cubas de vidro, contendo: xilol (duas vezes), etanol absoluto (duas vezes), etanol a 95\% (duas vezes) e etanol a $70 \%$.

Cada passagem dura em média cinco minutos. 
Após a imersão da lâmina diretamente no corante hematoxilina de Harris por cinco minutos, procedeu-se a lavagem em água corrente, passando em seguida por uma cuba de vidro contendo etanol a 95\%.

Em seguida a lâmina foi imersa no corante eosina por 30 segundos.

Antes de proceder à montagem das mesmas, estas passaram por cubas contendo: etanol a 70\%, etanol a 95\% (duas vezes), etanol absoluto (três vezes) e xilol (três vezes).

A montagem destas lâminas foi feita em fita de polietileno, em aparelho próprio, de nome Tissue-Tek, SCA 4770 (Sakura) [50].

\subsection{Análise estatística dos dados obtidos}

No presente trabalho foi feita uma análise exploratória, com os resultados obtidos, por meio dos experimentos comparativos entre os métodos: enzimático e explante, para obtenção de células da mucosa bucal humana.

Por meio da análise podemos determinar as diferenças entre os dois métodos estudados, e se esta diferença é significativa estatisticamente ou não.

A partir da quantidade de dados obtidos por meio dos resultados dos experimentos aplicou-se uma análise estatística. Um dos métodos para a análise aplicado foi o teste de Wilcoxon, pelo fato deste ser um teste não paramétrico e ser o que julgamos mais adequado, neste caso que não temos determinadas as restrições garantidas, para aplicar outros testes paramétricos. Além desses resultados acompanhados dos p-valores respectivos, também apresentamos os dados em forma de gráfico, onde a área sombreada é proporcional à diferença entre os resultados obtidos. Também foi aplicado o teste de significância $t$ de student, onde foi possível aplicar testes paramétricos [21]. 


\section{5. RESULTADOS}

\subsection{Tamanho dos fragmentos}

Após a desinfecção e limpeza dos fragmentos coletados, estes foram medidos para posterior uso dos mesmos nos cálculos de rendimento celular.

\begin{tabular}{|c|c|}
\hline $\begin{array}{l}\text { Pacientes Voluntários } \\
\qquad \mathrm{n}=35\end{array}$ & $\begin{array}{l}\text { Área dos fragmentos } \\
\left(\mathrm{cm}^{2}\right)\end{array}$ \\
\hline V 01 & 0,46 \\
\hline V 02 & 0,30 \\
\hline$\vee 03$ & 1,80 \\
\hline V 04 & 1,15 \\
\hline V 05 & 1,40 \\
\hline V 06 & 0,46 \\
\hline V 07 & 0,24 \\
\hline V 08 & 0,16 \\
\hline V 09 & 1,23 \\
\hline V 10 & 0,22 \\
\hline V 11 & 2,00 \\
\hline V 12 & 0,30 \\
\hline V 13 & 0,45 \\
\hline V 14 & 0,72 \\
\hline V 15 & 1,05 \\
\hline V 16 & 1,23 \\
\hline V 17 & 0,45 \\
\hline V 18 & 0,65 \\
\hline V 19a & 1,42 \\
\hline$\vee 19 b$ & 0,28 \\
\hline V 20 & 0,20 \\
\hline V 21 & 0,45 \\
\hline V 22 & 0,24 \\
\hline$\vee 23$ & 0,12 \\
\hline V 24 & 0,51 \\
\hline V 25 & 0,24 \\
\hline V 26 & 0,32 \\
\hline$\vee 27$ & 0,40 \\
\hline$\vee 28$ & 0,56 \\
\hline V 29 & 0,20 \\
\hline$\vee 30$ & 0,44 \\
\hline V 31 & 0,48 \\
\hline V 32 & 0,24 \\
\hline V 33 & 2,30 \\
\hline V 34 & 0,15 \\
\hline $\begin{array}{c}\text { Média e DP } \\
\text { Variação min e max }\end{array}$ & $\begin{array}{l}0,65 \text { e } 0,57 \\
0,12 \text { e } 2,00\end{array}$ \\
\hline
\end{tabular}


Na TAB. 3 são mostradas as medidas resumo dos fragmentos.

TABELA 3- Medidas resumo dos fragmentos $\left(\mathrm{em} \mathrm{cm}^{2}\right)$

\begin{tabular}{cccccc} 
Mínimo & IQ & Mediana & Média & IIIQ & Máximo \\
\hline 0,12 & 0,24 & 0,45 & 0,65 & 0,88 & 2,3 \\
\hline
\end{tabular}

IQ (primeiro quantil)= valor da área abaixo da qual fica $25 \%$.

IIIQ (terceiro quantil)= valor da área abaixo da qual fica $75 \%$.

Na FIG.11 é mostrada em formato de histograma a área total e média dos fragmentos.

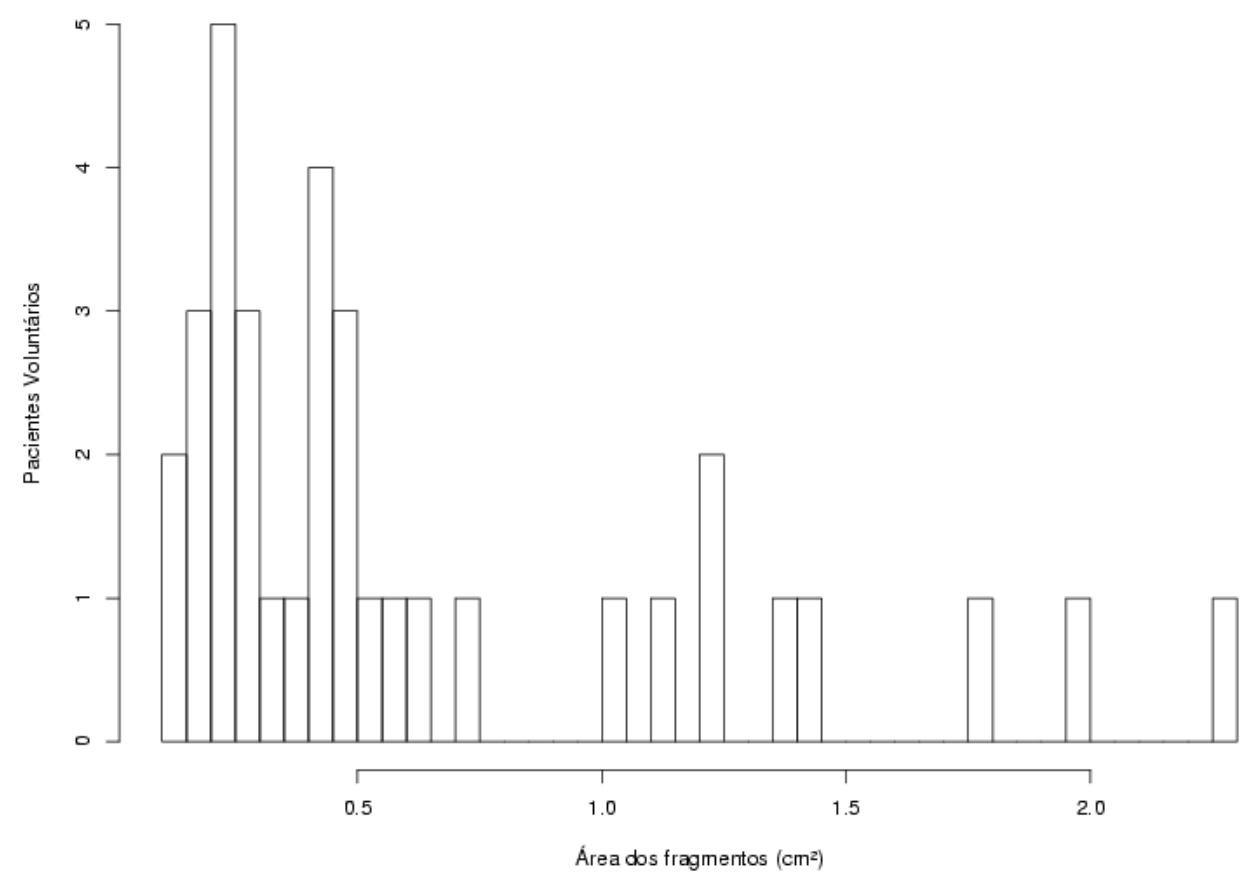

FIGURA 11- área total e média dos fragmentos

\subsection{Resultados obtidos a partir da primeira colheita de queratinócitos}

\subsubsection{Morfologia da P0}

Comparação do aspecto morfológico das células provenientes de ambos os métodos ao final da passagem (P0). 
Na FIG.12, são mostradas as células em estágio de sub-confluência, no método enzimático e no momento em que foram retiradas da placa no método do explante.
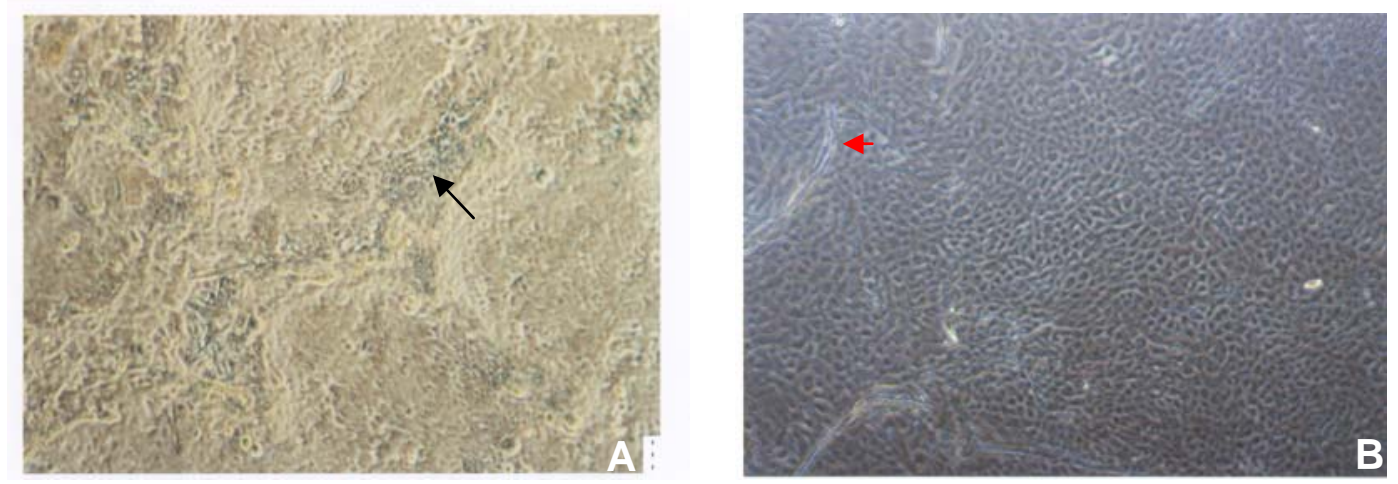

FIGURA- 12. Imagens fotográficas dos queratinócitos em cultura. (A) células em estágio de sub-confluência (método enzimático). Feeder Layer remanescente ( ) (B) células no momento em que foram retiradas da placa (método do explante) Início da diferenciação $(\varangle)$. Aumento de 100 vezes, com filtro azul.

\subsubsection{Tempo necessário para a obtenção da primeira colheita dos queratinócitos.}

Na TAB 4 é apresentado o tempo necessário para se obter a primeira colheita dos queratinócitos em ambos os métodos. No método enzimático, quando as células atingiram a sub-confluência e no método do explante, quando as células, próximas ao fragmento, apresentaram aspecto de início do processo de diferenciação, aumentando de tamanho. Na FIG. 13, a seguir, são apresentadas, em forma de gráfico, as diferenças referentes ao tempo, para esta primeira colheita dos queratinócitos nos dois métodos avaliados. No eixo X estão localizadas as amostras e no eixo Y está localizado o tempo, em dias. A diferença entre os dois métodos esta representada pela área cinza, a qual indica o número de dias em que as duas metodologias diferem para cada voluntário. 
TABELA 4- Tempo necessário para a obtenção da primeira colheita dos queratinócitos nos métodos: enzimático e explante

\begin{tabular}{ccc}
$\begin{array}{c}\text { Voluntários } \\
\mathbf{n = 2 0}\end{array}$ & $\begin{array}{c}\text { Mét. Enzimático } \\
\text { (Dias) }\end{array}$ & $\begin{array}{c}\text { Mét. Explante } \\
\text { (Dias) }\end{array}$ \\
\hline V 01 & 13 & 13 \\
V 02 & 14 & 14 \\
V 03 & 10 & 19 \\
V 05 & 10 & 12 \\
V 08 & 16 & 16 \\
V 10 & 13 & 16 \\
V 11 & 08 & 10 \\
V 13 & 10 & 15 \\
V 15 & 11 & 14 \\
V 16 & 11 & 14 \\
V 17 & 11 & 13 \\
V 18 & 11 & 14 \\
V 19a & 14 & 15 \\
V 19b & 12 & 12 \\
V 20 & 11 & 17 \\
V 23 & 14 & 15 \\
V 27 & 18 & 14 \\
V 32 & 09 & 11 \\
V 33 & 10 & 21 \\
V34 & 12 & 09 \\
\hline Média & $\mathbf{1 1 , 9}$ & $\mathbf{1 4 , 2}$ \\
DP & $\mathbf{2 , 3 6}$ & $\mathbf{2 , 7 6}$ \\
\hline
\end{tabular}

\section{$P$-valor $=0.0088$}

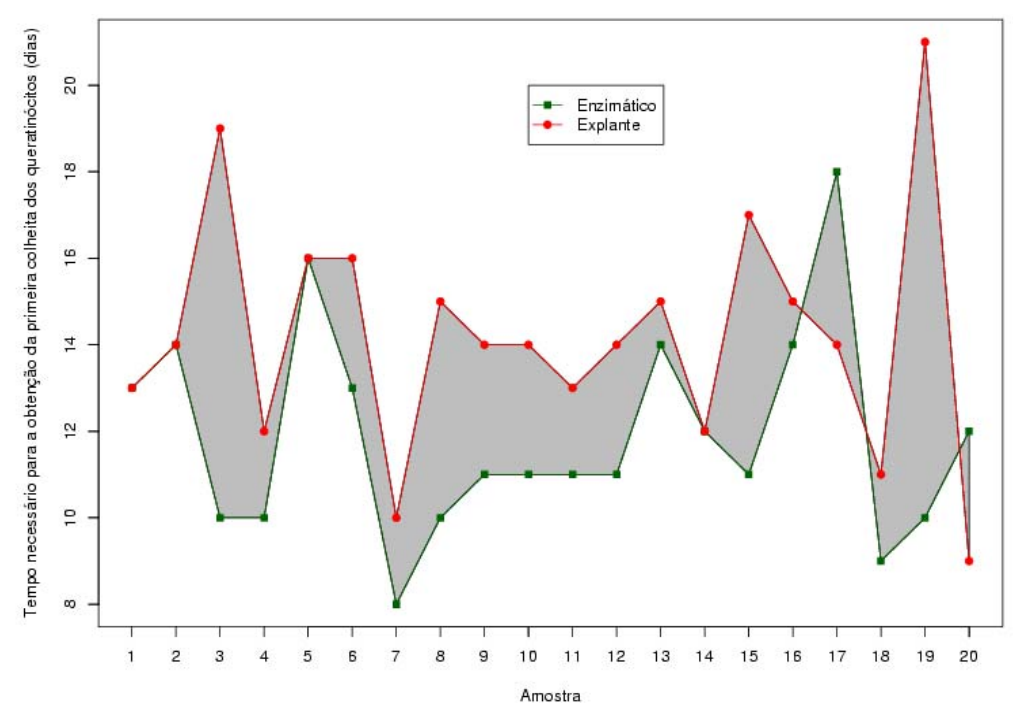

FIGURA 13- No gráfico é mostrada a diferença (área cinza) entre os tempos necessários para a primeira colheita dos queratinócitos entre os métodos avaliados. 


\subsubsection{Rendimento celular inicial para a primeira colheita dos queratinócitos.}

$\mathrm{Na}$ TAB. 5 são mostrados os dados do rendimento celular obtidos em cada método na primeira colheita dos queratinócitos. Para cada método foi utilizada a metade da área total do fragmento inicial. Para a retirada dos queratinócitos, no método enzimático as células se encontravam na subconfluência e no método do explante os queratinócitos se encontravam no início do processo de diferenciação.

TABELA 5- Rendimento celular da primeira colheita dos queratinócitos

\begin{tabular}{|c|c|c|}
\hline Pacientes & Método Enzimático & Método Explante \\
\hline $\begin{array}{c}\text { Voluntários } \\
\text { n=31 }\end{array}$ & $\begin{array}{c}\text { Rendimento celular } \\
\text { por } \mathrm{cm}^{2} \\
\left(\times 10^{5}\right)\end{array}$ & $\begin{array}{c}\text { Rendimento celular } \\
\text { por } \mathrm{cm}^{2} \\
\left(\times 10^{5}\right)\end{array}$ \\
\hline V 01 & 34,80 & 3,04 \\
\hline V 02 & 8,33 & 7,00 \\
\hline V 03 & 53,61 & 5,46 \\
\hline V 05 & 25,35 & 7,08 \\
\hline V 06 & 165,00 & $*$ \\
\hline V 07 & 4,30 & * \\
\hline V 08 & 4,28 & 42,80 \\
\hline V 09 & 30,70 & * \\
\hline V 10 & 143,00 & 10,90 \\
\hline V 11 & 24,70 & 8,37 \\
\hline V 12 & $\star *$ & 2,00 \\
\hline V 13 & 48,00 & 24,00 \\
\hline V 14 & 131 & * \\
\hline V 15 & 21,10 & 1,66 \\
\hline V 16 & 86,30 & 2,44 \\
\hline V 17 & 91,10 & 1,33 \\
\hline V 18 & 71,40 & 1,14 \\
\hline V 19a & 9,32 & 9,18 \\
\hline V 19b & 49,80 & 5,00 \\
\hline V 20 & 18,50 & 2,20 \\
\hline V 21 & 24,20 & * \\
\hline V 22 & 113,00 & * \\
\hline V 23 & 35,00 & 0,83 \\
\hline V 26 & 12,50 & * \\
\hline V 27 & 16,00 & 2,60 \\
\hline V 28 & 10,50 & * \\
\hline V29 & 9,00 & 0,50 \\
\hline V30 & 10,00 & * \\
\hline V32 & 35 & 2,91 \\
\hline V33 & 0,10 & 1,75 \\
\hline V34 & 19,33 & 1,30 \\
\hline Média & 43,50 & 6,52 \\
\hline DP & 43,90 & 9,41 \\
\hline $\begin{array}{l}\text { Não houve lib } \\
\text { *) Não houve c } \\
\text { icial }\end{array}$ & $\begin{array}{l}\text { a de células a partir do } \\
\text { volvimento das células }\end{array}$ & litura após a tripsinização \\
\hline P-valor $=0,($ & 331 & \\
\hline
\end{tabular}




\subsection{Eficiência de formação de colônias (EFC)}

A eficiência de formação de colônias foi utilizada tanto para comparar os tipos de células obtidas por cada método na primeira passagem, quanto para visualizar a evolução das mesmas nas passagens subseqüentes.

Nas FIG. 14 são mostradas imagens macroscópicas das placas contendo as colônias coradas após a finalização do teste de EFC.
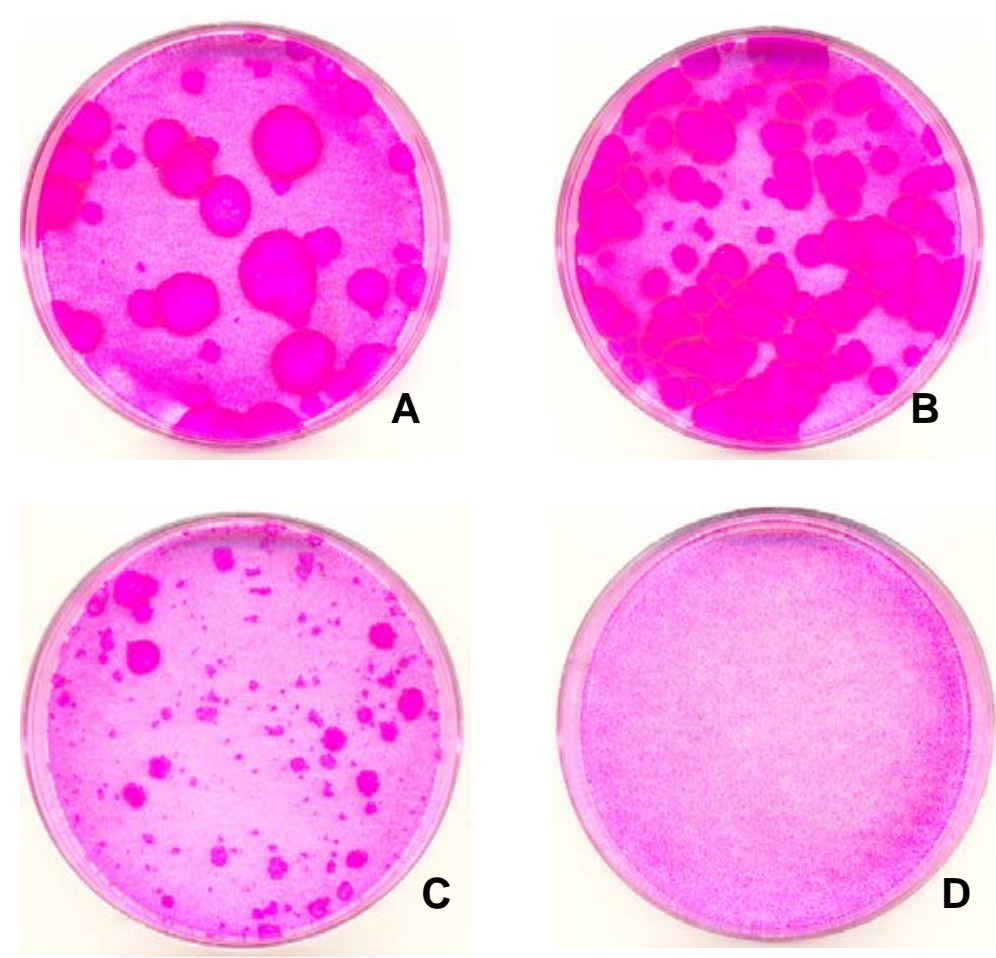

FIGURA 14- Imagens macroscópicas das placas contendo os tipos de colônias encontradas após a realização do teste de EFC. A) Colônias em desenvolvimento; B) Colônias em desenvolvimento perto de 100\%; C) Colônias em desenvolvimento e abortivas; D) Ausência de colônias. 
Na FIG. 15 são mostradas as imagens microscópicas da aparência de colônias em desenvolvimento e abortivas.
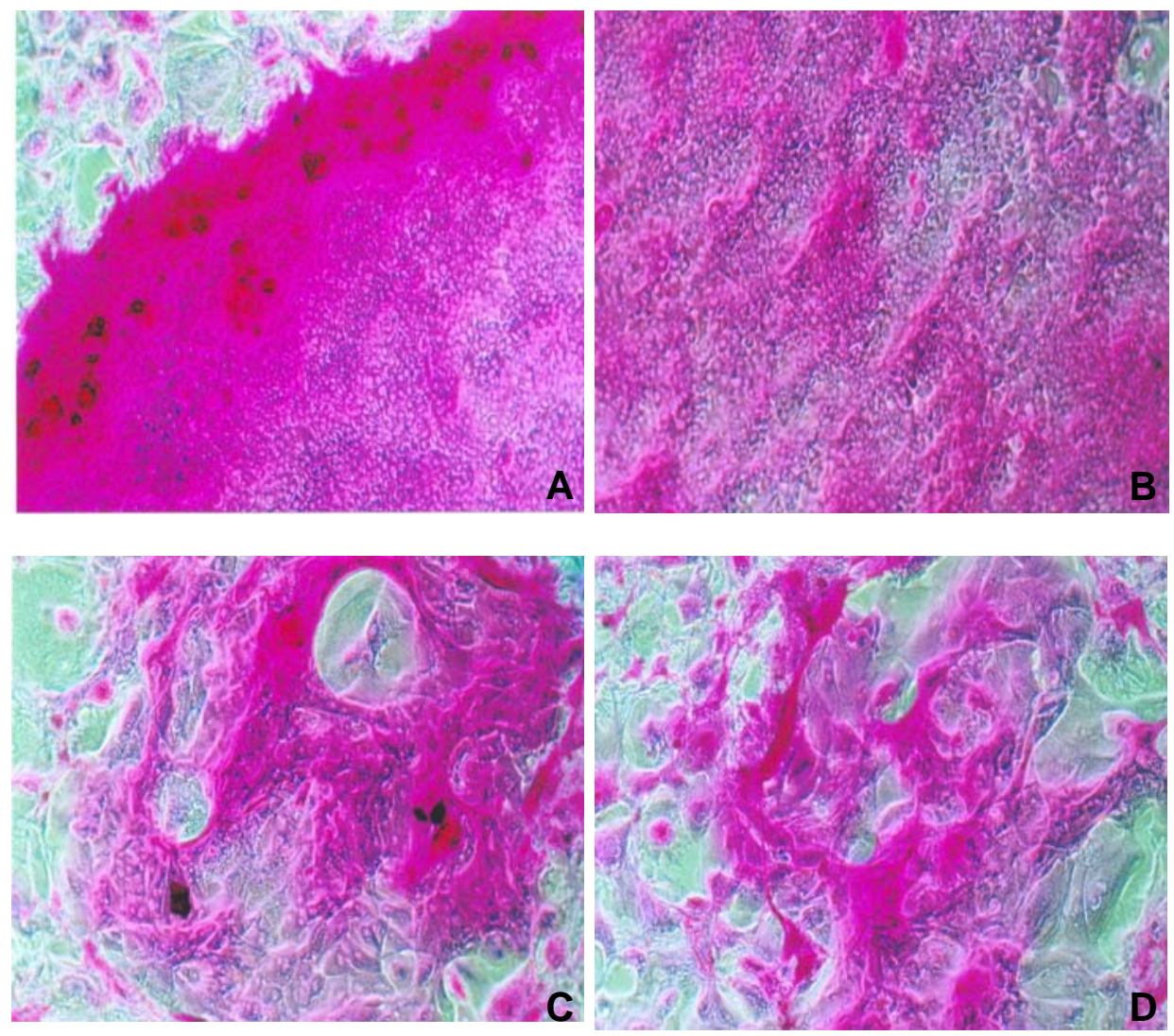

FIGURA 15- Imagens microscópicas da aparência de colônias em desenvolvimento e colônias abortivas. A) Borda de uma colônia em desenvolvimento; B) Centro de uma colônia em desenvolvimento; D) Colônia abortiva. D) Colônia abortiva. Aumento de 100 vezes, filtro azul.

\subsubsection{Eficiência de formação de colônias (EFC) da primeira passagem.}

$\mathrm{Na}$ TAB. 6 são apresentadas as porcentagens das colônias, em desenvolvimento e abortivas, obtidas pelo teste: Eficiência de Formação de Colônias, da primeira passagem dos queratinócitos em cultura nos métodos: enzimático e explante. Na FIG. 16, a seguir, é mostrada em forma de gráfico a comparação entre a quantidade de colônias totais em ambos métodos comparados. 
TABELA 6- Porcentagem das colônias obtidas no teste EFC da P1

\begin{tabular}{|c|c|c|c|c|}
\hline $\begin{array}{c}\text { Voluntários } \\
\mathbf{n}=10\end{array}$ & $\begin{array}{c}\text { Mét. E } \\
\text { col. totais } \\
\%\end{array}$ & $\begin{array}{l}\text { imático } \\
\text { col. abort. } \\
\%\end{array}$ & $\begin{array}{c}\text { Mét. E } \\
\text { col. totais } \\
\%\end{array}$ & $\begin{array}{l}\text { xplante } \\
\text { col. abort. } \\
\%\end{array}$ \\
\hline V 01 & 43 & 1,5 & 38 & 15,5 \\
\hline V 02 & 0,5 & & & 0,5 \\
\hline V 03 & 100 & & 53 & 11 \\
\hline V 05 & 78 & & 20 & 13 \\
\hline V 08 & 28 & & 17 & 0,5 \\
\hline V 10 & 29 & 15,5 & 35,5 & \\
\hline V 11 & 74 & & 58 & \\
\hline V 13 & 53 & & 62 & \\
\hline V 15 & 80 & & 4,6 & \\
\hline V 16 & 31,8 & & 41,6 & \\
\hline
\end{tabular}

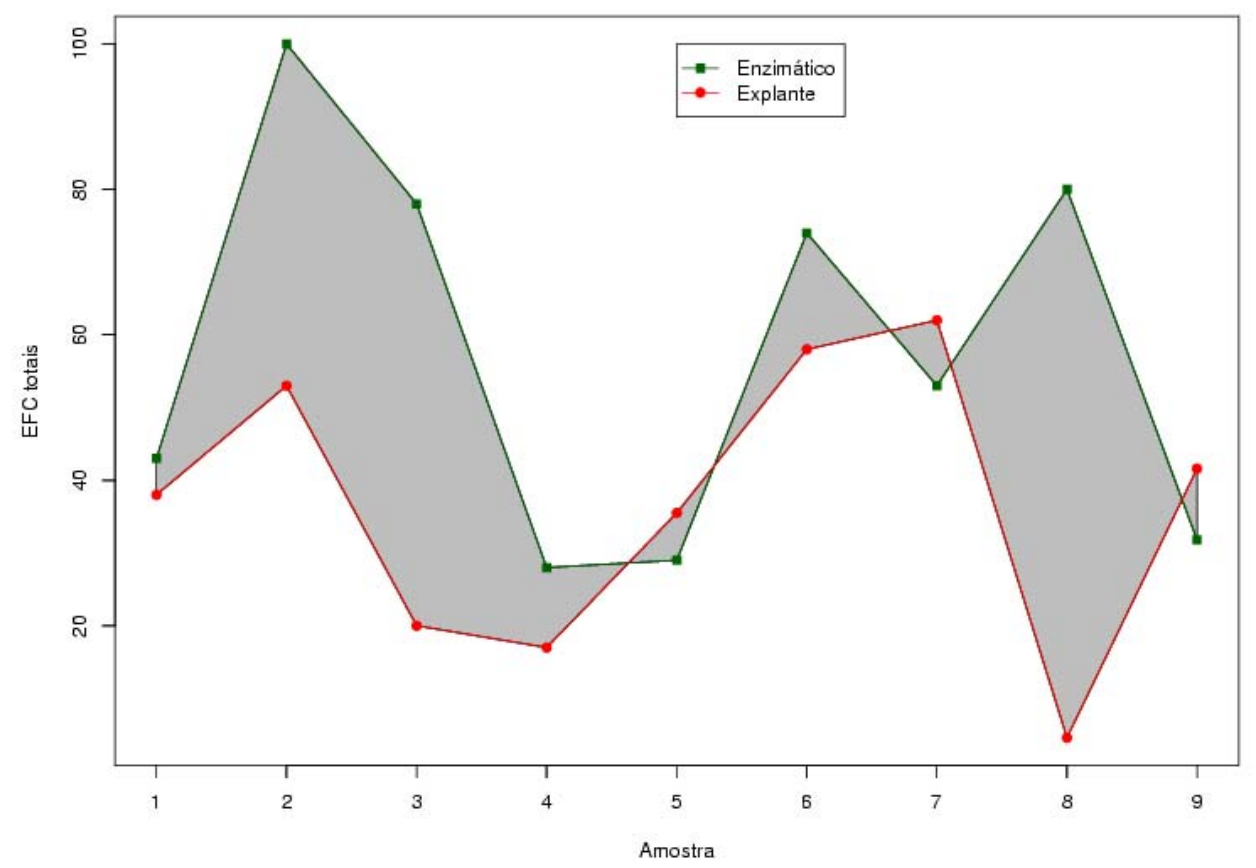

FIGURA 16- No gráfico é mostrada a comparação entre a quantidade de colônias totais em ambos os métodos comparados. Essa diferença é representada pela área cinza. 


\subsubsection{Evolução de células clonogênicas.}

Nas FIG. 17 a 26 estão mostrados os gráficos obtidos a partir do número de colônias em desenvolvimento, colônias abortivas e colônias totais (APÊNDICE B), determinadas pelo teste de EFC (vide 4.4), referentes aos dois métodos avaliados para cada voluntário. Esta avaliação do aspecto e tamanho das colônias obtidas, no presente trabalho, determinou a clonogenicidade das células em cultura.

Nas FIG. 21 e 23 não houve obtenção de células para o método do explante e na FIG. 26 não houve continuidade do cultivo das células obtidas pelo método do explante, por falta de rendimento celular.
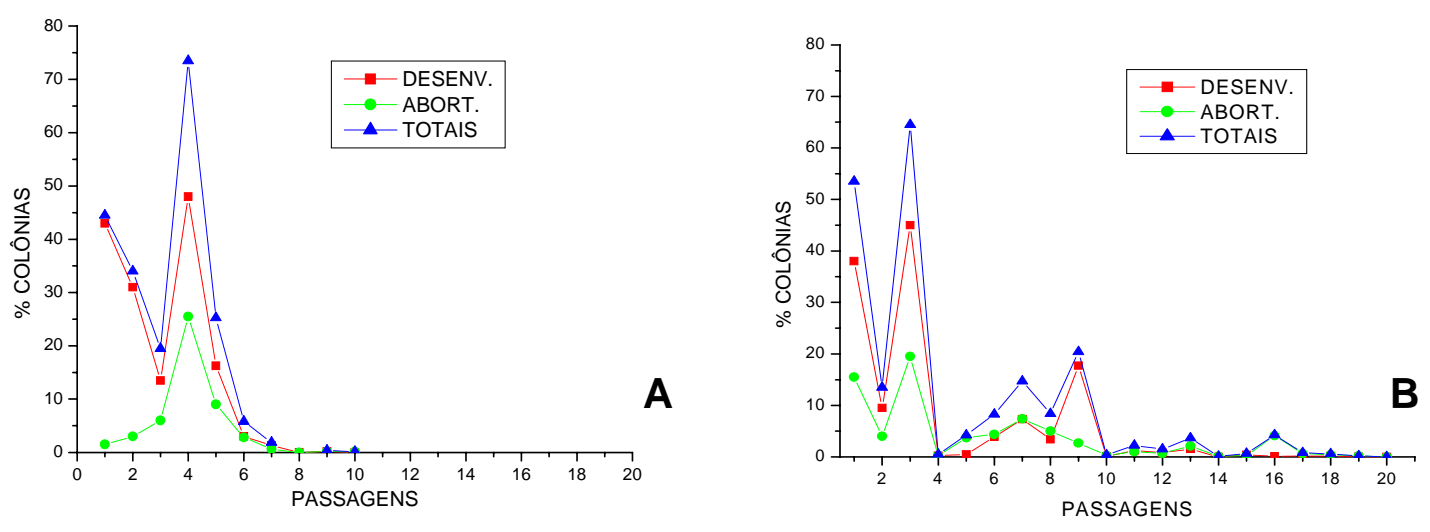

FIGURA 17- Evolução das células clonogênicas do voluntário 1: A) Método enzimático, B) Método Explante
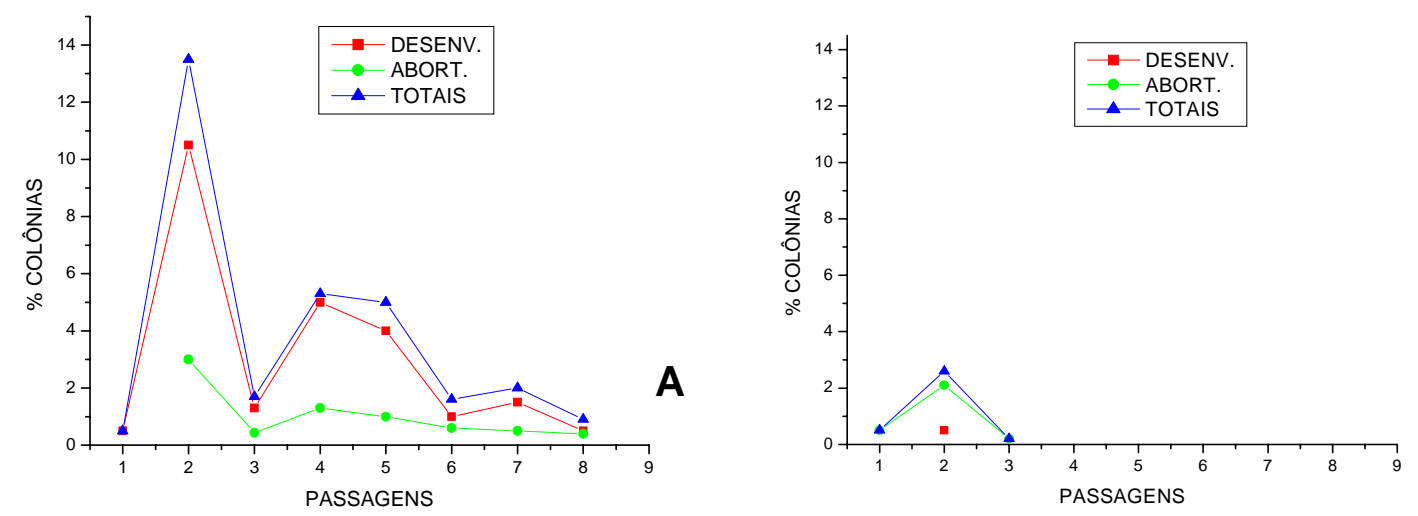

B

FIGURA 18- Evolução das células clonogênicas do voluntário 2: A) Método enzimático, B) Método Explante 

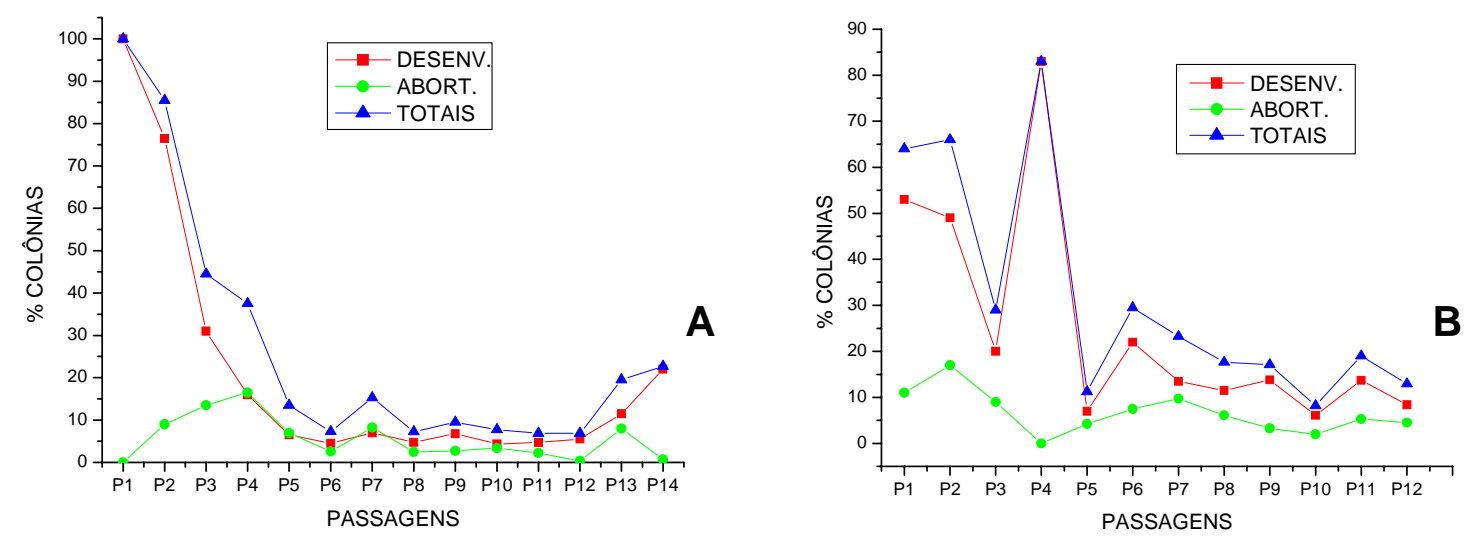

FIGURA 19- Evolução das células clonogênicas do voluntário 3: A) Método enzimático, B) Método Explante
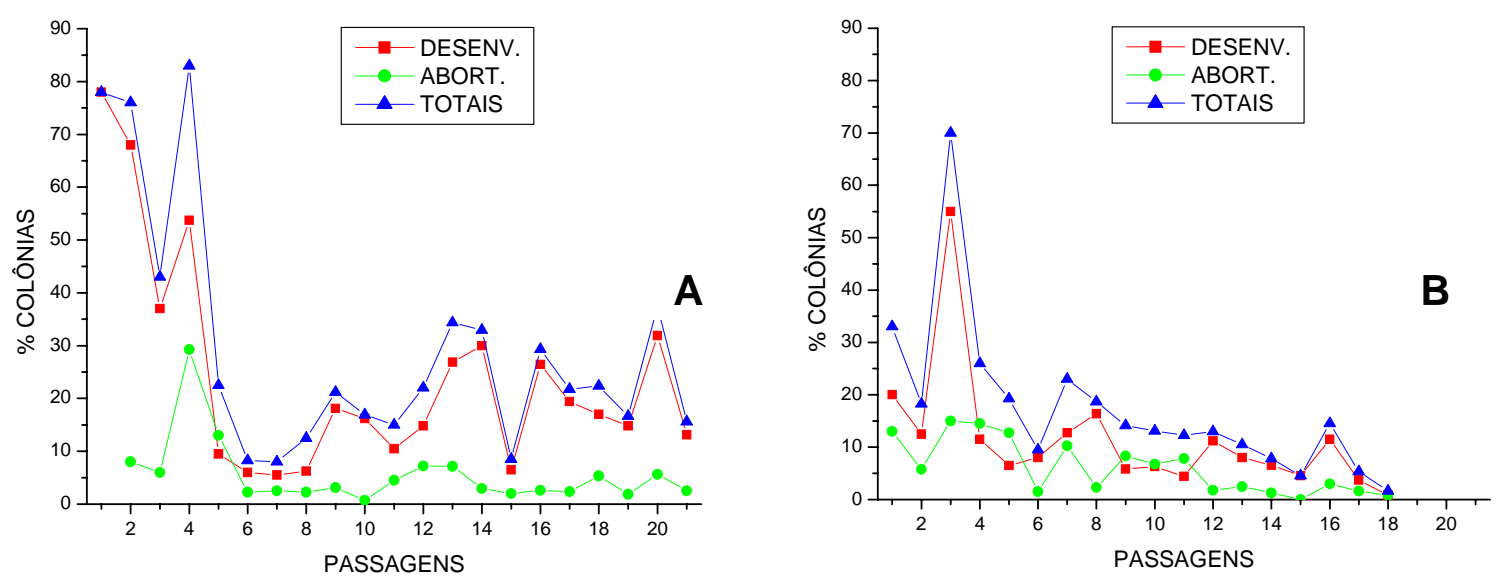

FIGURA 20- Evolução das células clonogênicas do voluntário 5: A) Método enzimático, B) Método Explante

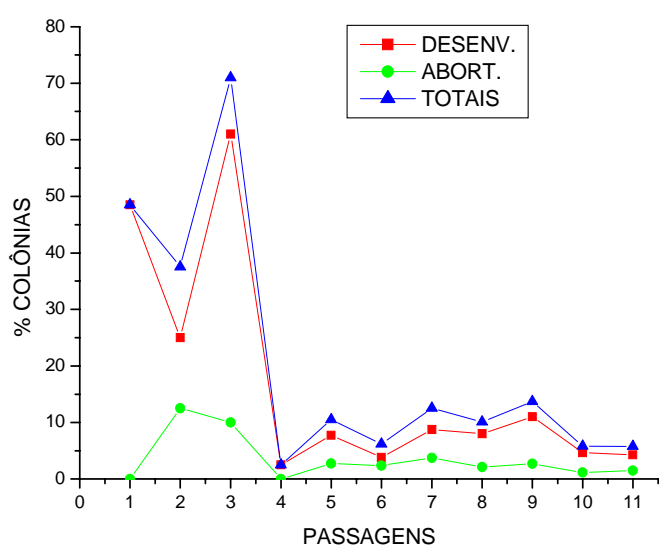

FIGURA 21- Evolução das células clonogênicas do voluntário 6. Método enzimático 

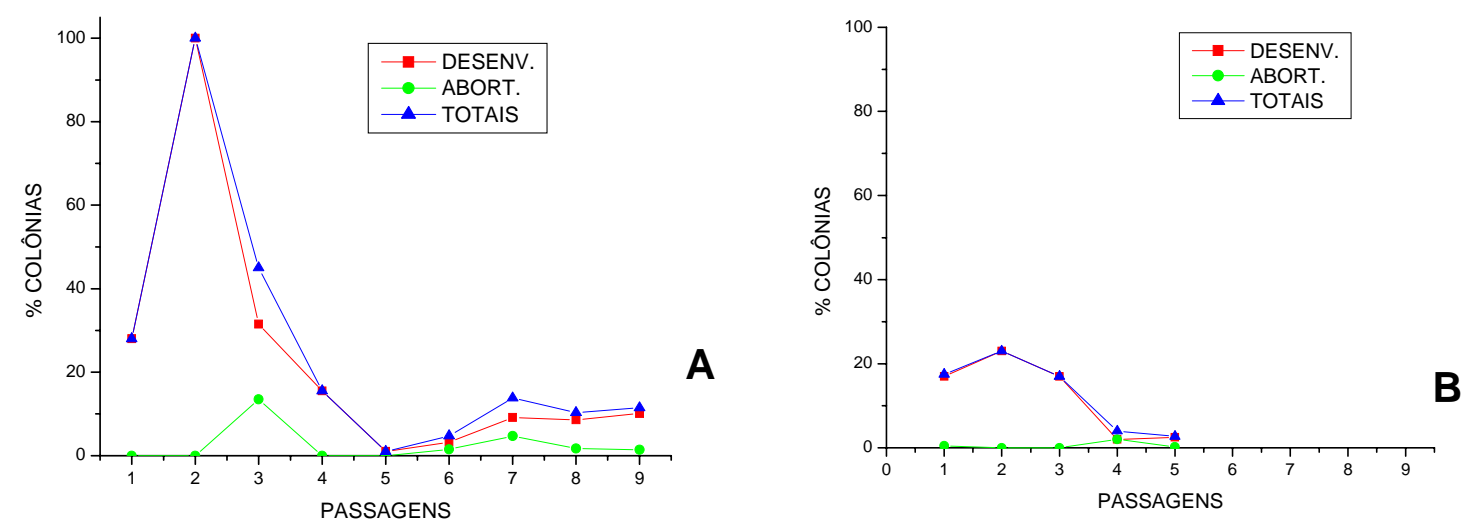

FIGURA 22- Evolução das células clonogênicas do voluntário 8: A) Método enzimático, B) Método Explante

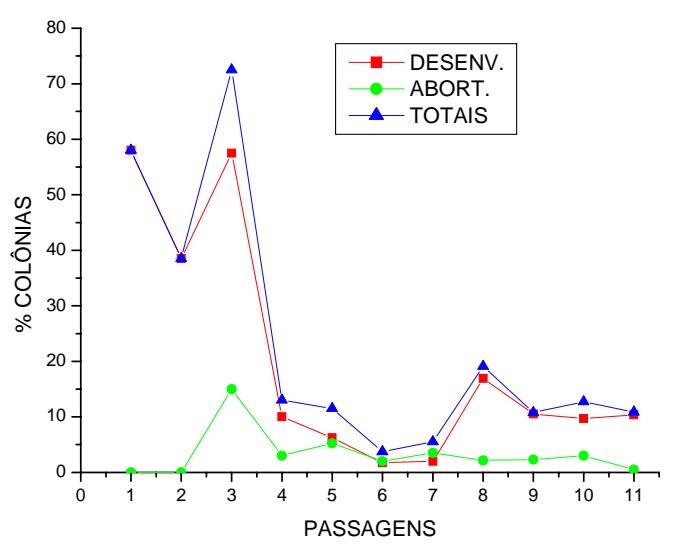

FIGURA 23- Evolução das células clonogênicas do voluntário 9. Método enzimático
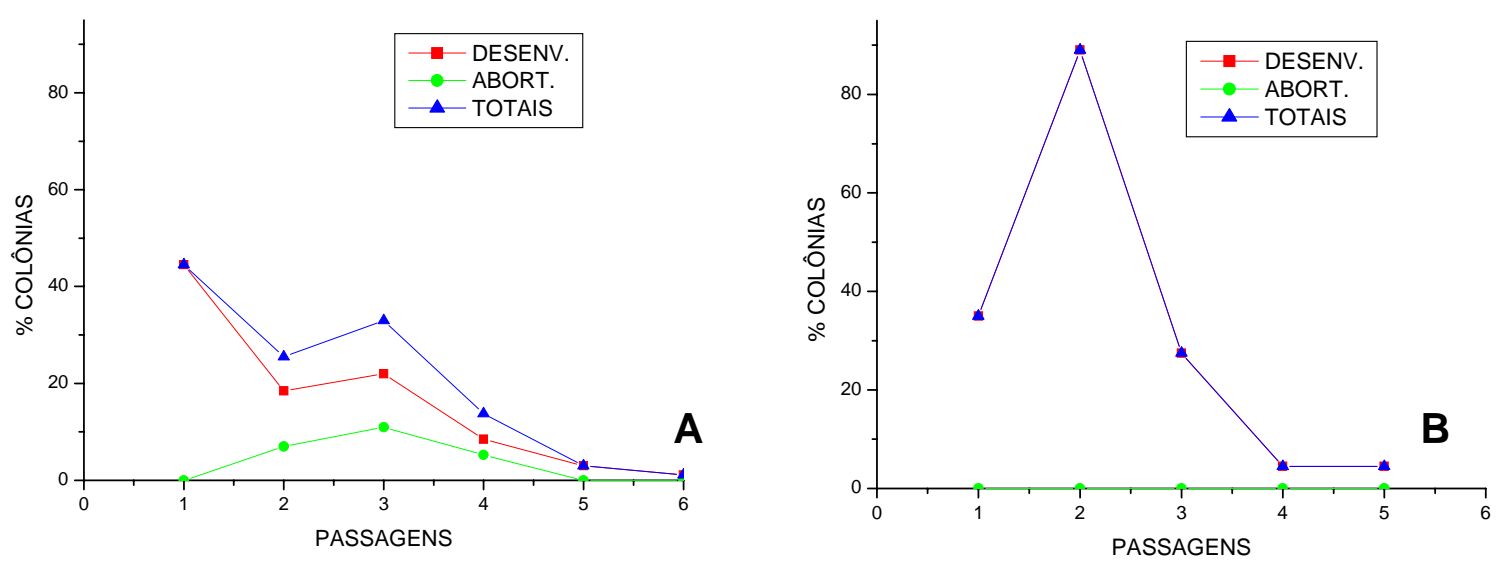

FIGURA 24- Evolução das células clonogênicas do voluntário 10: A) Método enzimático, B) Método Explante 

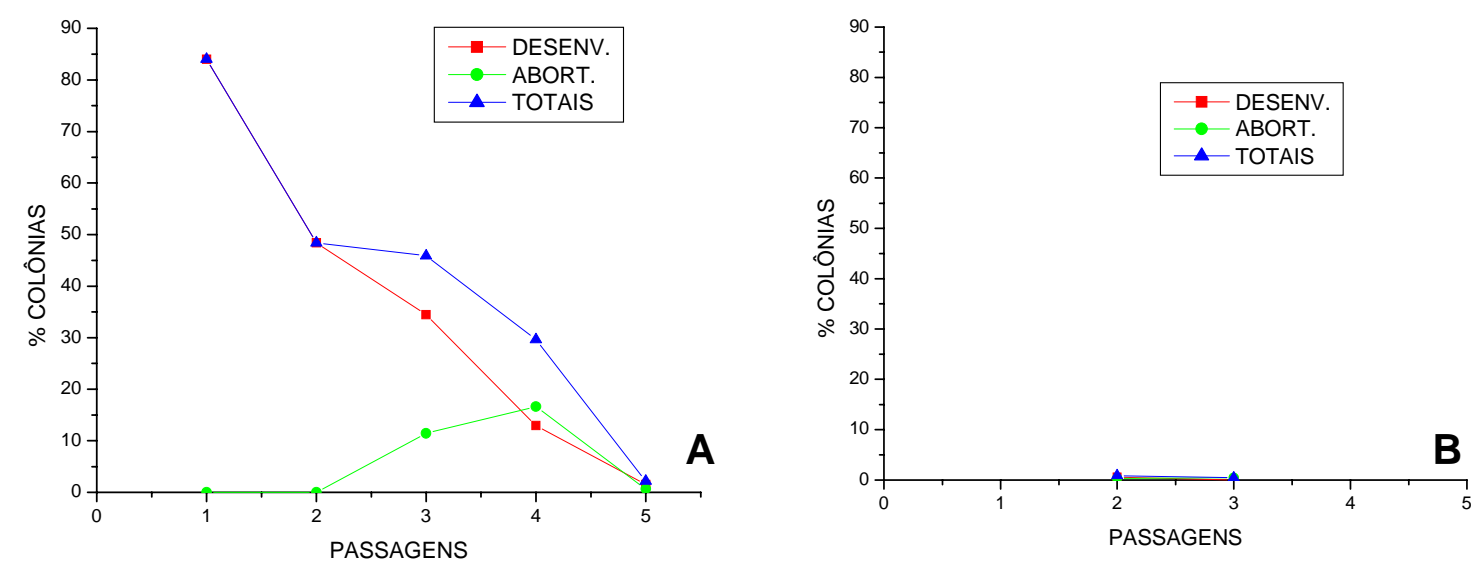

FIGURA 25- Evolução das células clonogênicas do voluntário 32: A) Método enzimático, B) Método Explante

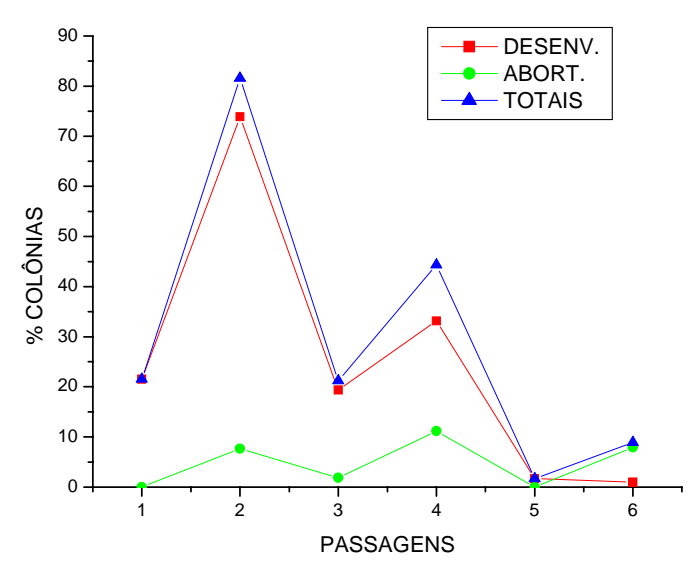

FIGURA 26- Evolução das células clonogênicas do voluntário 34. Método enzimático

\subsection{Tempo de vida celular (life-span) comparativo.}

A seguir nas TAB. 7 a 20 são apresentadas as quantidades de células obtidas na sub-confluência de cada passagem e os respectivos números de duplicações necessários para atingir este estágio. O número de duplicações foi obtido por meio da Equação 1 (vide 4.5) utilizando os dados de: quantidade de células, dias transcorridos, e porcentagem do total de colônias obtidas em cada passagem por meio do teste de EFC (APÊNDICE C). Abaixo nas FIG. 27, 29, 30, 32, 34, 35, 37 a 44 são mostrados os números de duplicações e tempo transcorridos, referentes a cada tabela. Nas FIG. 28, 31, 33 e 36 são mostradas em forma de gráfico a comparação entre as duplicações celulares proveniente do emprego dos dois métodos analisados. Nas TAB. 11 e 13 e nas FIG. 34 e 37 
estão apresentados e respectivamente mostrados, os resultados referentes somente ao método enzimático, por não ter havido liberação de células no método do explante (vide TAB. 4).

TABELA 7- Quantidade de células obtidas em cada passagem, número de duplicações e dias transcorridos: Voluntário 1

\begin{tabular}{|c|c|c|c|c|c|c|}
\hline \multirow[t]{2}{*}{ Passagens } & \multicolumn{2}{|c|}{ Enzimático } & \multirow[t]{2}{*}{ Dias } & \multicolumn{2}{|c|}{ Explante } & Dias \\
\hline & $\begin{array}{l}\text { Quantidade } \\
\text { de cels. } \\
\left(\times 10^{6}\right)\end{array}$ & $\begin{array}{l}\text { Número de } \\
\text { duplicações }\end{array}$ & & $\begin{array}{l}\text { Quantidade } \\
\text { de cels. } \\
\left(\times 10^{6}\right)\end{array}$ & $\begin{array}{l}\text { Número de } \\
\text { duplicações }\end{array}$ & \\
\hline P1 & 0,80 & 9,82 & 13 & 0,07 & 9 & 13 \\
\hline $\mathrm{P} 2$ & 1,70 & 14,88 & 17 & 0,52 & 12,71 & 20 \\
\hline P3 & 1,68 & 19,81 & 22 & 0,60 & 16,93 & 26 \\
\hline P4 & 1 & 21,16 & 30 & 0,25 & 18,85 & 32 \\
\hline P5 & 1 & 25,31 & 36 & 1 & 22,70 & 41 \\
\hline P6 & 1,45 & 32,69 & 43 & 1,13 & 31,10 & 49 \\
\hline P7 & 0,81 & 40,85 & 50 & 1,07 & 37,50 & 56 \\
\hline P8 & 0,42 & 50 & 57 & 1,40 & 43,47 & 60 \\
\hline P9 & 0,33 & 60,55 & 68 & 1,56 & 49,51 & 65 \\
\hline P10 & & & & 0,82 & 55,08 & 70 \\
\hline P11 & & & & 1,09 & 60,45 & 75 \\
\hline $\mathrm{P} 12$ & & & & 1,03 & 69,88 & 80 \\
\hline P13 & & & & 0,83 & 75,11 & 85 \\
\hline P14 & & & & 0,66 & 81,97 & 90 \\
\hline P15 & & & & 1,05 & 90,45 & 95 \\
\hline P16 & & & & 0,25 & 99,96 & 102 \\
\hline P17 & & & & 0,95 & 109,91 & 110 \\
\hline P18 & & & & 1,75 & 117,72 & 116 \\
\hline P19 & & & & 0,72 & 125,10 & 122 \\
\hline P20 & & & & 0,38 & 131,69 & 129 \\
\hline P21 & & & & 0,22 & 138,76 & 135 \\
\hline
\end{tabular}

$P$ valor - 0,01766664

Média de tempo de duplicação: Enzimático= 29,91 hs, Explante= 30,49 hs.

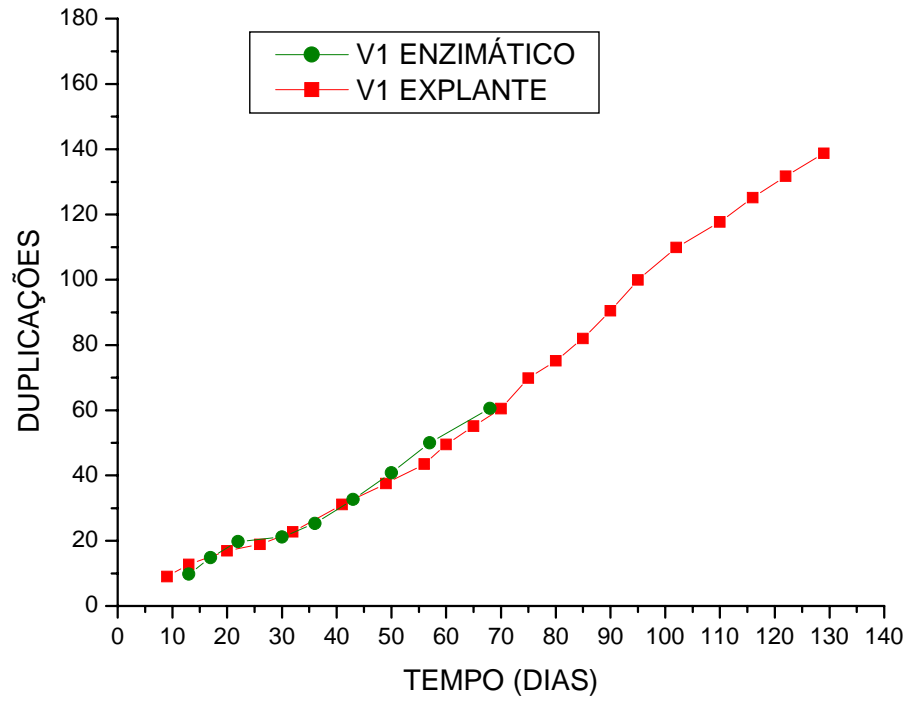

FIGURA 27- Número de duplicações de cada método ao longo dos dias: V1. 


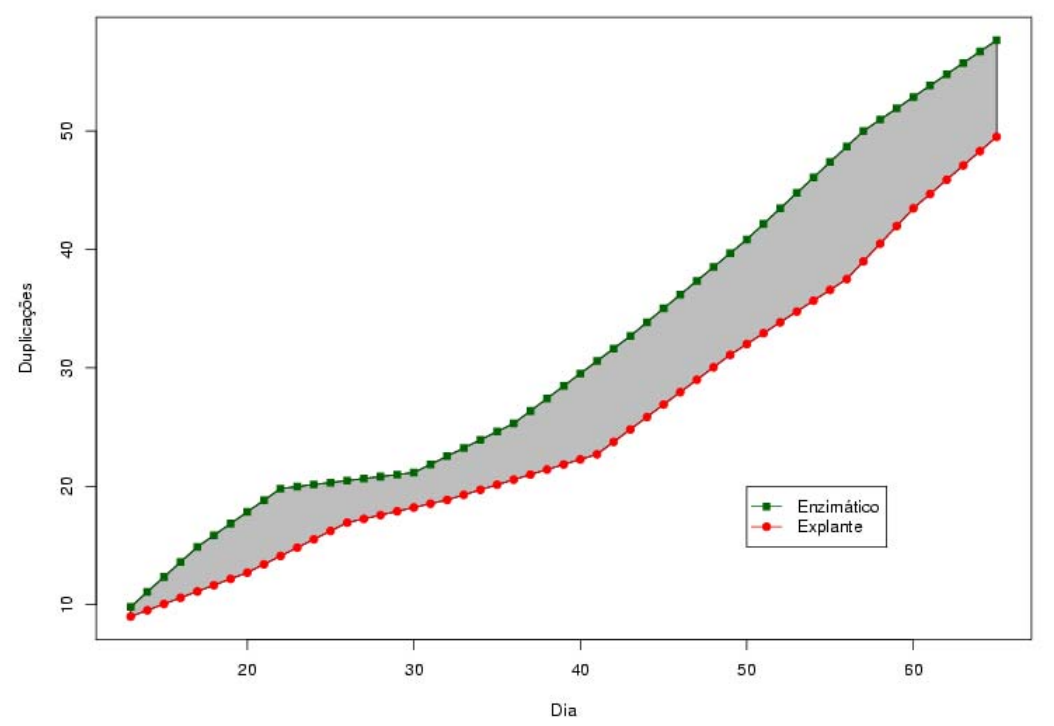

FIGURA 28- Comparações entre os dois métodos do número de duplicações celulares: $\mathrm{V} 1$.

TABELA 8- Quantidade de células obtidas em cada passagem, número de duplicações e dias transcorridos: Voluntário 2

\begin{tabular}{c|cccccc}
\hline Passagens & \multicolumn{2}{|c}{ Enzimático } & Dias & \multicolumn{2}{c}{ Explante } & Dias \\
\cline { 2 - 3 } & $\begin{array}{c}\text { Quantidade } \\
\text { de cels. } \\
\left(\times 10^{6}\right)\end{array}$ & $\begin{array}{c}\text { Número de } \\
\text { duplicações }\end{array}$ & & $\begin{array}{c}\text { Quantidade. } \\
\text { de cels. } \\
\left(\times 10^{6}\right)\end{array}$ & $\begin{array}{c}\text { Número de } \\
\text { duplicações }\end{array}$ & \\
P1 & 0,12 & 14,71 & 14 & 0,10 & 9 & 10 \\
P2 & 0,30 & 18,63 & 22 & 0,17 & 17,33 & 20 \\
P3 & 0,92 & 22,54 & 30 & 0,41 & 24,05 & 30 \\
P4 & 3 & 31,10 & 40 & & & \\
P5 & 1 & 38,16 & 46 & & & \\
P6 & 0,51 & 45,90 & 53 & & & \\
P7 & 0,34 & 52,75 & 58 & & & \\
\hline
\end{tabular}

Média de tempo de duplicação: Enzimático= 28,14 hs, Explante= 27,49 hs.

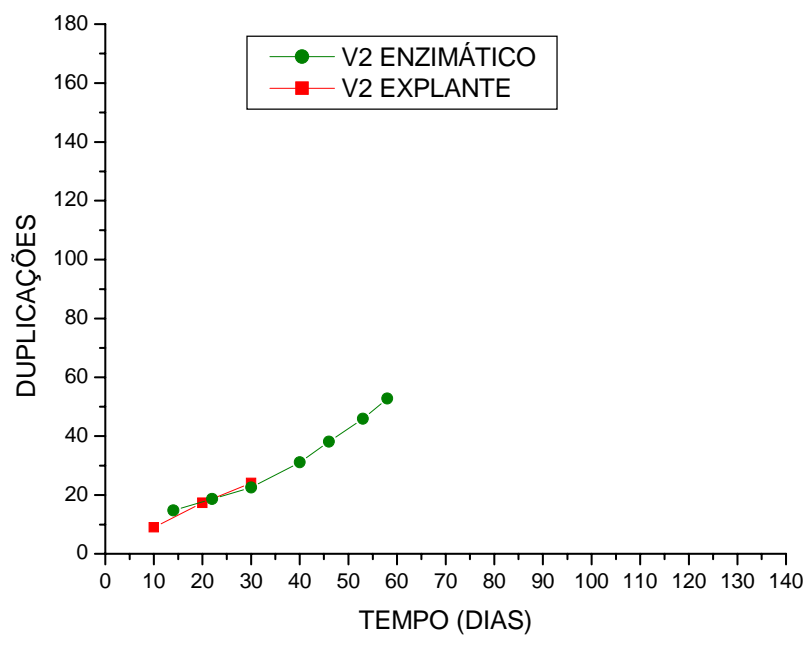

FIGURA 29- Número de duplicações de cada método ao longo dos dias: V2. 
TABELA 9- Quantidade de células obtidas em cada passagem, número de duplicações e dias transcorridos: Voluntário 3

\begin{tabular}{c|ccccccc}
\hline Passagens & \multicolumn{2}{|c}{ Enzimático } & Dias & \multicolumn{2}{c}{ Explante } & Dias \\
\cline { 2 - 3 } & $\begin{array}{c}\text { Quantidade } \\
\text { de cels. } \\
\left(\times 10^{6}\right)\end{array}$ & $\begin{array}{c}\text { Número de } \\
\text { duplicações }\end{array}$ & & $\begin{array}{c}\text { Quantidade } \\
\text { de cels. } \\
\left(\times 10^{6}\right)\end{array}$ & $\begin{array}{c}\text { Número de } \\
\text { duplicações }\end{array}$ & \\
P1 & 5,27 & 6,47 & 10 & 0,63 & 18 & 20 \\
P2 & 5,70 & 12,58 & 15 & 4,58 & 23,70 & 27 \\
P3 & 8,85 & 18,71 & 20 & 4,85 & 30,17 & 32 \\
P4 & 4,67 & 23,95 & 25 & 2,66 & 36,64 & 37 \\
P5 & 2,12 & 30,71 & 30 & 3,16 & 41,37 & 42 \\
P6 & 2,43 & 37,65 & 35 & 3,58 & 47,87 & 47 \\
P7 & 1,34 & 43,81 & 40 & 2,83 & 53,88 & 52 \\
P8 & 1,63 & 50,44 & 46 & 3,55 & 60,55 & 59 \\
P9 & 1,07 & 57,20 & 52 & 3,90 & 67,75 & 64 \\
P10 & 1,55 & 63,83 & 59 & 1,46 & 73,67 & 69 \\
P11 & 1,15 & 70,17 & 65 & 2,88 & 81,57 & 74 \\
P12 & 0,83 & 76,53 & 71 & 1,37 & 87,16 & 78 \\
P13 & 0,80 & 82,82 & 77 & 1,63 & 93,50 & 84 \\
P14 & 0,73 & 89,78 & 82 & & & \\
\hline P & & & & & & & \\
\end{tabular}

$P$ valor - 0.1000514

Média de tempo de duplicação: Enzimático= 24,18 hs, Explante= 23,7 hs

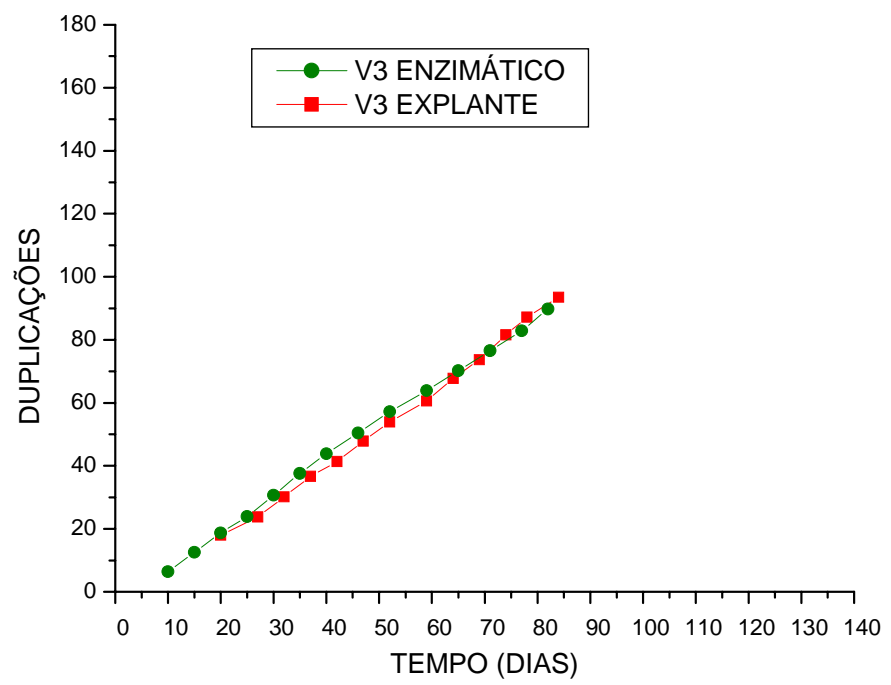

FIGURA 30- Número de duplicações de cada método ao longo dos dias: V3. 


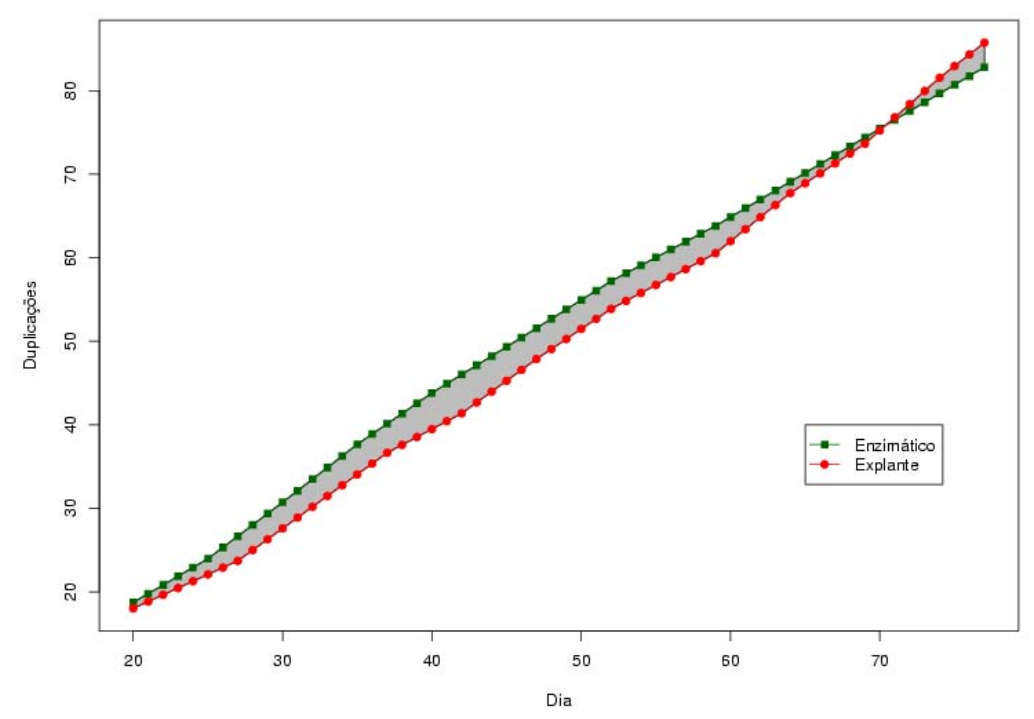

FIGURA 31- Comparações entre os dois métodos do número de duplicações celulares: V3.

TABELA 10- Quantidade de células obtidas em cada passagem, número de duplicações e dias transcorridos: Voluntário 5

\begin{tabular}{c|ccccccc}
\hline Passagens & \multicolumn{2}{|c}{ Enzimático } & Dias & \multicolumn{2}{c}{ Explante } & Dias \\
\cline { 2 - 3 } & $\begin{array}{c}\text { Quantidade } \\
\text { de cels. } \\
\left(\times 10^{6}\right)\end{array}$ & $\begin{array}{c}\text { Número de } \\
\text { duplicações }\end{array}$ & & $\begin{array}{c}\text { Quantidade } \\
\text { de cels. } \\
\left(\times 10^{6}\right)\end{array}$ & $\begin{array}{c}\text { Número de } \\
\text { duplicações }\end{array}$ & \\
P1 & 5,28 & 13 & & & 0,38 & 16 & 18 \\
P2 & 6,60 & 18,65 & 16 & 1,48 & 20,90 & 23 \\
P3 & 2,35 & 23,82 & 22 & 2,96 & 27,66 & 28 \\
P4 & 2,22 & 28 & 28 & 1,24 & 31,23 & 33 \\
P5 & 2,33 & 34 & 34 & 1,88 & 36,83 & 39 \\
P6 & 1,08 & 40,52 & 40 & 1,42 & 42,45 & 45 \\
P7 & 1,82 & 47,77 & 45 & 1,98 & 49,58 & 50 \\
P8 & 1,23 & 53,82 & 51 & 1,52 & 55,04 & 56 \\
P9 & 2,40 & 60,39 & 56 & 1,37 & 60,66 & 61 \\
P10 & 2,23 & 67,31 & 62 & 1,21 & 66,50 & 67 \\
P11 & 3,92 & 75,04 & 68 & 1,21 & 72,46 & 73 \\
P12 & 0,96 & 80,74 & 74 & 0,71 & 77,73 & 79 \\
P13 & 2,13 & 86,11 & 78 & 0,98 & 83,39 & 84 \\
P14 & 1,50 & 91 & 82 & 1,33 & 89,79 & 89 \\
P15 & 1,92 & 98,30 & 86 & 2,12 & 97,29 & 95 \\
P16 & 2,06 & 103,83 & 88 & 0,64 & 103,84 & 98 \\
P17 & 2,18 & 109,9 & 93 & 1,13 & 109,55 & 104 \\
P18 & 1,45 & 115,32 & 96 & 0,76 & 116,12 & 110 \\
P19 & 3,12 & 122,3 & 102 & & & \\
P20 & 1,56 & 127 & 106 & & & \\
\hline
\end{tabular}

\section{$P$ valor -0.001341897}

Média de tempo de duplicação: Enzimático= 21,57 hs, Explante= 24,38 hs. 


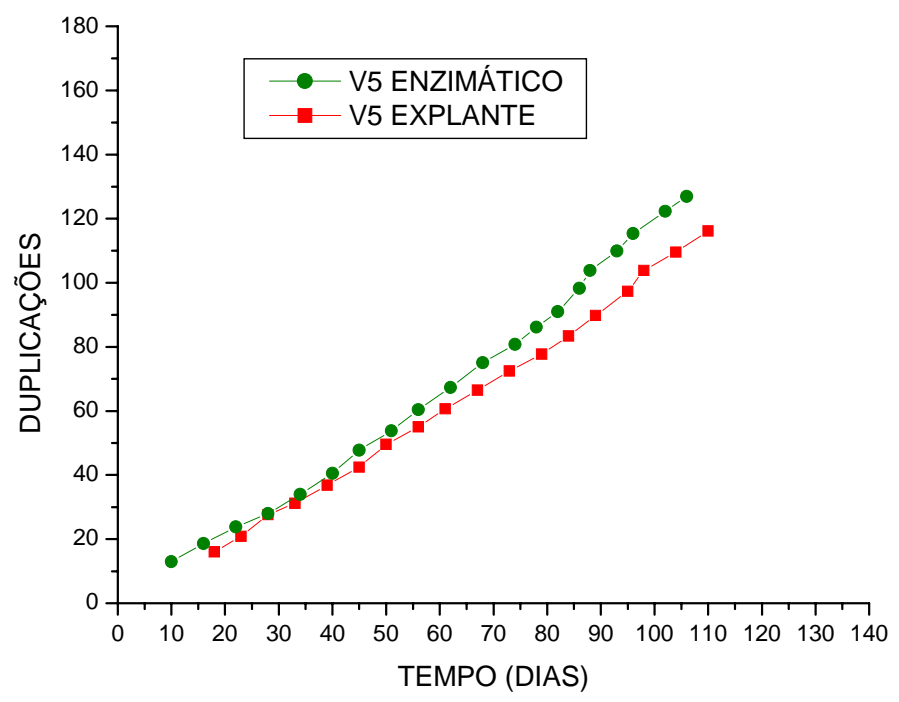

FIGURA 32- Número de duplicações de cada método ao longo dos dias: V5.

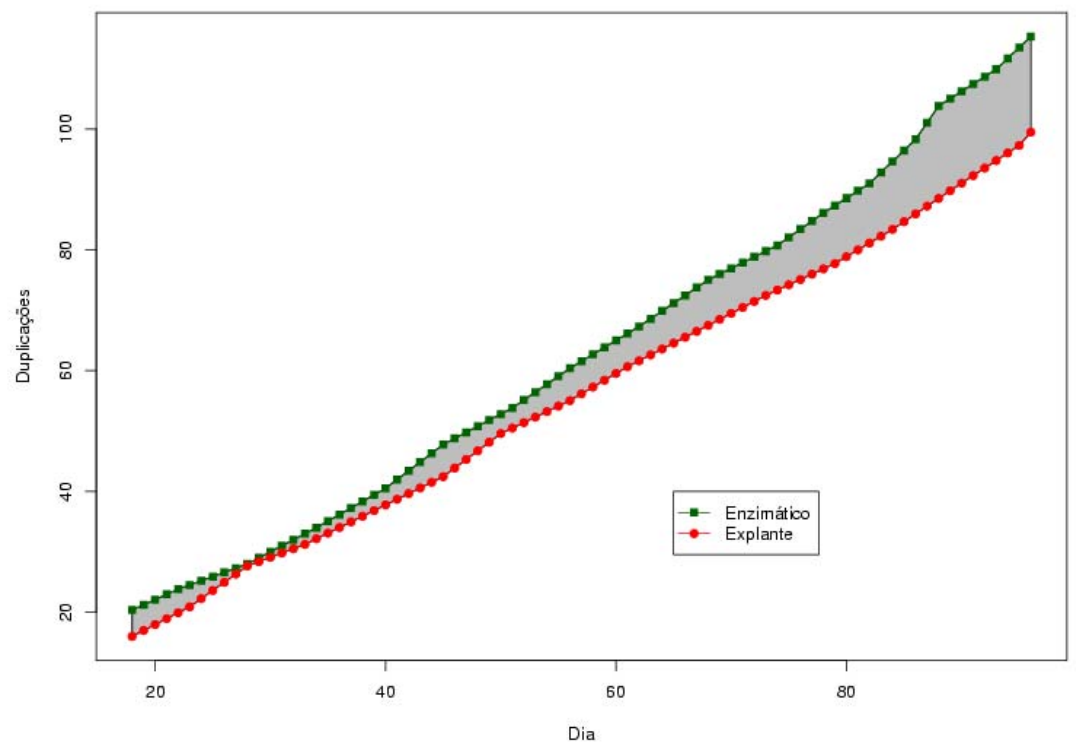

FIGURA 33- Comparação entre os dois métodos do número de duplicações: V5. 
TABELA 11- Quantidade de células obtidas em cada passagem, número de duplicações e dias transcorridos: Voluntário 6

\begin{tabular}{c|ccc}
\hline Passagens & \multicolumn{2}{|c}{ Enzimático } & Dias \\
\cline { 2 - 3 } & $\begin{array}{c}\text { Quantidade } \\
\text { de cels. } \\
\left(\times 10^{6}\right)\end{array}$ & $\begin{array}{c}\text { Número de } \\
\text { duplicações }\end{array}$ \\
P1 & 2,40 & 14,50 & 12 \\
P2 & 3,38 & 20,90 & 17 \\
P3 & 1,47 & 24,70 & 23 \\
P4 & 0,83 & 32,50 & 28 \\
P5 & 0,78 & 38,14 & 36 \\
P6 & 2,20 & 46 & 43 \\
P7 & 1,08 & 51,88 & 50 \\
P8 & 1,29 & 58,3 & 55 \\
P9 & 1 & 64 & 62 \\
P10 & 1,49 & 71,42 & 68 \\
P11 & 0,99 & 78,27 & 74 \\
\hline
\end{tabular}

Média de tempo de duplicação: Enzimático $=22$ hs.

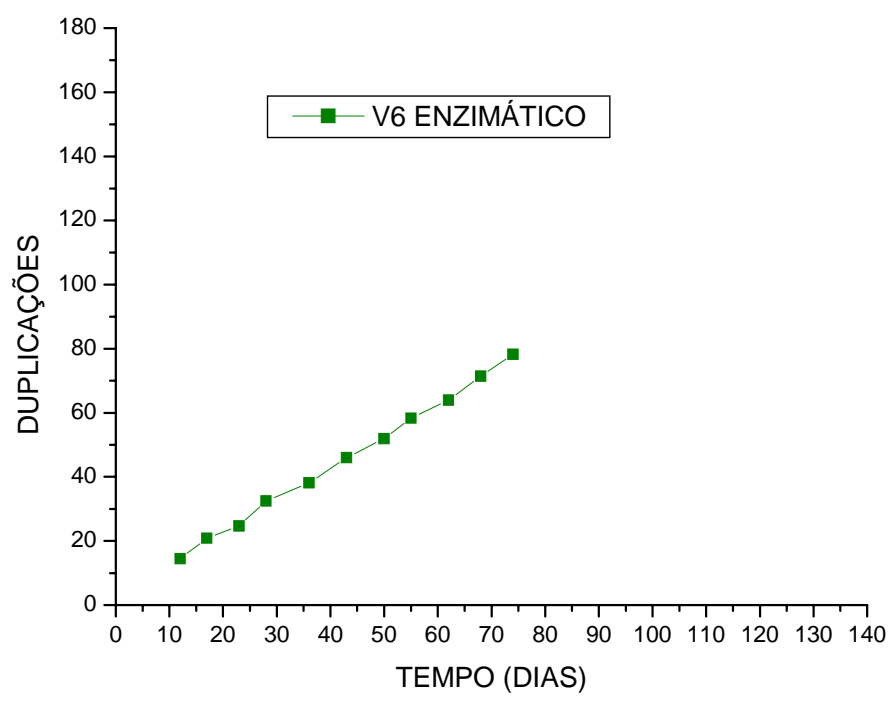

FIGURA 34- Número de duplicações do método enzimático ao longo dos dias: V6. 
TABELA 12- Quantidade de células obtidas em cada passagem, número de duplicações e dias transcorridos: Voluntário 8

\begin{tabular}{c|ccccccc}
\hline Passagens & \multicolumn{2}{|c}{ Enzimático } & Dias & \multicolumn{2}{c}{ Explante } & Dias \\
\cline { 2 - 3 } & $\begin{array}{c}\text { Quantidade } \\
\text { de cels. } \\
\left(\times 10^{6}\right)\end{array}$ & $\begin{array}{c}\text { Número de } \\
\text { duplicações }\end{array}$ & & $\begin{array}{c}\text { Quantid. de } \\
\text { cels. } \\
\left(\times 10^{6}\right)\end{array}$ & $\begin{array}{c}\text { Número de } \\
\text { duplicações }\end{array}$ & \\
P1 & 0,34 & 3 & 6 & 0,07 & 16 & 16 \\
P2 & 5 & 9,22 & 11 & 0,34 & 18,29 & 26 \\
P3 & 2,83 & 17,11 & 16 & 2,80 & 24,02 & 32 \\
P4 & 1,98 & 23,52 & 21 & 1,32 & 29,28 & 38 \\
P5 & 1,23 & 33,21 & 28 & 1,78 & 35,41 & 43 \\
P6 & 0,63 & 38,97 & 34 & 0,60 & 42,06 & 59 \\
P7 & 1,58 & 45,23 & 42 & 0,42 & 48,74 & 64 \\
P8 & 1,71 & 52,03 & 48 & & & \\
P9 & 1,17 & 58,12 & 54 & & & & \\
\hline
\end{tabular}

$P$ valor -0.0006460338

Média de tempo de duplicação: Enzimático= 25,06 hs, Explante= 31,92 hs

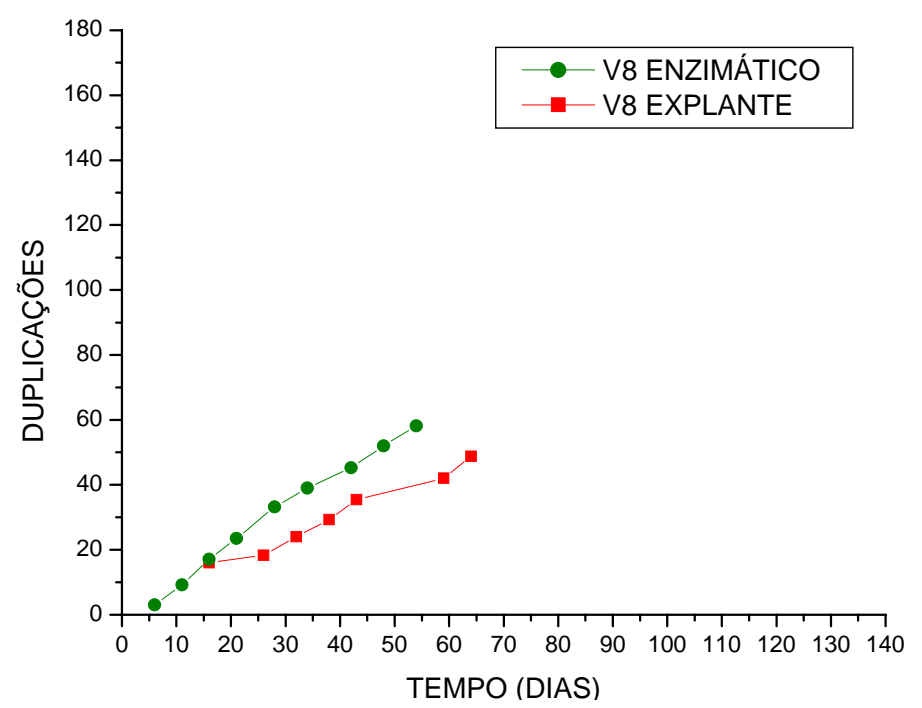

FIGURA 35- Número de duplicações de cada método ao longo dos dias: V8.

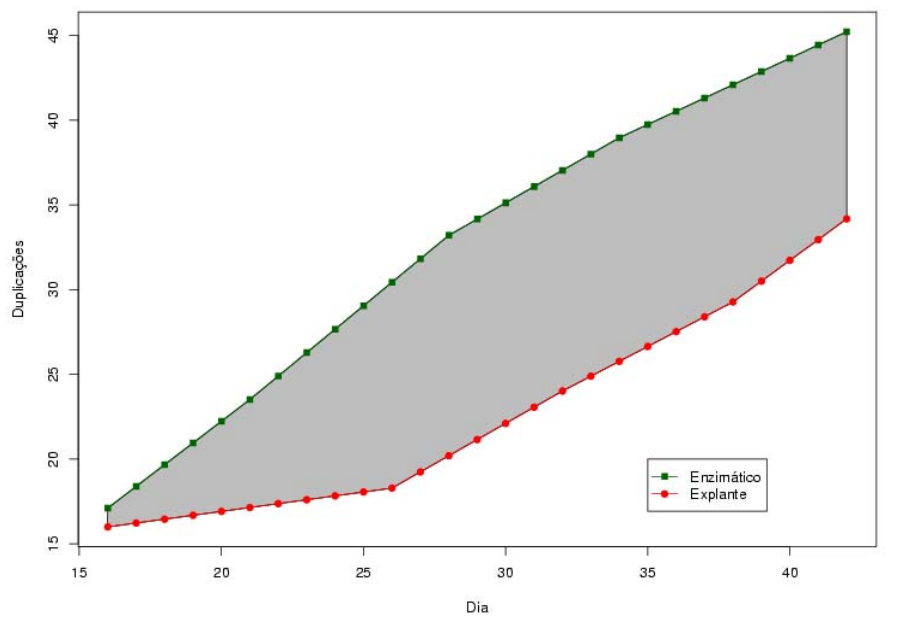

FIGURA 36- Número de duplicações de cada método ao longo dos dias: V8. 
TABELA 13- Quantidade de células obtidas em cada passagem, número de duplicações e dias transcorridos: Voluntário 9

\begin{tabular}{c|ccc}
\hline Passagens & \multicolumn{2}{|c}{ Enzimático } & Dias \\
\cline { 2 - 3 } & $\begin{array}{c}\text { Quantidade } \\
\text { de cels. } \\
\text { (x 106) }\end{array}$ & $\begin{array}{c}\text { Número de } \\
\text { duplicações }\end{array}$ \\
P1 & 1,89 & 15,34 & 11 \\
P2 & 4,15 & 24,83 & 16 \\
P3 & 4,57 & 30,22 & 20 \\
P4 & 2,70 & 38,24 & 25 \\
P5 & 1,47 & 44,66 & 30 \\
P6 & 2 & 53,13 & 35 \\
P7 & 0,77 & 59,68 & 42 \\
P8 & 0,97 & 64,77 & 47 \\
P9 & 1,89 & 71,40 & 53 \\
P10 & 1 & 77,23 & 60 \\
P11 & 0,48 & 82,14 & 67 \\
\hline
\end{tabular}

Média de duplicação: Enzimático $=16,95$ hs

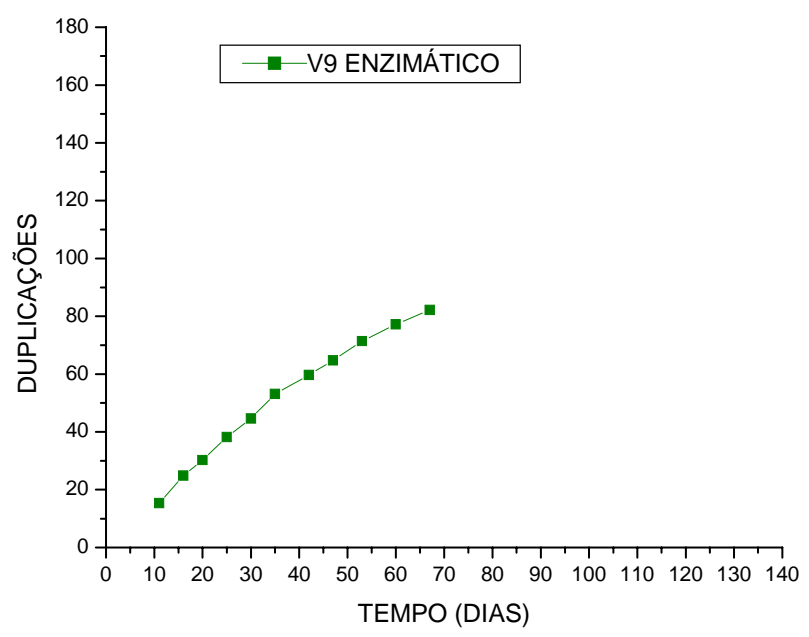

FIGURA 37- Número de duplicações do método enzimático ao longo dos dias: V9. 
TABELA 14- Quantidade de células obtidas em cada passagem, número de duplicações e dias transcorridos: Voluntário 10

\begin{tabular}{|c|c|c|c|c|c|c|}
\hline \multirow[t]{2}{*}{ Passagens } & \multicolumn{2}{|c|}{ Enzimático } & \multirow[t]{2}{*}{ Dias } & \multicolumn{2}{|c|}{ Explante } & \multirow[t]{2}{*}{ Dias } \\
\hline & $\begin{array}{l}\text { Quantidade } \\
\text { de cels. } \\
\left(\times 10^{6}\right)\end{array}$ & $\begin{array}{l}\text { Número de } \\
\text { duplicações }\end{array}$ & & $\begin{array}{l}\text { Quantidade } \\
\text { de cels. } \\
\left(\times 10^{6}\right)\end{array}$ & $\begin{array}{l}\text { Número de } \\
\text { duplicações }\end{array}$ & \\
\hline P1 & 1,57 & 12,56 & 14 & 0,12 & 17 & 17 \\
\hline P2 & 4,11 & 19,28 & 19 & 4,46 & 23,73 & 23 \\
\hline P3 & 2,10 & 25,66 & 25 & 3,27 & 28,36 & 27 \\
\hline P4 & 1,61 & 32,33 & 31 & 1,67 & 33,70 & 33 \\
\hline P5 & 0,77 & 40,81 & 36 & 1,12 & 40,08 & 39 \\
\hline P6 & 0,93 & 49,61 & 42 & 1 & 47,35 & 45 \\
\hline
\end{tabular}

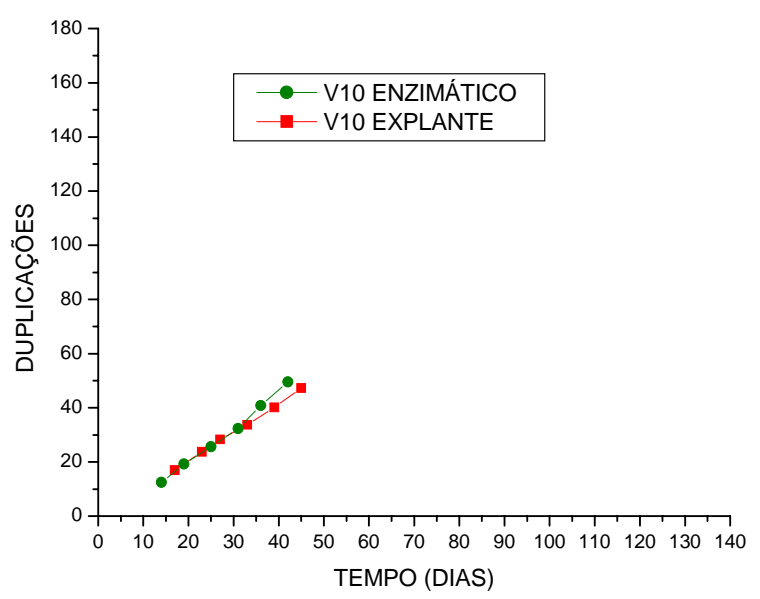

FIGURA 38- Número de duplicações de cada método ao longo dos dias: V10.

TABELA 15- Quantidade de células obtidas em cada passagem, número de duplicações e dias transcorridos: Voluntário 13

\begin{tabular}{|c|c|c|c|c|c|c|}
\hline \multirow[t]{2}{*}{ Passagens } & \multicolumn{2}{|c|}{ Enzimático } & \multirow[t]{2}{*}{ Dias } & \multicolumn{2}{|c|}{ Explante } & Dias \\
\hline & $\begin{array}{l}\text { Quantidade } \\
\text { de cels. } \\
\left(\times 10^{6}\right)\end{array}$ & $\begin{array}{l}\text { Número de } \\
\text { duplicações }\end{array}$ & & $\begin{array}{l}\text { Quantidade } \\
\text { de cels. } \\
\left(\times 10^{6}\right)\end{array}$ & $\begin{array}{l}\text { Número de } \\
\text { duplicações }\end{array}$ & \\
\hline P1 & 1 & 4,31 & 10 & 0,54 & 15 & 15 \\
\hline P2 & 2,92 & 8,93 & 14 & 2,73 & 19,87 & 21 \\
\hline P3 & 1,50 & 11,5 & 20 & 0,27 & 21,47 & 28 \\
\hline
\end{tabular}

Média de tempo de duplicação: Enzimático $=44,98 \mathrm{hs}$, Explante $=26,88 \mathrm{hs}$ 


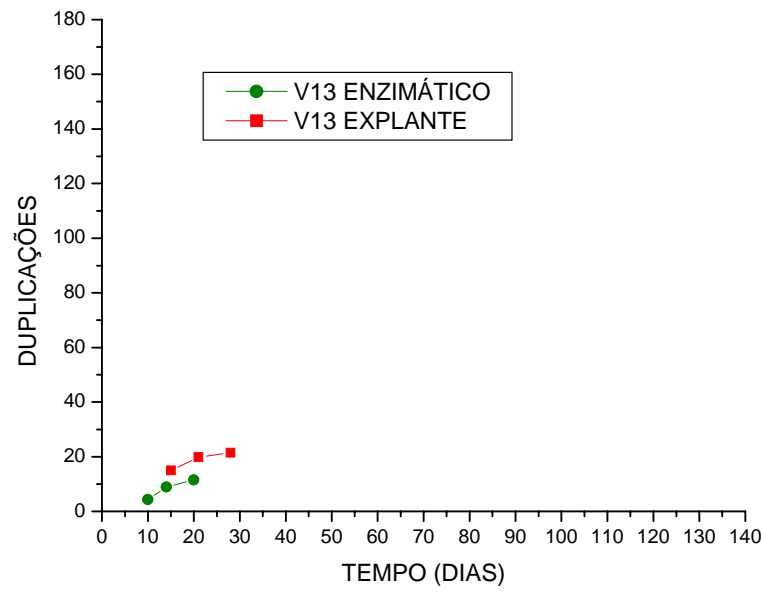

FIGURA 39- Número de duplicações de cada método ao longo dos dias: V13.

TABELA 16- Quantidade de células obtidas em cada passagem, número de duplicações e dias transcorridos: Voluntário 15

\begin{tabular}{|c|c|c|c|c|c|c|}
\hline \multirow[t]{2}{*}{ Passagens } & \multicolumn{2}{|c|}{ Enzimático } & \multirow[t]{2}{*}{ Dias } & \multicolumn{2}{|c|}{ Explante } & \multirow[t]{2}{*}{ Dias } \\
\hline & $\begin{array}{l}\text { Quantidade } \\
\text { de cels. } \\
\left(\times 10^{6}\right)\end{array}$ & $\begin{array}{l}\text { Número de } \\
\text { duplicações }\end{array}$ & & $\begin{array}{c}\text { Quantidade } \\
\text { de cels. } \\
\left(\times 10^{6}\right)\end{array}$ & $\begin{array}{l}\text { Número de } \\
\text { duplicações }\end{array}$ & \\
\hline P1 & 5,15 & 16,65 & 11 & 0,08 & 13 & 14 \\
\hline P2 & 3,27 & 22,01 & 16 & 0,65 & 19,56 & 21 \\
\hline P3 & 1,73 & 25,75 & 22 & 2,63 & 24,31 & 26 \\
\hline P4 & 1,70 & 29,70 & 28 & 1,12 & 28 & 32 \\
\hline & & & & 1,24 & 31,99 & 35 \\
\hline
\end{tabular}

Média de tempo de duplicação: Enzimático= 19,1hs, Explante= 26,01h.

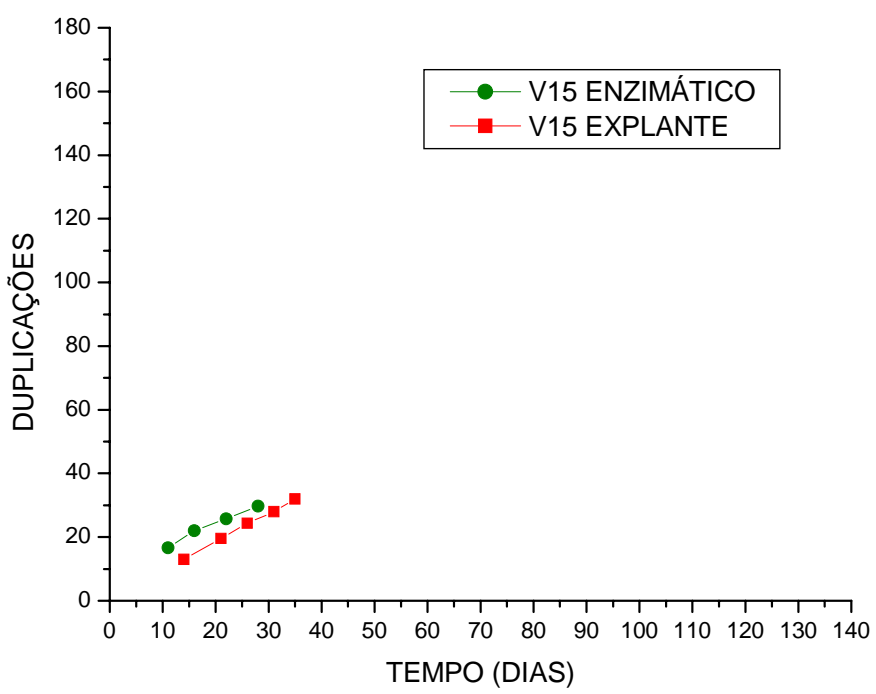

FIGURA- 40 Número de duplicações de cada método ao longo dos dias: V15. 
TABELA 17- Quantidade de células obtidas em cada passagem, número de duplicações e dias transcorridos: Voluntário 16

\begin{tabular}{c|ccccccc}
\hline Passagens & \multicolumn{2}{|c}{ Enzimático } & Dias & \multicolumn{2}{c}{ Explante } & Dias \\
\cline { 2 - 3 } & $\begin{array}{c}\text { Quantidade } \\
\text { de cels. } \\
\left(\times 10^{6}\right)\end{array}$ & $\begin{array}{c}\text { Número de } \\
\text { duplicações }\end{array}$ & & $\begin{array}{c}\text { Quantidade } \\
\text { de cels. } \\
\left(\times 10^{6}\right)\end{array}$ & $\begin{array}{c}\text { Número de } \\
\text { duplicações }\end{array}$ & \\
P1 & 5,31 & 6,70 & & & 0,15 & 14 & 14 \\
P2 & 2,27 & 12,01 & 18 & 2,28 & 29,15 & 18 \\
P3 & 2,54 & 18,70 & 23 & 3 & 44,64 & 23 \\
P4 & 0,89 & 21,01 & 30 & 2,55 & 60,01 & 26 \\
\hline
\end{tabular}

Média de tempo de duplicação: Enzimático= 34,64 hs, Explante= 15,39 hs

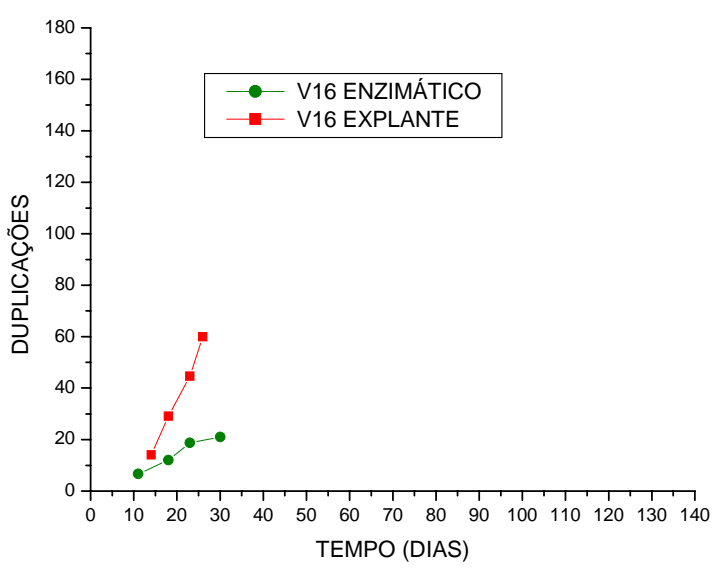

FIGURA 41- Número de duplicações de cada método ao longo dos dias: V16.

TABELA 18- Quantidade de células obtidas em cada passagem, número de duplicações e dias transcorridos: Voluntário 32

\begin{tabular}{c|ccccccc}
\hline Passagens & \multicolumn{2}{|c}{ Enzimático } & Dias & \multicolumn{2}{c}{ Explante } & Dias \\
\cline { 2 - 3 } & $\begin{array}{c}\text { Quantidade } \\
\text { de cels. } \\
\left(\times 10^{6}\right)\end{array}$ & $\begin{array}{c}\text { Número de } \\
\text { duplicações }\end{array}$ & & $\begin{array}{c}\text { Quantidade } \\
\text { de cels. } \\
\left(\times 10^{6}\right)\end{array}$ & $\begin{array}{c}\text { Número de } \\
\text { duplicações }\end{array}$ & \\
P1 & 0,42 & 1,20 & 9 & & 0,03 & 11 & 11 \\
P2 & 0,70 & 3,67 & 15 & 0,34 & 14,29 & 24 \\
P3 & 1,87 & 8,36 & 21 & & 0,72 & 20,12 & 27 \\
P4 & 2,40 & 13,54 & 27 & & 0,40 & 25,32 & 34 \\
P5 & 1,33 & 18,45 & 34 & & \\
\hline
\end{tabular}

Média de tempo de duplicação: Enzimático $=57,34$ hs, Explante $=32,18$ hs 


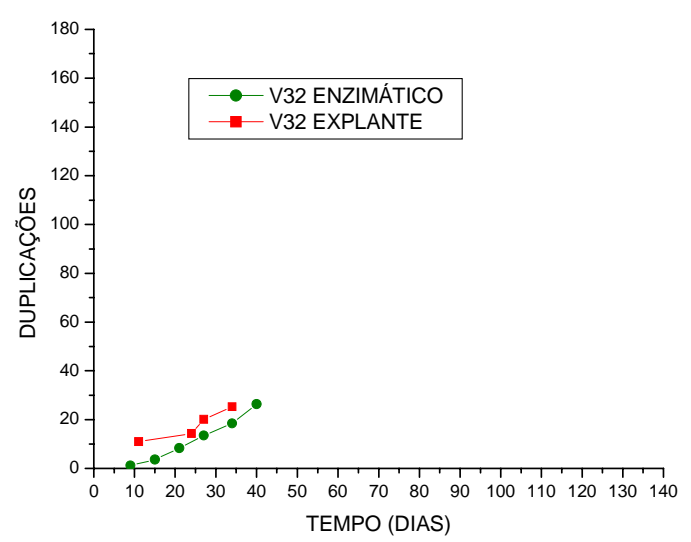

FIGURA 42- Número de duplicações de cada método ao longo dos dias: V32.

TABELA 19- Quantidade de células obtidas em cada passagem, número de duplicações e dias transcorridos: Voluntário 33

\begin{tabular}{|c|c|c|c|c|c|c|}
\hline \multirow[t]{2}{*}{ Passagens } & \multicolumn{2}{|c|}{ Enzimático } & Dias & \multicolumn{2}{|c|}{ Explante } & Dias \\
\hline & $\begin{array}{l}\text { Quantidade } \\
\text { de cels. } \\
\left(\times 10^{6}\right)\end{array}$ & $\begin{array}{l}\text { Número de } \\
\text { duplicações }\end{array}$ & & $\begin{array}{l}\text { Quantidade } \\
\text { de cels. } \\
\left(\times 10^{6}\right)\end{array}$ & $\begin{array}{l}\text { Número de } \\
\text { duplicações }\end{array}$ & \\
\hline P1 & 0,01 & 10 & 11 & 0,20 & 21 & 21 \\
\hline P2 & 0,68 & 15,78 & 24 & 1,65 & 24,66 & 26 \\
\hline P3 & & & & 3,32 & 32,68 & 32 \\
\hline P4 & & & & 1,65 & 39,46 & 38 \\
\hline
\end{tabular}

Média de tempo de duplicação: Enzimático= 63,01 hs, Explante $=18,65$ hs

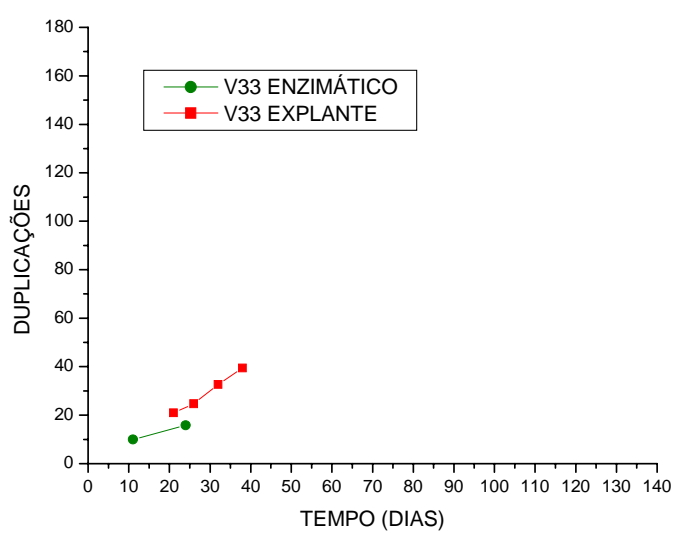

FIGURA 43- Número de duplicações de cada método ao longo dos dias: V33. 
TABELA 20- Quantidade de células obtidas em cada passagem, número de duplicações e dias transcorridos: Voluntário 34

\begin{tabular}{c|ccccccc}
\hline Passagens & \multicolumn{2}{|c}{ Enzimático } & Dias & \multicolumn{2}{c}{ Explante } & Dias \\
\cline { 2 - 3 } & $\begin{array}{c}\text { Quantidade } \\
\text { de cels. } \\
\text { (x 106) }\end{array}$ & $\begin{array}{c}\text { Número de } \\
\text { duplicações }\end{array}$ & & $\begin{array}{c}\text { Quantidade } \\
\text { de cels. } \\
\left(\times 10^{6}\right)\end{array}$ & $\begin{array}{c}\text { Número de } \\
\text { duplicações }\end{array}$ & \\
P1 & 2,31 & 6,70 & 18 & 0,01 & 9 & 9 \\
P2 & 3,49 & 11,57 & 22 & 0,57 & 14,84 & 19 \\
P3 & 1,95 & 17,50 & 27 & & & \\
P4 & 2,12 & 22,50 & 33 & & & \\
P5 & 1,83 & 28,67 & 39 & & & & \\
\hline
\end{tabular}

Média de tempo de duplicação Enzimático= 42,9 hs, Explante $=27,36$ hs

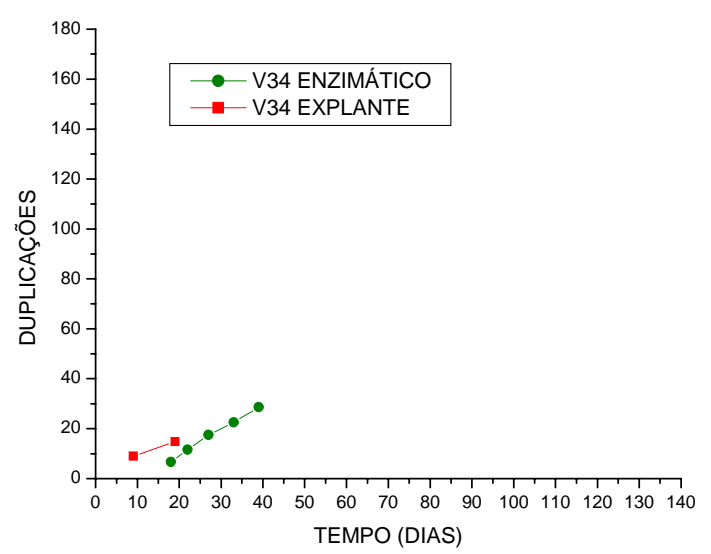

FIGURA 44- Número de duplicações de cada método ao longo dos dias: V34.

\subsection{Tempo de vida celular resultante de cultivo realizado em alta densidade.}

\subsubsection{Cultivo de queratinócitos em alta densidade com meio K+.}

Para esse teste foram cultivados queratinócitos provenientes dos dois métodos avaliados, de um mesmo voluntário, na mesma passagem ( $P$ 2), e o meio utilizado foi $\mathrm{K}+$. A seguir na TAB. 21 são apresentadas as quantidades de células obtidas na sub-confluência de cada passagem e o respectivo número de duplicações necessários para atingir este estágio. O número de duplicações foi obtido por meio da Equação 1 (vide 4.5) utilizando os dados de: quantidade de células, dias transcorridos, e totais de colônias obtidas por meio do teste de EFC contidos no APÊNDICE C. A seguir na FIG. 45 são mostrados os números de duplicações e tempo transcorridos, referentes à tabela. 
TABELA 21- Quantidade de células obtidas em cada passagem, número de duplicações e dias transcorridos.

\begin{tabular}{c|ccccccc}
\hline Passagens & \multicolumn{2}{|c}{ Enzimático } & Dias & \multicolumn{2}{c}{ Explante } & Dias \\
\cline { 2 - 3 } $\begin{array}{c}\text { Quantidade. } \\
\text { de cels. } \\
\left(\times 10^{6}\right)\end{array}$ & $\begin{array}{c}\text { Número de } \\
\text { duplicações }\end{array}$ & & $\begin{array}{c}\text { Quantidade } \\
\text { de cels. } \\
\left(\times 10^{6}\right)\end{array}$ & $\begin{array}{c}\text { Número de } \\
\text { duplicações }\end{array}$ & \\
P2 & 1,38 & 1,62 & 3 & 0,79 & 0,82 & 3 \\
P3 & 0,45 & 3,52 & 5 & 0,51 & 3,70 & 5 \\
P4 & 0,29 & 9,53 & 7 & 0,23 & 5,06 & 7 \\
P5 & 0,26 & 16,02 & 10 & 0,22 & 8,75 & 11 \\
P6 & 0,14 & 18,91 & 16 & 0,08 & 11,76 & 24 \\
P7 & 0,11 & 25,36 & 19 & & & \\
P8 & 0,03 & 30,25 & 24 & & & & \\
\hline
\end{tabular}

Média de tempo de duplicação Enzimático= 24,04 hs, Explante= 36,16 hs

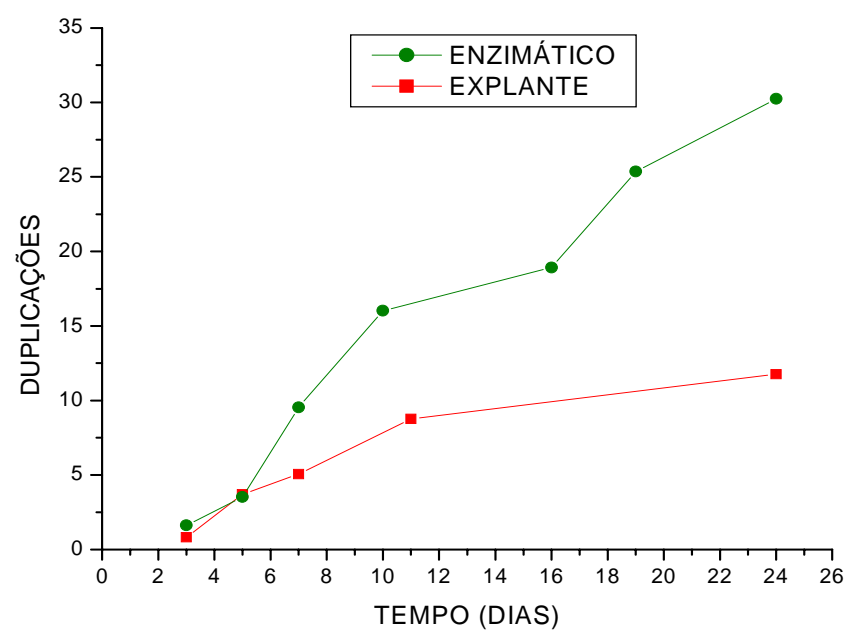

FIGURA 45- Número de duplicações de cada método ao longo dos dias.

A seguir na FIG. 46 são mostradas as imagens fotográficas dos aspectos morfológicos dos diferentes estágios das culturas em alta densidade de ambos os métodos.
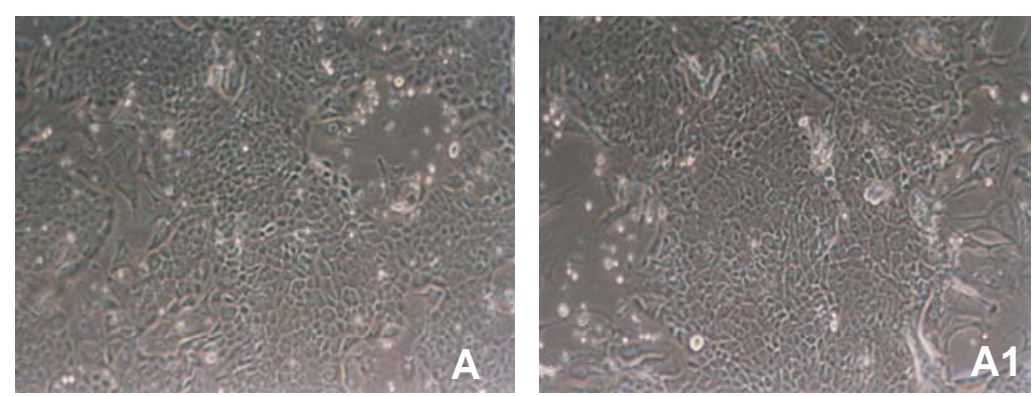

A- P2, dois dias de cultivo

A1- P2, dois dias de cultivo 

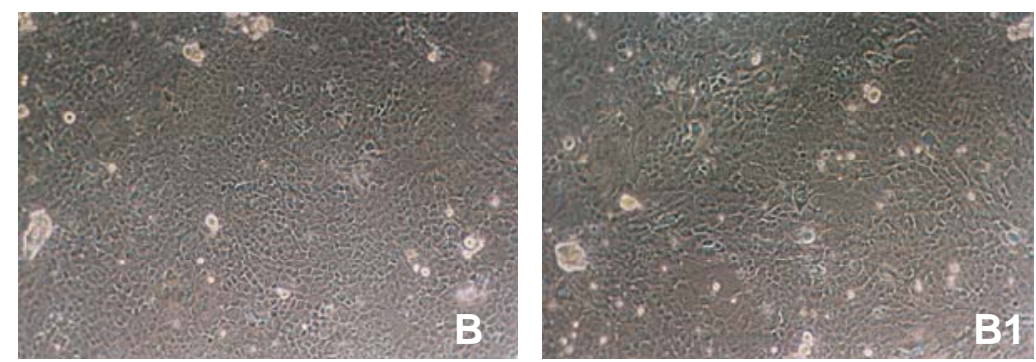

B- P2, sub-confluência, dia da tripsinização

B1- P2, sub-confluência, dia da tripsinização
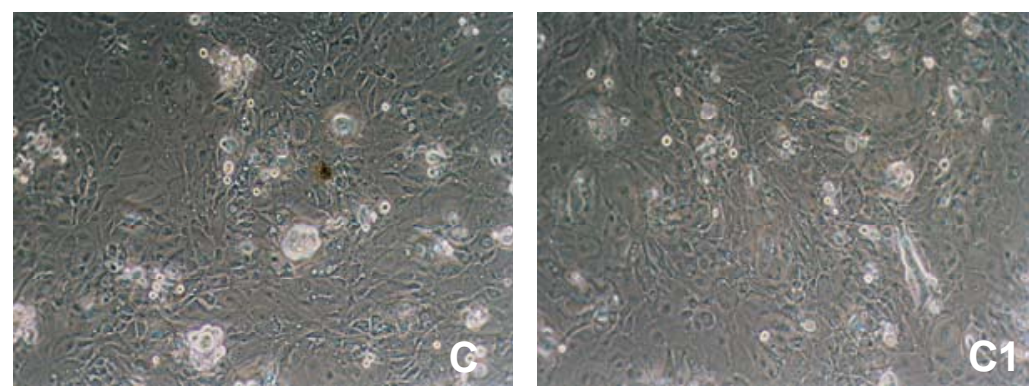

C- P4 dois dias de cultivo
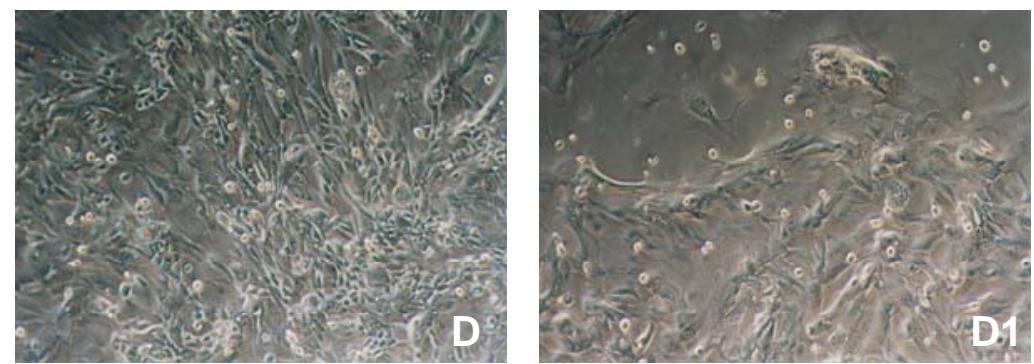

D- P5, sub-confluência, dia da tripsinização;

D1- P5, sub-confluência não atingida após três dias de cultivo
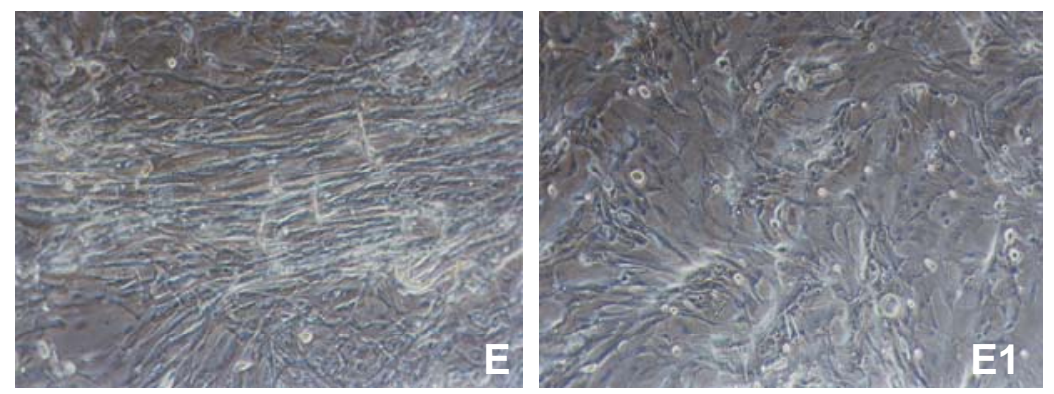

E- P6, seis dias de cultivo

E-1 P5, sub-confluência, dia da tripsinização após quatro dias de cultivo
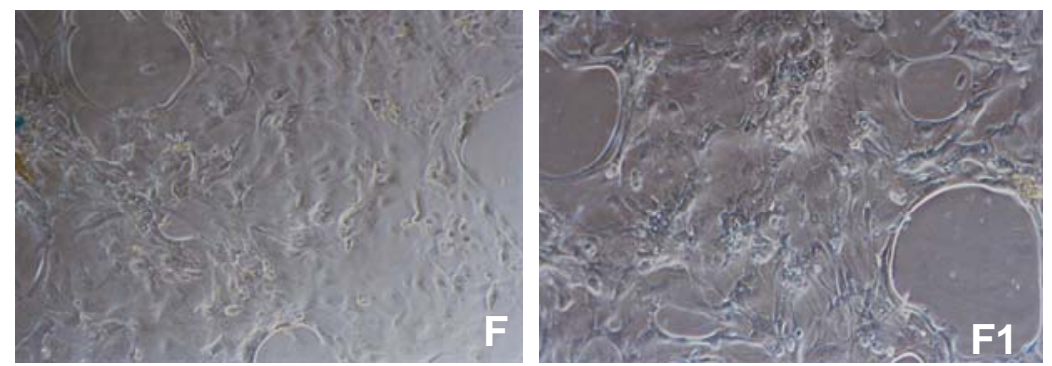

F- final da $P 9$, confluência não atingida após dez dias de cultivo

F1- final da P7, subconfluência não atingida após dez dias de cultivo

FIGURA 46- Imagens de algumas passagens das células cultivadas em alta densidade, método enzimático $\mathbf{A}, \mathbf{B}, \mathbf{C}, \mathbf{D}, \mathbf{E}, \mathbf{F}$ e método explante $\mathbf{A} \mathbf{1}, \mathbf{B} \mathbf{1}, \mathbf{C} \mathbf{1}$, D1, E1 e F1. Aumento de 100 vezes, com filtro azul. 


\subsubsection{Cultivo de queratinócitos em alta densidade com meio K-SFM}

Para esse teste foram cultivados queratinócitos provenientes dos dois métodos avaliados. As células foram provenientes de um mesmo voluntário, na mesma passagem (P 2) e o meio utilizado desta vez foi K-SFM.

A seguir na FIG. 47 são mostradas as imagens fotográficas dos aspectos morfológicos dos diferentes estágios das culturas em alta densidade com meio de cultura K-SFM de ambos os métodos.
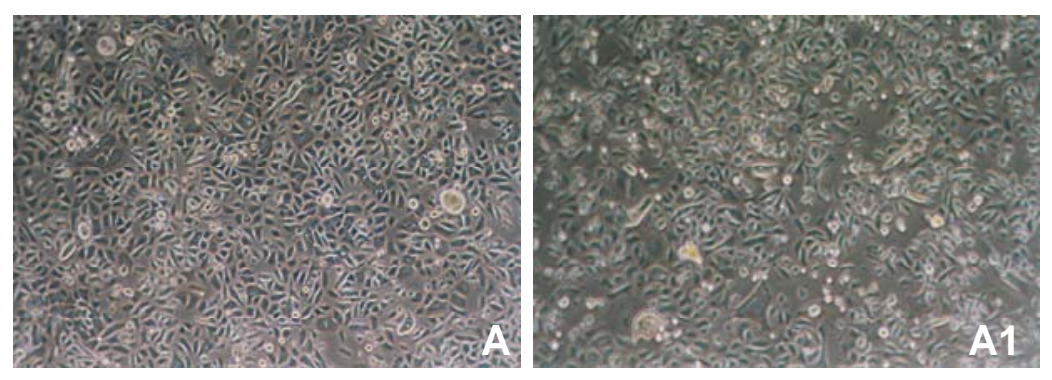

A- P2 dois dias de cultivo, método enzimático;

A1- P2 dois dias de cultivo, método explante
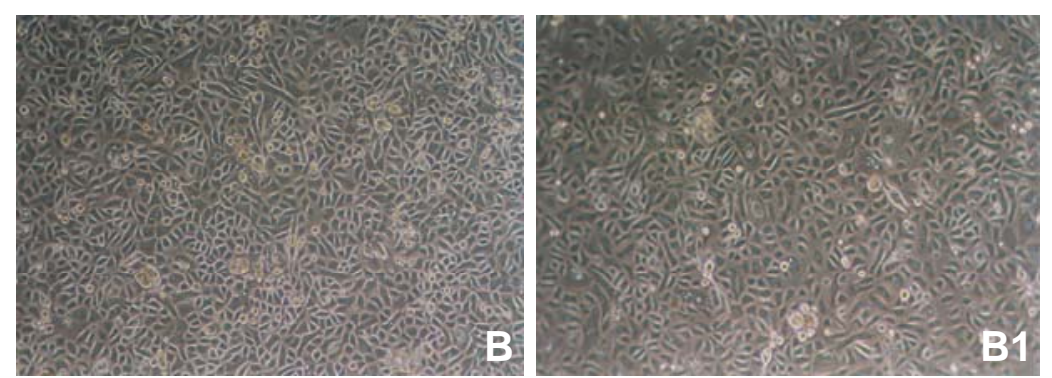

B- P2, sub-confluência, dia da tripsinização

B1- P2 sub-confluência, dia da tripsinização
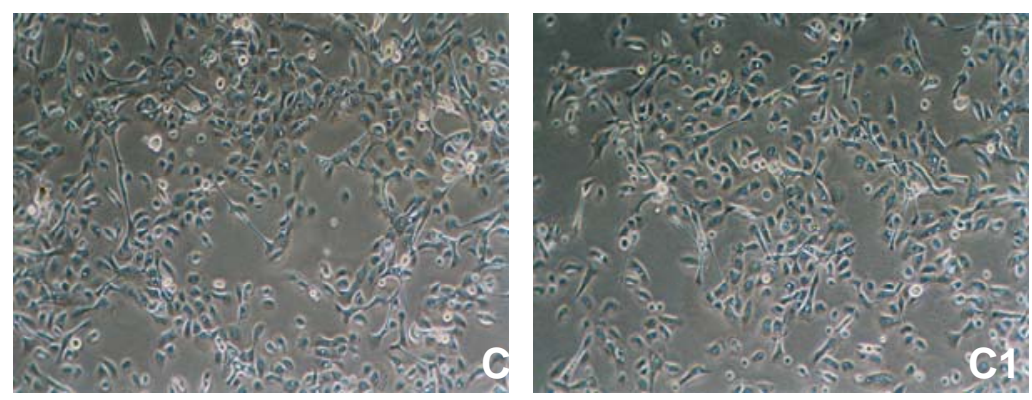

C- P3, dois dias de cultivo

C-1 P3, dois dias de cultivo
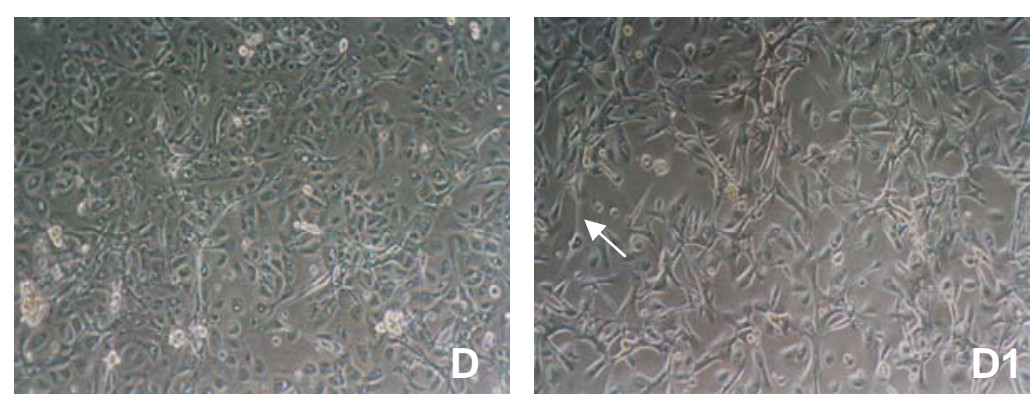

D- P3 sub-confluência, dia da tripsinização após cinco dias de cultivo

D1- P3, sete dias de cultivo, aparecimento de melanócitos ( 
$\mathbf{E}$

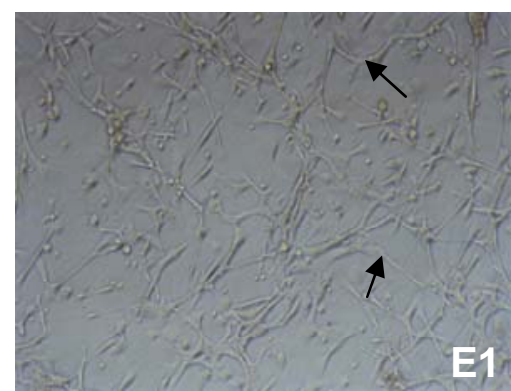

E- não houve adesão celular à placa

E1- P3, onze dias de cultivo, presença de melanócitos ( $)$

FIGURA 47- Imagens de algumas passagens das células cultivadas em alta densidade com meio K-SFM, método enzimático $\mathbf{A}, \mathbf{B}, \mathbf{C}, \mathbf{D}, \mathbf{E}$, e método explante A1, B1, C1, D1, e E1. Aumento de 100 vezes, com filtro azul.

\subsection{Confecção dos epitélios}

Os epitélios foram confeccionados com células provenientes dos dois métodos de obtenção celular: enzimático e explante (vide 4.6). Após vários dias de confluência foram retirados da placa de cultivo por meio da ação da enzima dispase e conservados em solução de formaldeído a 10\%.

$\mathrm{Na}$ FIG. 48, 49 e 50, imagens fotográficas da aparência dos queratinócitos em cultura após a confluência.
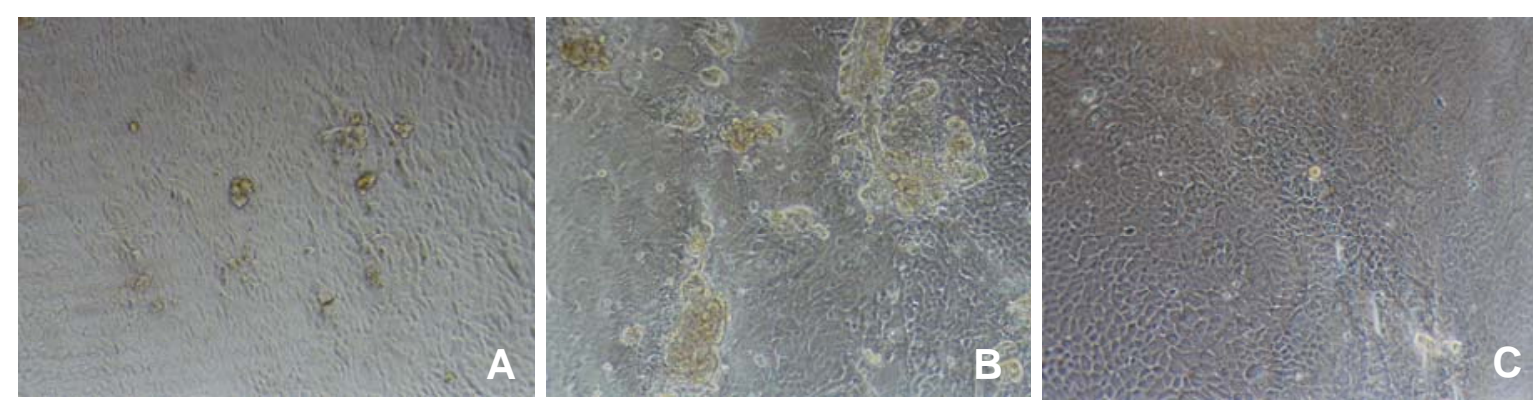

FIGURA 48- Aparência dos queratinócitos cultivados: A) no dia que atingiram a confluência, semeados em alta densidade; B) no mesmo dia em que os queratinócitos semeados em alta densidade atingiram a confluência, estes ainda não atingiram o mesmo estágio, semeados sobre a camada de sustentação; C) dois dias após as imagens anteriores, dia em que estes queratinócitos, semeados sobre a camada de sustentação atingiram a confluência. (Explante) Aumento 100 vezes, com filtro azul.
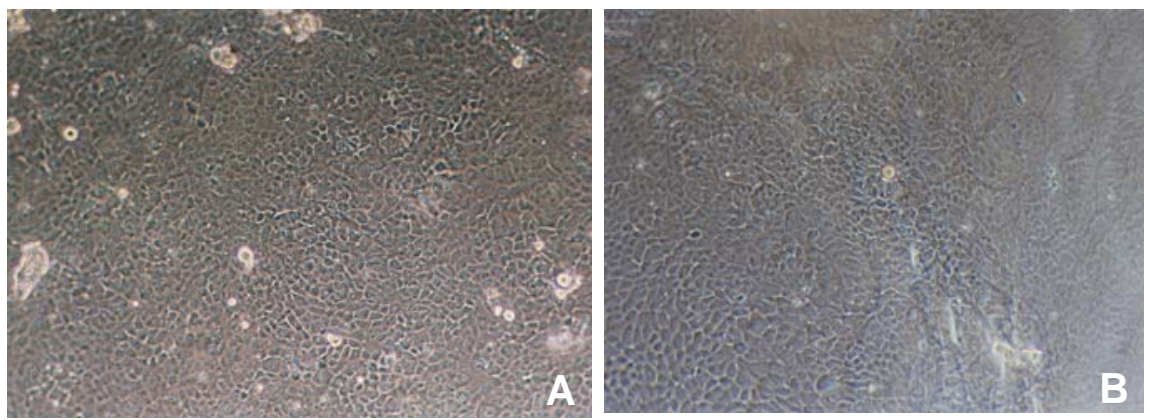

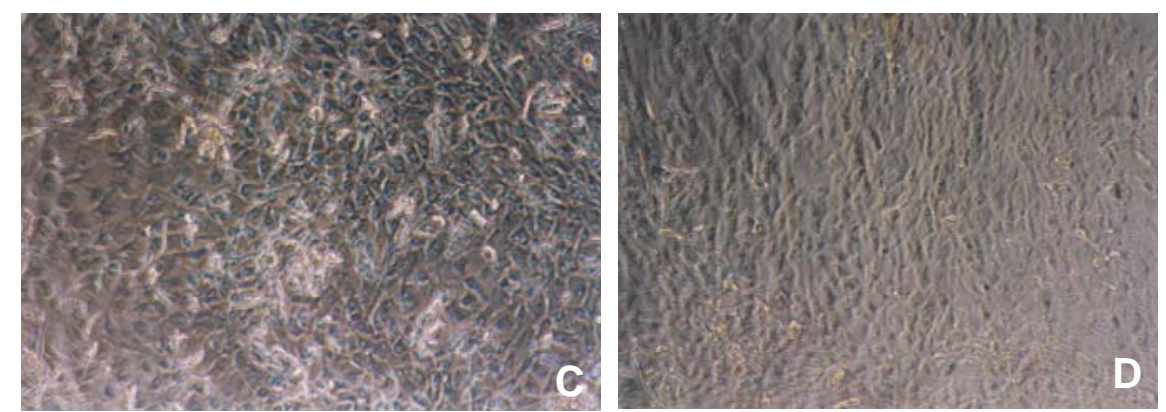

FIGURA 49- Aparência dos queratinócitos cultivados: A) Um dia de confluência, método enzimático; B) Um dia de confluência, método explante; C) 18 dias de confluência, método enzimático; D) 18 dias de confluência, método explante. Aumento de 100 vezes, com filtro azul.
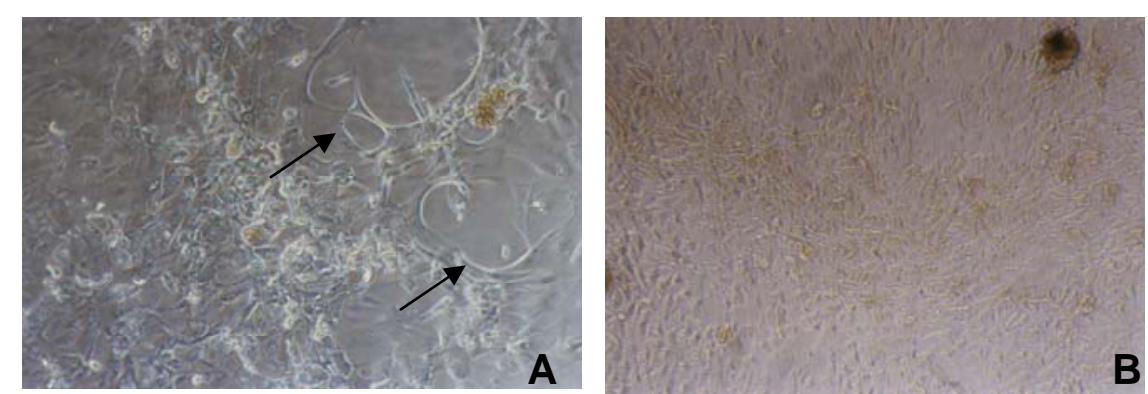

FIGURA 50- Aparência dos queratinócitos cultivados: A) no $28^{\circ}$ dia de confluência, (J) orifício na camada celular formada, provocada pelo processo de descamação, método enzimático; B) no $28^{\circ}$ dia de confluência, método explante. Aumento de 100 vezes, com filtro azul.

A seguir, na FIG. 51 imagens dos epitélios formados, no momento que foram removidos das placas de cultivo e na FIG. 52 e 53 após a conservação em solução de formaldeído a $10 \%$.
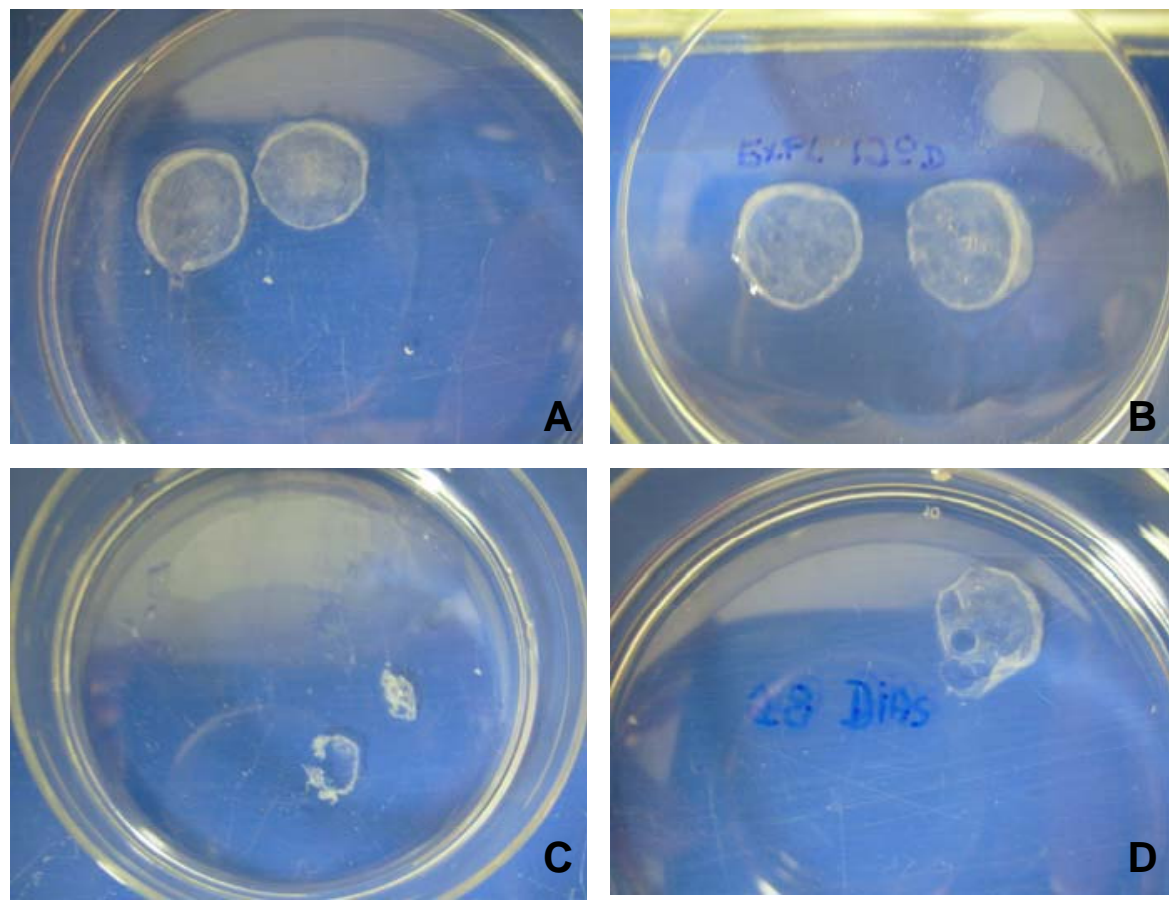
FIGURA 51- Epitélio formado com queratinócitos cultivados, no momento que foram retirados dos poços de cultivo por meio da ação da enzima dispase: A) após 12 dias de confluência, método enzimático; B) após 12 dias e confluência método explante; $\mathbf{C}$ ) após 28 dias de confluência, método enzimático; D) após 28 dias de confluência, método explante.
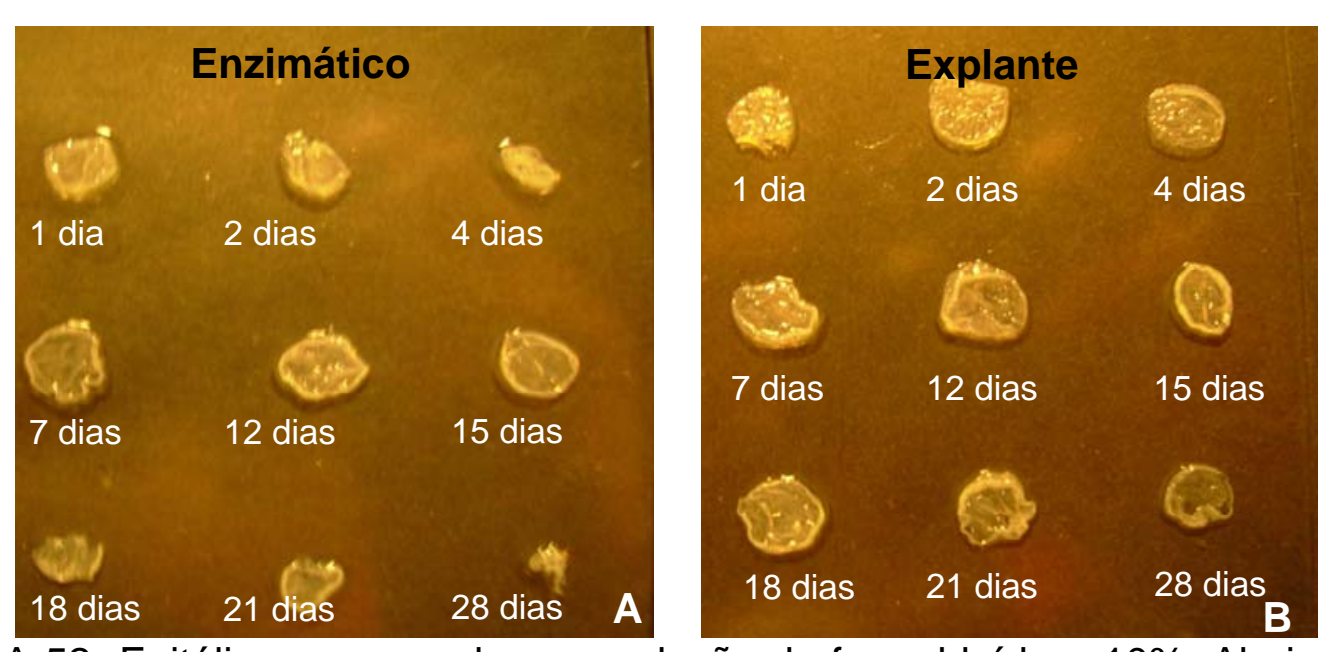

FIGURA 52- Epitélios conservados em solução de formaldeído a 10\%. Abaixo de cada epitélio, quantidade de dias após a confluência: A) Método enzimático e B) Método explante.

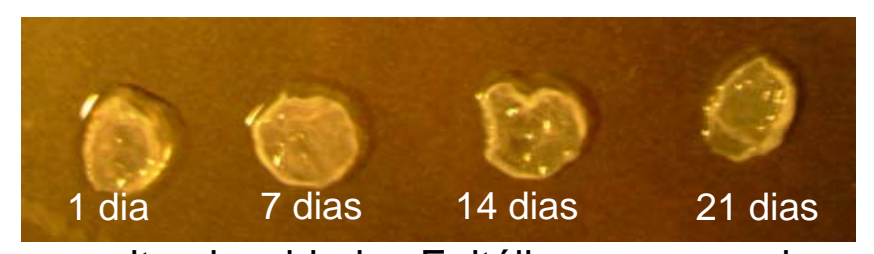

FIGURA 53- Cultivo em alta densidade. Epitélios conservados em solução de formaldeído a 10\%. Abaixo de cada epitélio, quantidade de dia após a confluência. Método explante.

\subsection{Análise histológica dos epitélios cultivados}

A seguir nas FIG. 54 e 55 são mostradas imagens das lâminas contendo os cortes histológicos feitos com os epitélios cultivados (vide 5.6).

Essas lâminas foram confeccionadas após esses epitélios terem sido conservados em solução de formaldeído a 10\%, processados e corados com hematoxilina-eosina (vide 4.7). 

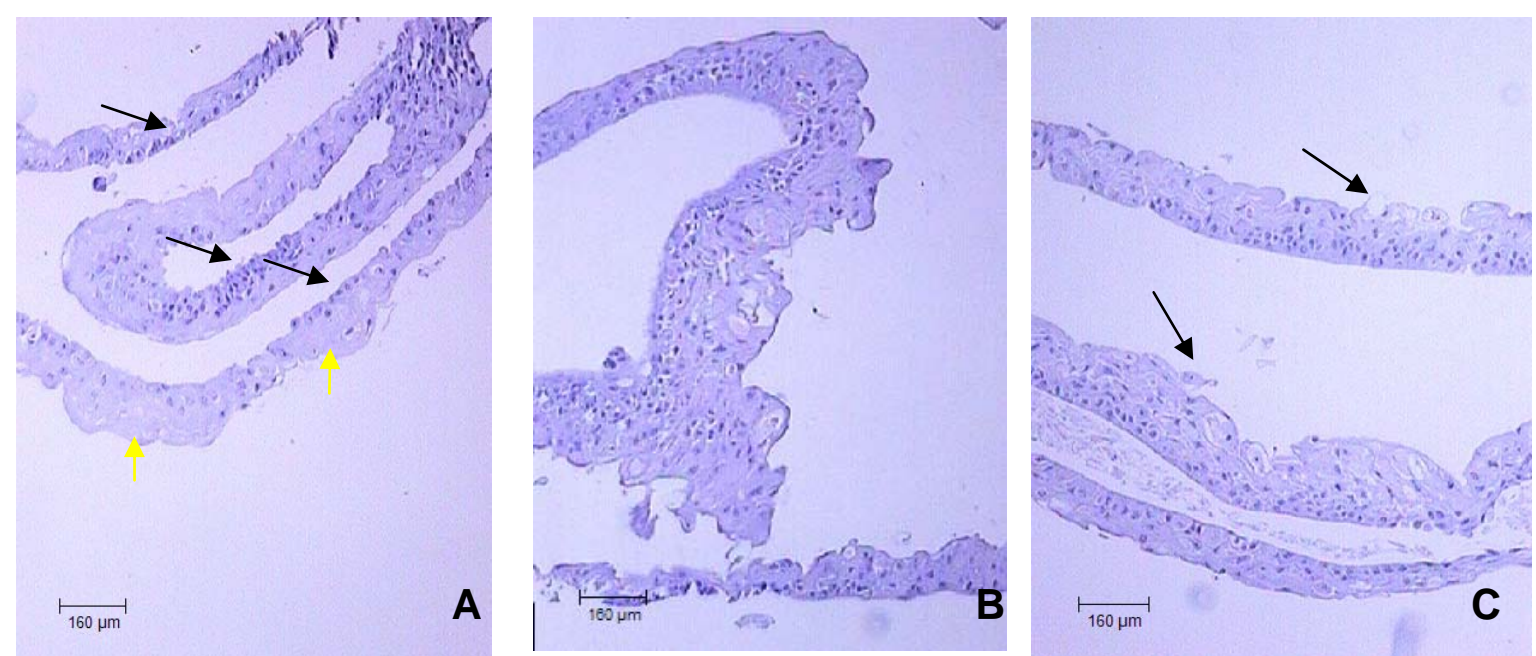

FIGURA 55- Imagens das lâminas com os cortes histológicos dos epitélios obtidos após diferentes dias de confluência dos queratinócitos em cultura, método explante. A) Após 1 dia de confluência, podemos notar estratificação com células basais (_) e diferenciação, com presença de células desprovidas de núcleos ( ), alta densidade; B) Após 12 dias de confluência, nota-se estratificação com maior quantidade de camadas celulares; C) Após 18 dias de confluência, nota-se além da estratificação e diferenciação, maior quantidade de descamação celular $\Upsilon_{\mathbf{Y}}$ ). Aumento de 10 vezes.

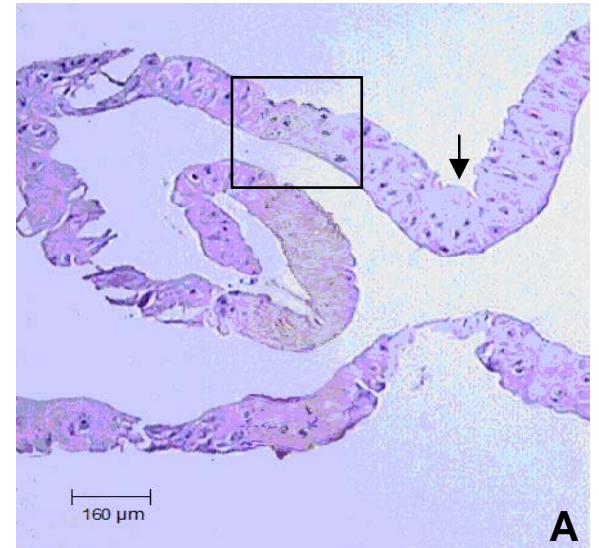

A

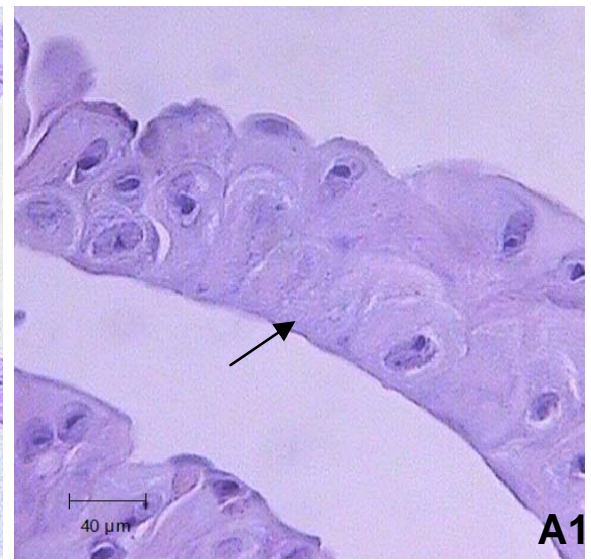

Epitélio formado após 21 dias de confluência.

A) Aumento de 10 vezes.

A1 ) Aumento de 40 vezes. 

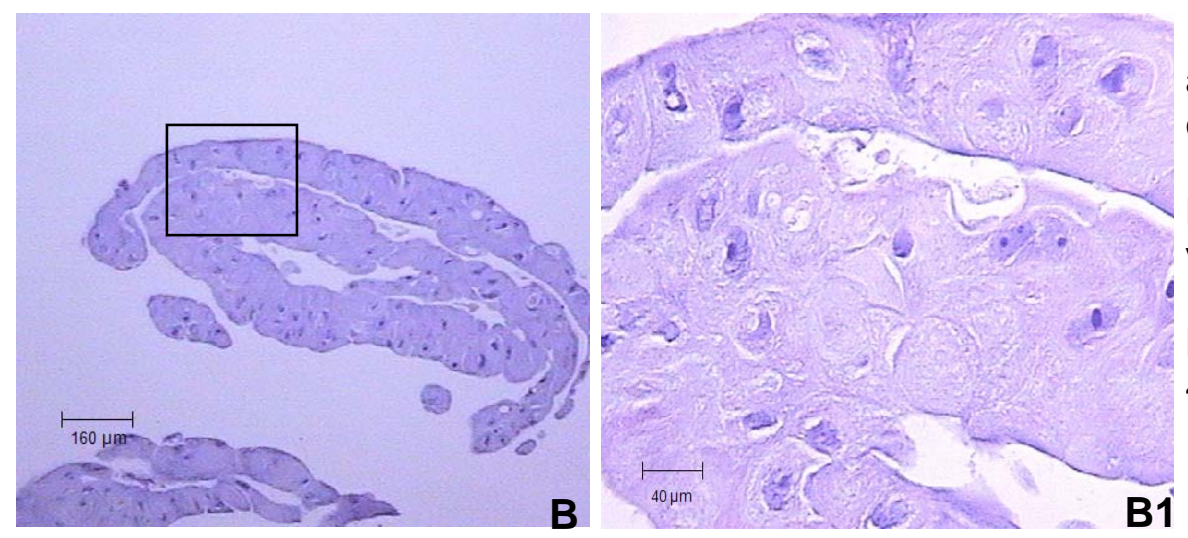

Epitélio formado após 28 dias de confluência.

B) Aumento de 10 vezes.

B1 ) Aumento de 40 vezes.

FIGURA 56- Imagens das lâminas com os cortes histológicos dos epitélios obtidos após a confluência dos queratinócitos em cultura, método enzimático. A) Presença de estratificação, com sinais de descamação e diferenciação com algumas células desprovidas de núcleos ( $\downarrow$ ); A1) Em aumento maior a região mostra duas ou três camadas de células, algumas desprovidas de núcleos (†); B) Como na imagem anterior, notamos a presença de estratificação e um estágio de diferenciação ainda maior, com maior quantidade de células desprovidas de núcleos; B1) Em aumento maior, podemos notar um estágio de diferenciação mais acentuado. 


\section{DISCUSSÃO}

O cultivo de queratinócitos provenientes de diversos tecidos vem sendo utilizado com vários propósitos [15, 27, 43, 53, 63], porém quando as células para a realização deste cultivo forem de origem bucal, algumas preocupações quanto ao cultivo começam a emergir. Dentre elas podemos destacar a obtenção de grande número de células clonogênicas, com alto rendimento. Esses cuidados são necessários, pois o tamanho da área a ser retirada, dentro da boca, será sempre reduzido, proporcionando pequenos fragmentos. Além disso, a preocupação em obter baixo nível de contaminação é enfatizada, pois o meio bucal é povoado por uma microbiota diversificada.

Inúmeras controvérsias, quanto aos métodos utilizados para a obtenção de células da mucosa bucal humana, ainda persistem. Neste sentido objetivamos contribuir com a padronização da obtenção e propagação destas células.

Na literatura encontramos vários tipos de protocolos diferentes quanto ao armazenamento, limpeza e assepsia dos fragmentos e utilização de antibióticos durante o cultivo celular $[31,32,33,47,53]$. A metodologia utilizada neste trabalho para o armazenamento e limpeza desses fragmentos demonstrou ter alcançado resultados bastante satisfatórios quanto ao nível de contaminação.

Podemos acrescentar ainda, que referente ao total dos fragmentos coletados, o número de amostras em que foi detectada presença de contaminação por microorganismos, provenientes dos próprios fragmentos, foi bastante baixo (dados não apresentados). Segundo Kedjarune [53], fonte para a realização deste trabalho, esse tipo de problema ocorreu com uma freqüência de 21\% para o método do explante e $8 \%$ para o método enzimático.

O epitélio de revestimento, o de maior abundância dentro do meio bucal [88], não foi o mais utilizado para a retirada dos fragmentos. Estes fragmentos eram dependentes dos tipos de cirurgias bucais realizadas, onde em sua maioria foi a remoção de terceiros molares inclusos. Por este ter sido um trabalho onde a colaboração dos pacientes voluntários foi a maior contribuição, esta retirada estava vinculada à necessidade cirúrgica particular de cada um. 
Este fato não foi relevante no presente trabalho, pois o objetivo deste foi comparar dois métodos quanto à eficiência na obtenção celular e avaliação da vitalidade das mesmas, e não terapêutico. Quando o cultivo for voltado ao objetivo terapêutico [57, 58, 59, 97], cabe analisar cada situação para objetivar a melhor conduta a ser tomada. Vários trabalhos, com propósitos científicos elegem os tipos de cirurgias aqui utilizados, para a obtenção desses fragmentos $[25,42,53$, $57,58,59]$.

O meio bucal, pela alta freqüência e velocidade na duplicação das células epiteliais (vide 3.5 ciclo celular) $[86,87]$, permite uma cicatrização rápida sem, portanto, deixar cicatrizes [57, 58], como ocorre com freqüência na epiderme. Entretanto, o local de retirada destes fragmentos, independente do objetivo da mesma, permanece restrito mesmo com todas as vantagens oferecidas pela cicatrização dentro do meio bucal [57, 58, 59, 97].

Para este trabalho houve total impossibilidade na determinação prévia do tamanho dos fragmentos coletados. Cada voluntário possuiu sua particularidade quanto à indicação, e coube a cada profissional, decidir quanto aos critérios e condutas cirúrgicas, desta maneira se explica a grande variação no tamanho dos fragmentos obtidos, sendo que a média foi de $0,65 \mathrm{~cm}^{2}$, porém variando de $0,12 \mathrm{~cm}^{2}$ a $2,00 \mathrm{~cm}^{2}$ (TAB. 2).

Na TAB. 3 estão mostrados os cálculos das medidas resumo referentes aos dados da TAB. 2, onde verificamos que apesar de obtermos fragmentos de até $2,3 \mathrm{~cm}^{2}, 75 \%$ dos fragmentos foram inferiores a $0,88 \mathrm{~cm}^{2}$, como encontrados no cálculo do terceiro quantil (IIIQ). Na FIG. 11 é mostrado em forma de histograma a distribuição dos valores contidos na TAB. 3.

Quanto à morfologia dos queratinócitos, pode-se observar (FIG. 12) já na primeira colheita, uma diferença no aspecto dessas células quando obtidas pelos diferentes métodos. No método enzimático essas células se apresentam com características morfológicas de células basais não diferenciadas (FIG. 12 A). Quando esses queratinócitos são obtidos pelo método do explante muitas vezes podem ser observados alguns sinais de diferenciação celular, traduzidos pelo aumento do volume destas células, ou ainda pelo aparecimento dos restos celulares, produto das células mortas (FIG. 12 B). 
Independente do objetivo do cultivo de queratinócitos, sempre procuramos obter células em maior quantidade e melhor qualidade, com grande capacidade clonogênica. Isto é mais preocupante quando se obtém essas células pelo método do explante, concordando com as conclusões de Breidahl [18] e Kedjarune [53], por esse exigir longo período e pela ausência da camada de sustentação, propiciando desta maneira a diferenciação celular, sendo este um processo irreversível $[51,78,80,83]$.

Ao monitorarmos a evolução da cultura primária ao microscópio ótico, uma grande diferença emerge entre os dois métodos (FIG. 12). No método enzimático, essas células devem atingir a sub-confluência, onde a camada de sustentação deverá estar quase que totalmente ausente e nenhum outro tipo de influência fará parte de nossa decisão do momento da tripsinização. Enquanto que no método do explante, por razões anteriormente descritas sempre haverá necessidade de inferir nas decisões do momento de retirada dessas células da placa de cultura. Muitas vezes nos deparamos com situações em que o rendimento celular se torna prejudicado, pois tivemos que optar pela retirada das células antes de obter maior quantidade das mesmas.

Com relação ao tempo para essa primeira colheita dos queratinócitos, na TAB. 4, podemos verificar que o método enzimático levou em média 11,9 dias e o método do explante 14,2 dias. Segundo a análise estatística, aplicando o teste t Student, o p-valor resultante foi 0.0088 , onde podemos interpretar que o número de dias necessário para se obter a primeira colheita dos queratinócitos pelo método do explante é significativamente maior do que pelo método enzimático [21]. Esta diferença de tempo entre os dois métodos pode ser observada na área cinza mostrada no gráfico da FIG. 13.

$\mathrm{Na}$ TAB. 5 verifica-se a diferença dos valores deste primeiro rendimento celular para cada um dos métodos avaliados. Para o método enzimático temos um valor médio de $4,35 \times 10^{6} / \mathrm{cm}^{2}$ enquanto que para o método do explante este valor cai para $6,52 \times 10^{5} / \mathrm{cm}^{2}$. Como discutido anteriormente, isto se deve ao fato de que muitas vezes não é possível atingir um número de células desejáveis no método do explante. No método enzimático, a camada de sustentação e o meio de cultura apropriado colaboram para evitar que essa diferenciação ocorra, proporcionando, desta maneira maior capacidade de 
duplicação dessas células [51, 78], discordando das conclusões de Kedjarune [53].

Outro fato, a ser mencionado no método do explante, é a perda de referencial visual, muito comum de se ocorrer. Quanto ao posicionamento destes fragmentos na placa, poderíamos acrescentar que a literatura mostra maneiras diferentes de posicioná-los [18, 53, 57, 58, 59], entretanto a não liberação das células é um fato a ser considerado. Sendo assim, segundo a metodologia utilizada para este trabalho, o rendimento celular desta primeira etapa, no método do explante, fica inferior quando comparamos com os resultados obtidos no método enzimático. Alguns autores divergem nas preferências entre os métodos $[18,53,57,58,59,106]$. Segundo Freshney [37], o método do explante deveria ser o escolhido quando a quantidade de material for escassa. Neste trabalho, os resultados apontam para uma outra direção, o p-valor resultante da análise estatística, pelo método de Wilcoxon [21], foi de 0,0000331 do qual interpreta-se que o rendimento celular na primeira colheita, pelo método enzimático é significativamente melhor quando comparado aos mesmos resultados obtidos no método do explante.

Quanto à evolução das células clonogênicas, podemos concluir, que em condições normais, o processo irreversível de senescência é traduzido pela diferenciação celular, onde ocorre a perda da capacidade proliferativa dos queratinócitos, impossibilitando-os de formar colônias. Isso ocorre tanto in vivo quanto in vitro $[43,51]$. Muitas vezes somente o aspecto macroscópico da colônia obtida (FIG. 14) não é suficiente para determinarmos o seu tipo (em desenvolvimento ou abortiva). Assim sendo, utilizamos os parâmetros microscópicos (FIG. 15) para melhor avaliação. Por meio destas classificações foi possível gerar a TAB. 6 e os gráficos mostrados nas FIG. 16 a 26.

$\mathrm{Na}$ TAB. 6 podemos observar uma variação nas porcentagens das colônias obtidas na primeira passagem (P1). Nos primeiros voluntários (V1 a V8) praticamente inexistem colônias abortivas para o método enzimático, exceto no voluntário 1. No método do explante, os cinco primeiros voluntários apresentaram colônias do tipo abortivas. No V10, ao contrário do que vem ocorrendo até o momento, o número de colônias abortivas para o método enzimático subiu para 15\% e o número de colônias totais encontradas no método explante foi superior 
ao número encontrado no método enzimático. Os resultados tendem a ser mais positivos para o método enzimático do que para o método explante, porém o número de amostras é pequeno. Também se observa que em vários casos (V10, V13 e V16) a porcentagem de colônias totais no método do explante supera os valores obtidos no método enzimático. Esses resultados estão mostrados em forma de gráfico na FIG. 16 e o p-valor foi de 0.0838. Este valor não é suficientemente pequeno para se concluir que existe diferença com significância estatística, ou seja, em uma porcentagem razoavelmente grande a diferença entre os dois métodos é muito pequena. De forma análoga pode-se concluir que as diferenças entre os dois métodos avaliados em relação às colônias abortivas também não apresentam significância estatística, aproximadamente a metade das observações é diferente e a outra metade é igual (TAB. 6), dando um valor final igual a zero.

Nas FIG. 17 a 26 podemos observar, por meio dos gráficos apresentados, a quantidade dos dois tipos de colônias: em desenvolvimento (linha vermelha), abortiva (linha verde), e a soma das duas anteriores, originando a quantidade de colônias totais (linha azul). A representação gráfica mostra uma situação de normalidade, onde à medida que essas células evoluíram em cultura, o número de colônias em desenvolvimento diminuiu e conseqüentemente o número das colônias abortivas aumentou, mas apesar disto a tendência é que, com o aumento do número de passagens, o número total das colônias diminua. Para os voluntários 1 e 2 foi possível acompanhar todo o tempo de vida celular em cultura, enquanto que para os demais, estes dados foram parciais, pois a evolução foi interrompida, antes de sua finalização. Na FIG.18 B o gráfico mostra que houve muito pouca colônia em desenvolvimento, o que também está representado na $T A B$. 6. Os prováveis motivos para este fato serão discutidos posteriormente (pag. 101). Nas FIG. 21 e 23 não foram apresentados os gráficos referentes ao método do explante, pois não houve desenvolvimento das células em cultura. Na FIG. 22B nas duas primeiras passagens e na FIG. 24 B nas cinco passagens realizadas, o gráfico mostra que foram encontradas somente colônias do tipo em desenvolvimento. Na FIG. 25B o gráfico mostra que o número de colônias encontrado foi muito baixo. Nesta situação poderíamos ter optado por semear maior quantidade de células para a realização deste teste. Na FIG. 26 o 
gráfico mostra que não foi possível a realização deste teste para o método do explante, pois não houve rendimento celular suficiente.

As eficiências de formação de colônias, apresentadas na seqüência de gráficos das FIG. 17 a 26, refletem o desenvolvimento destas células em cultura, durante sua vida útil (life-span).

Quando, a partir de um mesmo fragmento, se obtém duas amostras para a realização de testes comparativos, como neste caso, torna-se impossível determinar se as frações possuirão as mesmas quantidades de células clonogênicas (vide 3.1, 3.2.1) [10, 26, 85, 93]. As células tronco epiteliais, denominadas, células mãe ou holoclones $[5,6,7,60,78,79]$, estão distribuídas ao longo da camada basal (vide 3.1, 3.2.1) [10, 26, 85, 93], entretanto, sua localização é de difícil determinação. Isso pode ter sido um dos motivos para as diferenças, aqui observadas, na quantidade e qualidade das colônias do mesmo voluntário, porém provenientes de dois métodos de obtenção celular diferente.

Quanto ao teste "Tempo de vida celular" (life-span), além de nos mostrar o tempo de sobrevivência dessas células, nos informa o número de duplicações efetuado por meio da atividade das mesmas em cultura. O número de duplicações iniciais para o método do explante é calculado por extrapolação dos resultados, pois para se calcular este número é necessário o $\mathrm{N}_{0}$, e este só é possível de ser obtido, por meio do número de colônias resultante daquela passagem (vide 4.4 e 4.5 equação 1). No método do explante as células inicialmente migram a partir dos fragmentos para fora deste. Este fato inviabiliza a realização do teste de EFC desta primeira obtenção celular. No método enzimático, a aproximação deste número se torna mais verdadeira, pois durante a primeira colheita realizada, é possível semear células tanto para o cultivo celular, quanto para a realização do teste de EFC. O que não podemos determinar neste momento, é a quantidade exata de queratinócitos que estamos semeando, pois durante esta primeira colheita de células, outros tipos celulares estão presentes, porém a camada de sustentação juntamente com o meio de cultura apropriado acaba por selecionar as células que se deseja cultivar, no caso, os queratinócitos $[27,28,29,40,42,45,63]$.

Com exceção dos voluntários 1 e 2, não foi possível chegar ao final da vida útil em cultura para os demais voluntários. Observando os resultados 
contidos nas TAB. 7 a 20 e mostrados nos gráficos das FIG. 27, 29, 30, 32, 34, 35, 37 a 44, podemos acrescentar o mesmo comentário, feito anteriormente, quanto a quantidade de células com maior potencial clonogênicos possivelmente presentes nos fragmentos, pois isso poderia ser um dos motivos dos diferentes resultados encontrados no presente teste.

Observamos na TAB. 7 e na FIG. 27 que o tempo de vida celular e o número de duplicações foram praticamente o dobro para o método do explante em comparação ao método enzimático. Na FIG. 28, a área ilustrada pela cor cinza, representa a diferença do comportamento celular entre os dois métodos. Neste caso foi feita uma análise estatística e chegamos ao p-valor de 0,01766664, o que significa que esse valor não é estatisticamente significativo. Estes valores são muito próximos até o $68^{\circ}$ dia, o que se observa claramente na TAB. 7 e nos gráficos contidos nas FIG. 27 e 28. Sendo que a estatística utilizada foi unicamente comparativa, podemos concluir que ambos os métodos tiveram número de duplicações iguais até o $65^{\circ}$ dia, porém é visível a diferença, neste caso entre os dois métodos, quando observamos que após o $68^{\circ}$ dia, não houve mais duplicação celular nas células obtidas pelo método enzimático e as células obtidas pelo método do explante, duplicaram até o $135^{\circ}$ dia.

$\mathrm{Na}$ TAB. 8 e na FIG.29, esta situação se inverte, porém cabe acrescentar que o tipo de cirurgia a que este voluntário se submeteu (vide TAB. 1) nos informa sobre as condições inflamatórias locais. Este fato teria contra indicado esta amostra para o presente trabalho, entretanto podemos encontrar na literatura respostas para tais situações (vide 3.5) [86, 88]. Apesar destas condições, o tempo de vida celular em cultura foi finalizado e foi possível visualizar diferenças nos resultados obtidos entre os dois métodos.

Na TAB. 9 e na FIG. 30 observa-se tanto no tempo, quanto no número de duplicações, resultados bastante semelhantes, não mostrando diferenças significativas entre os dois métodos comparados. Isto é ilustrado na FIG. 31, onde se observa que a área cinza não é tão visível, as linhas chegando até a se entremearem no final do gráfico. Portanto não podemos afirmar que existem diferenças significativas entre os dois métodos. O p-valor calculado foi de 0,1000514 , concordando com os resultados obtidos até o momento. O tempo de vida celular (life-span), não foi finalizado, sendo assim, embora outros resultados 
mostrem que não há diferença estatisticamente significativa, não seria possível no presente momento, prever qual o método que efetuará o maior número de duplicações.

Na TAB. 10 e nas FIG. 32 e 33, situações semelhantes são mostradas, agora com o p-valor de 0,001341897, como no caso anterior, mostrando diferença estatisticamente significativa entre os dois métodos.

Nas TAB. 11 e 13 e nas FIG. 34 e 37 não foi possível a comparação entre os dois métodos, pois não houve migração celular a partir do explante. Porém foi dada continuidade ao cultivo das células a fim de testar a viabilidade das mesmas.

Pudemos observar, que apesar da dificuldade encontrada na obtenção celular pelo método do explante, as células obtidas pelo método enzimático, se desenvolveram satisfatoriamente, com um potencial de duplicação inferior a 23 horas em ambos casos.

Observando os resultados obtidos na TAB. 12 e nas FIG.35 e 36, podemos notar que na FIG. 36 a área cinza agora acentuada, mostra uma diferença entre os dois métodos, o que pode ser também concluído com o p-valor calculado de 0,0006460338.

Segundo as análises estatísticas, só são significativos os resultados obtidos com os voluntários 5 e 8 (TAB. 10 e 12), onde os valores de p são menores ou aproximadamente iguais a 0,001. Podemos notar que só nestes dois casos os gráficos são diferentes, sendo maior a diferença para o voluntário 8. Para o voluntário 1 (TAB. 7), esses valores são muito similares e o p-valor não tão baixo. Para o voluntário 3 (TAB. 9), os valores são semelhantes, o que torna também o p-valor pouco significativo.

Nas TAB. 10 e 14 e nas FIG. 32 e 38 notamos que as células iniciaram as duplicações em situações semelhantes, mas que a diferença se faz notar por volta do sexagésimo dia para o V5 e por volta do quadragésimo dia para o V10. Embora ambos os casos não chegaram ao final da vida útil em cultura, podemos notar até aqui que em 106 dias tivemos por volta de 127 duplicações para o método enzimático e em 110 dias por volta de 116 duplicações para o método do explante no voluntário 5 . No voluntário 10, em 42 dias tivemos por volta de 49 
duplicações no método enzimático e em 45 dias por volta de 47 duplicações. Diferentemente do desenvolvimento encontrado, por exemplo, para as células do voluntário 8 (TAB. 12), onde esta diferença já é notada desde os primeiros dias.

Para se comparar estatisticamente as diferenças entre os dois métodos haveria necessidade de ter tido um número mínimo de sete passagens. Isso não foi possível, ficando apenas registrado, em alguns dos casos (TAB. 8, 11, 13 a 20), por meio dos dados obtidos, a possibilidade dessas células se manterem e se duplicarem em cultura, as vezes de maneira inesperada, como no caso do voluntário 16 (TAB. 17 e FIG. 41), onde o tempo de duplicação das células obtidas pelo método do explante foi inferior a 16 horas.

Kang, em 2000, refere que o tempo de duplicação celular, seria em torno de 26,6 horas [51]. Sob as condições de cultivo realizadas neste trabalho, estes números apresentaram uma grande variação (dados contidos abaixo de cada tabela). Ainda outras informações encontradas na literatura descrevem que o número máximo de duplicações obtidas pelas células em cultura varia entre 5,7 a 45,2 duplicações, podendo variar particularmente para cada doador [51]. Em alguns casos, nas nossas condições de trabalho, esses números chegaram a ultrapassar esses valores, mesmo nos casos não finalizados.

O tempo de vida celular em cultivo de queratinócitos, também foi efetuado com estas células semeadas em alta densidade. Para este teste foi utilizado o mesmo meio de cultura utilizado até o momento $(\mathrm{K}+)[9,11,12,15,18$, 19, 25, 34, 40, 42, 43, 44, 45, 63, 70, 77, 78, 79, 90, 91, 92, 104, 106, 108], porém essas células foram semeadas sem a utilização da camada de sustentação $[8,45$, $53,63,70,77,78,103]$. De acordo com a literatura, há uma diminuição do tempo e do número de duplicações dos queratinócitos em cultura. As células utilizadas para a realização deste teste, foram do voluntário 5 , as mesmas que, em condições onde foi utilizada a camada de sustentação, chegaram até 127 duplicações em 106 dias no método enzimático e 116 duplicações em 110 dias no método do explante (mesmo antes de ter atingido o final da vida útil em cultura). Neste caso, esses números ficaram reduzidos a 24 dias com 30 duplicações no método enzimático e 24 dias com 11 duplicações no método de explante. Essas células, ao contrário do ocorrido com a utilização da camada de sustentação, diminuem suas quantidades necessitando ser semeadas em áreas cada vez 
menores, concordando com as conclusões de Breidahl [18]. Os resultados estão mostrados na TAB. 21 e na FIG. 45 e na FIG. 46, onde podemos notar a mudança na morfologia celular, resultado do processo de diferenciação dos queratinócitos [5, 28, 29, 30, 31, 51], inclusive com dificuldades em atingir a confluência celular, principalmente no método do explante e neste caso o tempo de vida celular em cultivo de queratinócitos feito em alta densidade, porém com meio K-SFM [4, 92, 98, 100]. Para esse teste foram utilizadas as mesmas condições do teste anterior, apenas o meio de cultura utilizado foi substituído por um outro meio sem a suplementação de soro animal. Primeiramente, como podemos observar na FIG. 47, o aspecto morfológico dos queratinócitos foi mantido durante a primeira passagem ( $P 2$ ) realizada com este meio. No método enzimático foi possível atingir duas vezes a sub-confluência, porém no método do explante isso não foi possível. Na segunda tripsinização e tentativa de cultivo, para o método enzimático, não houve mais adesão das células à superfície de cultivo. Foi feita mais uma tentativa de cultivo, descongelando essas células e semeando diretamente com o meio K-SFM, não sendo possível a adesão celular (dados não apresentados). Para as células provenientes do método do explante, a partir do segundo cultivo, deu-se início ao aparecimento de melanócitos, não havendo mais duplicações por parte dos queratinócitos. Zhu em 2004, descreve em seu trabalho o meio K-SFM, com algumas modificações, para a obtenção de melanócitos [108]. Outros autores como Barnes, Freshney, Takashi, Wille Jr., Yoshizawa e Zhu ainda descrevem a combinação de concentrações baixas de soro bovino ao meio de cultura e sua retirada durante as trocas de meio. Sabe-se da importância do soro na adesão das células à superfície de cultivo [4, 36, 92, $100,105,108]$.

Quanto à confecção dos epitélios formados a partir da confluência dos queratinócitos bucais cultivados, podemos observar pelos resultados obtidos mostrados nas imagens das FIG. 48 a 53, que isso é possível com queratinócitos bucais, assim como com a pele chegando a resultados compatíveis com os resultados de vários autores $[3,57,58,59,90,91,95,96,102]$. Esta obtenção foi possível pelos dois métodos de obtenção celular. As células atingiram a confluência em ambos métodos e em ambas técnicas de cultivo, ou seja, alta densidade ou sobre camada de sustentação (FIG. 48 e 49). Discordando, desta 
maneira, com as conclusões de Breidahl [18], quando descreve que não é possível a confecção de epitélios estratificados, quando as células são cultivadas em alta densidade. Podemos observar, por meio das imagens obtidas durante o cultivo, que essas células vão se estratificando, se diferenciando e no final vão se descamando, iniciando a formação de bolhas microscópicas, e por volta do $28^{\circ}$ dia após a confluência, as mesmas começam a se desprender da superfície de cultivo, como é mostrado na FIG. 50. Este fato se reflete em epitélios falhos, quando destacados da placa de cultivo, por meio da ação da enzima dispase, como pode ser visualizado na FIG. 51. Estes epitélios possuem aparência semelhante (FIG. 52 e 53) àqueles apresentados na literatura, em vários trabalhos sobre epitélios transplantáveis com fins terapêuticos, obtidos por meio do cultivo de queratinócitos in vitro [12, 40, 61, 89]. Estes testes devem ser repetidos com células de outros pacientes e com outras culturas primárias, para confirmar a reprodutibilidade destes resultados.

Para termos certeza se estes epitélios obtidos sob as condições de cultivo realizadas para este trabalho, são ou não transplantáveis, outros testes deveriam ser realizados.

Os epitélios formados foram histologicamente analisados, após a conservação em solução de formaldeído a 10\%. Nas FIG. 54 e 55, estão mostradas algumas imagens destas lâminas contendo os cortes histológicos, onde podemos notar, em aumento, estratificação e diferenciação com o decorrer do tempo de confluência. Em algumas das lâminas podemos notar o processo de descamação, que se torna evidente depois de alguns dias, após ter atingido a confluência. Para termos certeza da presença de várias estruturas e componentes estruturais dos queratinócitos, teríamos que lançar mão de outros tipos de testes, tais como imunohistoquímica e microscopia eletrônica.

Quanto aos métodos aqui analisados, podemos acrescentar que cada um deles oferece vantagens e desvantagens. Vários dos trabalhos encontrados na literatura apontam preferências pela metodologia do explante, prioridade esta, contrária aos resultados obtidos neste trabalho $[18,37,53,57,58,59]$. Com relação às preferências, pode ser acrescentado que muitas vezes os objetivos do cultivo dos queratinócitos podem direcionar tais preferências, como descreve Breidahl nas conclusões de seu trabalho [18]. As nossas conclusões discordam 
de Freshney [37], quando este indica o método de explante na escassez de material para o cultivo. Nossa discordância é enfatizada quando demonstramos que nem todos os fragmentos posicionados na placa de cultivo liberam células, concordando com os resultados encontrados no trabalho de Kedjarune [53], embora o autor em suas conclusões relate melhores resultados com o método do explante.

Breidahl em seu trabalho de 1989 [18], descreve algumas vantagens e desvantagens na utilização de ambos métodos. Avaliando nosso dados obtidos também encontramos vantagens e desvantagens em ambos métodos, porém algumas vezes concordando outras não com Breidahl. Poderíamos citar a longa duração do procedimento inicial, no método enzimático, assim como a necessidade de preparação prévia da camada de sustentação, neste caso concordando com Breidahl. Porém este ainda descreve a necessidade de maior investimento de tempo para se obter a multiplicação dos queratinócitos, discordando de nossos resultados, onde utilizando o método enzimático, provamos ser possível obter maior rendimento celular em espaço de tempo menor do que as células obtidas pelo método do explante. Por sua vez a camada de sustentação previne a presença indesejada de outros tipos celulares, como os fibroblastos, além desta mesma ser necessária para a propagação posterior destas células em cultura, independente do método utilizado para a obtenção celular. 


\section{CONCLUSÂO}

Sob as condições de trabalho obtidas para a realização da cultura primária de queratinócitos bucais humanos, o método que apresentou os melhores resultados foi o método enzimático.

Por meio deste, podemos obter maior rendimento celular em espaço de tempo menor do que as células obtidas pelo método do explante.

O envolvimento de manipulação técnica empregada, no método do explante, inicialmente é menor que para o método enzimático. Outra vantagem desse método é a de não necessitar da camada de sustentação para a obtenção inicial das células. Entretanto quando se deseja a propagação dessas células, a utilização desta camada torna-se necessária, além desta auxiliar na prevenção da contaminação da cultura de queratinócitos, por células indesejáveis, neste caso, os fibroblastos. Sob as condições de trabalho utilizadas, esse tipo de contaminação não ocorreu em ambos os métodos.

A utilização de ambos os protocolos de cultivo mostrou-se adequada para a obtenção e propagação dos queratinócitos bucais em cultura, com a possibilidade de formação de epitélios estratificados. 


\section{APÊNDICE A - Questionário informativo}

\section{FICHA CONTROLE DO PACIENTE}

$B H K N^{\circ}$

Nome do Paciente:

Data de nascimento: Idade:

Cor

Profissão:

Função desenvolvida no Trabalho:

Tipo de cirurgia:

Local de retirada do fragmento:

Data da cirurgia:

Local de tratamento:

Nome do profissional:

Tamanho do fragmento:

$$
\text { Enfermidades }
$$

agudas

crônicas:

Doenças $\quad$ sistêmicas: $\quad(\quad) \quad \operatorname{sim},(\quad) \quad$ )
não.Quais:

Uso terapêutico:

Fumante: ( ) sim ( ) não

$$
\text { Álcool: () sim () não }
$$

Drogas () sim ()não

Especificar

Hábitos:

Antecedentes Familiares: (câncer, ou alguma enfermidade auto imune)

Observações: 
APÊNDICE B - Porcentagem de colônias em desenvolvimento e colônias abortivas de cada voluntários referente a cada método

\begin{tabular}{|c|c|c|c|c|c|c|c|c|c|c|c|c|c|c|c|c|c|c|c|c|c|c|c|c|}
\hline & \multicolumn{4}{|c|}{ V1 } & \multicolumn{4}{|c|}{ V2 } & \multicolumn{4}{|c|}{ V3 } & \multicolumn{4}{|c|}{ V5 } & \multicolumn{2}{|c|}{ V6 } & \multicolumn{4}{|c|}{ V8 } & \multicolumn{2}{|c|}{ V9 } \\
\hline & $\begin{array}{c}\text { Enz. } \\
\text { Des. } \\
\%\end{array}$ & $\begin{array}{c}\text { Enz. } \\
\text { Ab. } \\
\%\end{array}$ & $\begin{array}{c}\text { Expl } \\
\text { Des. } \\
\%\end{array}$ & $\begin{array}{c}\text { Expl } \\
\text { Ab. } \\
\%\end{array}$ & $\begin{array}{c}\text { Enz. } \\
\text { Des. } \\
\%\end{array}$ & $\begin{array}{c}\text { Enz. } \\
\text { Ab. } \\
\%\end{array}$ & $\begin{array}{c}\text { Expl } \\
\text { Des. } \\
\%\end{array}$ & $\begin{array}{c}\text { Expl } \\
\text { Ab. } \\
\%\end{array}$ & $\begin{array}{c}\text { Enz. } \\
\text { Des. } \\
\%\end{array}$ & $\begin{array}{c}\text { Enz. } \\
\text { Ab. } \\
\%\end{array}$ & $\begin{array}{c}\text { Expl } \\
\text { Des. } \\
\%\end{array}$ & $\begin{array}{c}\text { Expl } \\
\text { Ab. } \\
\%\end{array}$ & $\begin{array}{c}\text { Enz } \\
\text { Des. } \\
\%\end{array}$ & $\begin{array}{c}\text { Enzl } \\
\text { Ab. } \\
\%\end{array}$ & $\begin{array}{c}\text { Expl } \\
\text { Des. } \\
\%\end{array}$ & $\begin{array}{c}\text { Expl } \\
\text { Ab. } \\
\%\end{array}$ & $\begin{array}{c}\text { Enz } \\
\text { Des. } \\
\%\end{array}$ & $\begin{array}{c}\text { Enzl } \\
\text { Ab. } \\
\%\end{array}$ & $\begin{array}{c}\text { Enz } \\
\text { Des. } \\
\%\end{array}$ & $\begin{array}{c}\text { Enzl } \\
\text { Ab. } \\
\%\end{array}$ & $\begin{array}{c}\text { Expl } \\
\text { Des. } \\
\%\end{array}$ & $\begin{array}{c}\text { Expl } \\
\text { Ab. } \\
\%\end{array}$ & $\begin{array}{c}\text { Enz } \\
\text { Des. } \\
\%\end{array}$ & $\begin{array}{c}\text { Enz } \\
\text { Ab. } \\
\%\end{array}$ \\
\hline P1 & 43 & 1,5 & 38 & 15,5 & 0,5 & 0 & 0 & 0,5 & 100 & 0 & 47,5 & 11 & 78 & 0 & 20 & 13 & 48,5 & 0 & 28 & 0 & 16,5 & 0,5 & 58 & 0 \\
\hline P2 & 31 & 3 & 9,5 & 4 & 10,5 & 3 & 0,5 & 2,1 & 76,5 & 9 & 19,5 & 17 & 62 & 8 & 12,5 & 5,75 & 25 & 12,5 & 100 & 0 & 23 & 0 & 38,5 & 0 \\
\hline P3 & 13,5 & 6 & 45 & 19,5 & 1,3 & 0,43 & 0 & 0,2 & 31 & 13,5 & 20 & 9 & 37 & 6,5 & 55 & 15 & 61 & 10 & 31,5 & 13,5 & 17 & 0 & 57,5 & 15 \\
\hline P4 & 48 & 25,5 & 0,25 & 0,25 & 5 & 1,3 & & & 16 & 16,5 & 83 & 0 & 31 & 12,5 & 11,5 & 14,5 & 2,5 & 0 & 15,5 & 2 & 2 & 0 & 10 & 3 \\
\hline P5 & 16,3 & 9 & 0,5 & 3,75 & 4 & 1 & & & 6,5 & 7 & 20 & 6,25 & 12,5 & 13 & 6,5 & 12,8 & 7,75 & 2,75 & 1 & 0 & 2,5 & 0,25 & 6,25 & 5,2 \\
\hline P6 & 3 & 2,8 & 3,9 & 4,4 & 1 & 0,6 & & & 4,5 & 2,6 & 22 & 7,5 & 6 & 2,25 & 8 & 1,5 & 3,8 & 2,4 & 3,25 & 1,5 & 1,4 & 0,1 & 1,75 & 2 \\
\hline P7 & 1,3 & 0,6 & 7,3 & 7,4 & 1,5 & 0,5 & & & 7 & 8,25 & 13,5 & 9,75 & 5,5 & 2,5 & 12,7 & 10,2 & 8,75 & 3,75 & 9,1 & 4,7 & 0,4 & 0 & 2 & 3,5 \\
\hline P8 & 0 & 0 & 3,4 & 5 & 0,5 & 0,4 & & & 9,5 & 2,5 & 11,5 & 6,12 & 6,25 & 2,25 & 16,4 & 2,29 & 8 & 2,1 & 8,6 & 1,7 & & & 17 & 2,2 \\
\hline P9 & 0,2 & 0,2 & 17,7 & 2,7 & 0,5 & & & & 13,5 & 2,75 & 13,8 & 3,3 & 18,3 & 34,7 & 5,8 & 8,31 & 11 & 2,7 & 10,1 & 1,4 & & & 10,5 & 2,3 \\
\hline P10 & 0 & 0,15 & 0,1 & 0,3 & 10,5 & 3 & & & 4,35 & 3,38 & 6,1 & 2 & 16,2 & 0,7 & 6,28 & 6,7 & 4,65 & 1,15 & 8,75 & 2 & & & 9,7 & 3 \\
\hline P11 & & & 1,25 & 1 & & & & & & & 13,7 & 5,3 & 5,25 & 0,89 & 4,43 & 7,83 & 4,27 & 1,5 & 28 & 0 & & & 10,3 & 0,5 \\
\hline P12 & & & 0,8 & 0,7 & & & & & & & & 4,5 & 10,5 & 9 & 11,2 & 1,77 & & & 100 & 0 & & & & \\
\hline P13 & & & 1,55 & 2,1 & & & & & & & 47,5 & 11 & 26,9 & 7,5 & 8,02 & 2,38 & & & & & & & & \\
\hline P14 & & & 0 & 0,1 & & & & & & & 19,5 & 17 & 30 & 0 & 6,3 & 1,2 & & & & & & & & \\
\hline P15 & & & 0,41 & 0,26 & & & & & & & 20 & 9 & 6,5 & 2 & 4,54 & 0 & & & & & & & & \\
\hline P16 & & & 0,13 & 4,14 & & & & & & & & & 25,4 & 3,86 & 12 & 1 & & & & & & & & \\
\hline P17 & & & 0,17 & 0,64 & & & & & & & & & 13,5 & 8,26 & 20,7 & 1,6 & & & & & & & & \\
\hline P18 & & & 0,15 & 0,42 & & & & & & & & & 23,5 & 1,17 & 0,8 & 0,8 & & & & & & & & \\
\hline P19 & & & 0,03 & 0,2 & & & & & & & & & 13,5 & 2,9 & & & & & & & & & & \\
\hline P20 & & & 0 & 0,01 & & & & & & & & & 31,9 & 5,63 & & & & & & & & & & \\
\hline
\end{tabular}


APÊNDICE B - Porcentagem de colônias em desenvolvimento e colônias abortivas de cada voluntários referente a cada método

\begin{tabular}{l|cccccccccccc}
\hline & \multicolumn{4}{|c}{ V10 } & \multicolumn{1}{c}{ V32 } & \multicolumn{4}{c}{ V34 } \\
\hline & Enz. & Enz. & Expl & Expl & Enz. & Enz. & Expl & Expl & Enz. & Enz. & Expl & Expl \\
& Des. & Ab. & Des. & Ab. & Des. & Ab. & Des. & Ab. & Des. & Ab. & Des. & Ab. \\
& $\%$ & $\%$ & $\%$ & $\%$ & $\%$ & $\%$ & $\%$ & $\%$ & $\%$ & $\%$ & $\%$ & $\%$ \\
P1 & 44,5 & 0 & 35 & 0 & & & 84 & 0 & 21,5 & 0 & 0 & 0 \\
P2 & 29 & 15,5 & 89 & 0 & 0,58 & 0,3 & 48,4 & 0 & 74 & 7,7 & 0 & 9,4 \\
P3 & 18,5 & 7 & 27,5 & 0 & 0 & 0,41 & 34,5 & 11,4 & 19,4 & 1,8 & 0 & 14,6 \\
P4 & 11 & 5,2 & 4,5 & 0 & & & 13 & 16,6 & 33,1 & 11, & 0 & 0,85 \\
P5 & 1,2 & 0 & 4,5 & 0 & & & 1,53 & 0,64 & 1,7 & 0 & & \\
P6 & & 0,5 & & & & & 84 & 0 & 0,99 & 7,9 & & \\
\hline
\end{tabular}


APÊNDICE C - Quantidade de colônias totais de cada voluntários para cada método

\begin{tabular}{|c|c|c|c|c|c|c|c|c|c|c|c|c|c|c|}
\hline & \multicolumn{2}{|c|}{ V 01} & \multicolumn{2}{|c|}{ V.02 } & \multicolumn{2}{|c|}{ V 03} & \multicolumn{2}{|c|}{ V 05} & \multirow{2}{*}{$\begin{array}{c}\text { V06 } \\
\text { Enz. } \\
\%\end{array}$} & \multicolumn{2}{|c|}{ V 08} & \multirow{2}{*}{$\begin{array}{c}\text { V } 09 \\
\begin{array}{c}\text { Enz. } \\
\%\end{array}\end{array}$} & \multicolumn{2}{|c|}{ V10 } \\
\hline Passag & $\begin{array}{c}\text { Enz. } \\
\%\end{array}$ & $\begin{array}{c}\text { Exp } \\
\%\end{array}$ & $\begin{array}{c}\text { Enz } \\
\%\end{array}$ & $\begin{array}{c}\text { Exp } \\
\%\end{array}$ & $\begin{array}{c}\text { Enz. } \\
\%\end{array}$ & $\begin{array}{c}\text { Exp } \\
\%\end{array}$ & $\begin{array}{c}\text { Enz. } \\
\%\end{array}$ & $\begin{array}{c}\text { Exp } \\
\%\end{array}$ & & $\begin{array}{c}\text { Enz. } \\
\%\end{array}$ & $\begin{array}{c}\text { Expl } \\
\%\end{array}$ & & $\begin{array}{c}\text { Enz. } \\
\%\end{array}$ & $\begin{array}{c}\text { Exp } \\
\%\end{array}$ \\
\hline P1 & & & 13. & & & & & & & & & & & \\
\hline & 45 & 53 & 5 & 0.5 & 100 & 58.5 & 78 & 33 & 2.45 & 28 & 17 & 58 & 44,5 & 35 \\
\hline P2 & 34 & 13.5 & 1.7 & 2.6 & 85,5 & 36.5 & 10 & 18,2 & 48.5 & 100 & 23 & 38,5 & 25,5 & 89 \\
\hline P3 & 18. & 64 & 1.6 & 0.2 & 44,5 & 20 & 43,5 & 70 & 37.5 & 45 & 6,55 & 72,5 & 33 & 27,5 \\
\hline P4 & 73. & 4.2 & 5.3 & & 37,5 & 83 & 83 & 4,05 & 71 & 15,5 & 17 & 6,95 & 13,7 & 4,5 \\
\hline P5 & 3.5 & 8.3 & 5 & & 13,5 & 26,2 & 22,5 & 26 & 2.5 & 100 & 4 & 13 & 3 & \\
\hline P6 & 12 & 14. & 1.6 & & 7,3 & 29,5 & 8,25 & 19,2 & 2.4 & 4,75 & 2,75 & 11,5 & 1,16 & \\
\hline P7 & 25. & 8.4 & 2 & & 15,2 & 23,5 & 8 & 9,5 & 10.5 & 13,8 & 1,5 & 3,75 & & \\
\hline P8 & 5.8 & 20. & 0,9 & & 7,25 & 17,6 & 12,5 & 23 & 6.2 & 10,3 & 0,4 & 5,5 & & \\
\hline P9 & 1.9 & 0.4 & & & 9,5 & 16,1 & 21,2 & 18,7 & 12.5 & 11,5 & & 19,1 & & \\
\hline P10 & 0 & 1.1 & & & 7,74 & 8,1 & 17 & 14,1 & 10.1 & 10,7 & & 12,8 & & \\
\hline P11 & & 1.5 & & & 6,9 & 19 & 6,14 & 13 & 13.7 & & & 12,7 & & \\
\hline $\mathrm{P} 12$ & & 3.6 & & & 6,5 & & 15 & 12,3 & 5.8 & & & 10,8 & & \\
\hline $\mathrm{P} 13$ & & 0.1 & & & 6,25 & & 34,4 & 13 & 5.7 & & & & & \\
\hline P14 & & 0.13 & & & 2,9 & & 33 & 10,5 & 2.45 & & & & & \\
\hline P15 & & 0.6 & & & & & 8,5 & & 48.5 & & & & & \\
\hline P16 & & 7.4 & & & & & 29,3 & & 37.5 & & & & & \\
\hline P17 & & 0.8 & & & & & 21,8 & & & & & & & \\
\hline P18 & & 0.5 & & & & & 22,3 & & & & & & & \\
\hline P19 & & 0.2 & & & & & 37,5 & & & & & & & \\
\hline P20 & & 0.01 & & & & & 15,6 & & & & & & & \\
\hline
\end{tabular}


APÊNDICE C - Quantidade de colônias totais de cada voluntários para cada método

\begin{tabular}{|c|c|c|c|c|c|c|c|c|c|c|c|c|c|c|}
\hline \multirow[b]{2}{*}{ Passag } & \multicolumn{2}{|c|}{ V 11} & \multicolumn{2}{|c|}{ V 15} & \multicolumn{2}{|c|}{ V 16} & \multicolumn{2}{|c|}{ V 31} & \multicolumn{2}{|c|}{ V32 } & \multicolumn{2}{|c|}{ V 33} & \multicolumn{2}{|c|}{ A.D. } \\
\hline & $\begin{array}{c}\text { Enz. } \\
\%\end{array}$ & $\begin{array}{c}\text { Exp } \\
\%\end{array}$ & $\begin{array}{c}\text { Enz. } \\
\%\end{array}$ & $\begin{array}{c}\text { Exp } \\
\%\end{array}$ & $\begin{array}{c}\text { Enz. } \\
\%\end{array}$ & $\begin{array}{c}\text { Exp } \\
\%\end{array}$ & $\begin{array}{c}\text { Enz. } \\
\%\end{array}$ & $\begin{array}{c}\text { Exp } \\
\%\end{array}$ & $\begin{array}{c}\text { Enz. } \\
\%\end{array}$ & $\begin{array}{c}\text { Exp. } \\
\%\end{array}$ & Enz. & $\begin{array}{c}\text { Enz. } \\
\%\end{array}$ & $\begin{array}{c}\text { Enz. } \\
\%\end{array}$ & $\begin{array}{c}\text { Exp } \\
\%\end{array}$ \\
\hline P1 & 74 & 75 & 80, & 4,6 & 31,8 & 41,6 & 27,2 & 23,2 & 16 & 8,5 & 21,5 & 9,4 & - & - \\
\hline P2 & 30 & 58 & 53,3 & 65,5 & 85,9 & 43,4 & 84 & 9,2 & 8 & 87 & 81,6 & 14,6 & - & - \\
\hline P3 & 13,5 & 39,5 & 85,9 & 58,1 & 73,4 & 40,1 & 48,8 & 7,2 & & 8,6 & 21,2 & 0,85 & 20 & 1,13 \\
\hline P4 & & & 75,2 & 52,2 & 35,2 & 45,2 & 29,6 & 6,9 & & 10 & 44,3 & & 1 & 0 \\
\hline P5 & & & & & & & 2,2 & & & & 1,7 & & 0 & 0 \\
\hline P6 & & & & & & & & & & & 9 & & 7,2 & 0 \\
\hline P7 & & & & & & & & & & & & & 0,9 & 0,12 \\
\hline & & & & & & & & & & & & & 0 & \\
\hline & & & & & & & & & & & & & 0,04 & \\
\hline
\end{tabular}




\section{ANEXO A- Aprovação do Comitê de Ética do IPEN}

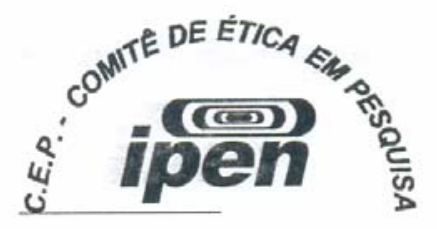

Parecer - Projeto № 087/CEP-IPEN/SP

Com base nos pareceres apresentados pelos relatores, o protocolo de pesquisa "Cultura primária de queratócitos bucais humanos", de responsabilidade da pesquisadora Mônica Beatriz Mathor, foi considerado APROVADO.

Tendo em vista a legislação vigente, devem ser encaminhados, a este Comitê, relatórios anuais (parciais ou finais, dependendo da duração do projeto) referentes ao andamento da pesquisa. Após o término da pesquisa, uma cópia do trabalho, em CD ou disquete, deve ser encaminhada a este CEP.

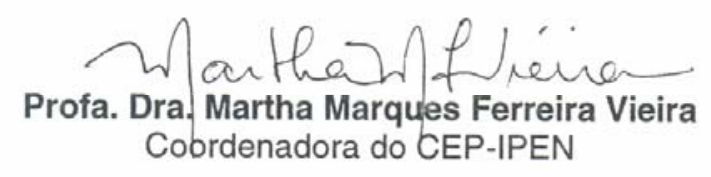

IPEN-CNEN/SP

COMITÊ DE ÉTICA EM PESQUISA

Travessa "R", № 400 - Cidade Universitária - CEP 05508-900 - São Paulo - SP

Telefone: (011) 3816-9381 - Fax (011) 3816-9123

E-mail: mmvieira@ipen.br 


\section{ANEXO B Termo de consentimento pós-informação - IPEN}

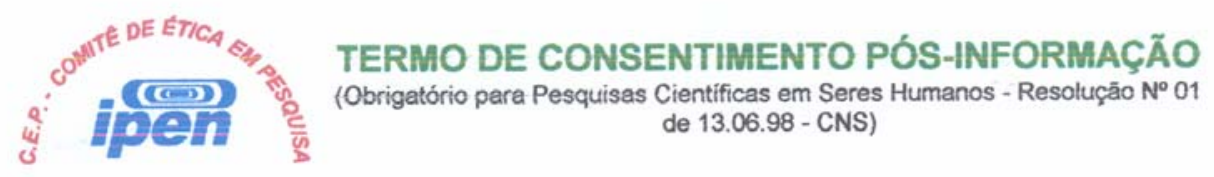

\begin{tabular}{|l|c|c|}
\hline 1. Nome do Paciente: \\
\hline Documento de Identidade $\mathrm{n}^{\circ}$ & Sexo: & $\begin{array}{c}\text { Data de Nascimento: } \\
/ /\end{array}$ \\
\hline Endereço: & \\
\hline
\end{tabular}

\begin{tabular}{|l|c|}
\hline 2. Responsável legal: \\
\hline \multicolumn{1}{|l|}{ Documento de Identidade $n^{\circ}$} & Sexo: \\
\hline Endereço: \\
\hline Natureza (grau de parentesco, tutor, curador, etc): \\
\hline
\end{tabular}

Paciente faz parte de grupo năo diferenciado? $\quad \square \operatorname{Sim} \quad \square$ Não

\section{II - DADOS SOBRE A PESQUISA CIENTIFICA}

1. Título do protocolo de pesquisa:

Cultura Primária de Queratinócitos Bucais Humanos

2. Pesquisador responsável:

Maria Fátima Guarizo Klingbeil

\begin{tabular}{l|l|l}
\hline Cargolfunçăo: & Inscr. Cons. Regional: & Unidade do IPEN
\end{tabular}

aluna de mestrado

Crosp 23.425

CTR

3. Avaliação do risco da pesquisa: (probabilidade de que o indivíduo sofra algum dano como consequêencia imediata ou tardia do estudo).
\SEM RISCO
$\square$ RISCO MíNIMO
RISCO MÉDIO
$\square$ RISCO MAIOR

4. APROVAČ̃̃O DO PROTOCOLO DE PESQUISA PELA COMISSÃO DE ÉTICA PARA NAÁLISE DE PROJETOS DE PESQUISA EM $.19 / 04 / 2004$

5. Duração da Pesquisa: 3 anos 


\title{
ANEXO B -Termo de consentimento pós-informação- IPEN
}

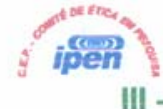

\author{
TERMO DE CONSENTIMENTO PÓS-INFORMAÇÃO
}

\section{III - EXPLICAÇÕES DO PESQUISADOR AO PACIENTE OU SEU} REPRESENTANTE LEGAL

1. justificativa e os objetivos da pesquisa (explicitar):

Testar, comparar e avaliar diferentes métodos para a obtençăo de cultura de queratinócitos bucais, a partir da mucosa bucal humana obtida cirurgicamente.

2. procedimentos que serão utilizados e propósitos, incluindo a identificaçăo dos procedimentos que săo experimentais: (explicitar)

Obtençăo do tecido da mucosa oral humana para a realizaçăo da cultura primária de queratinócitos.

Isolamento das células do tecido (queratinócitos), testadas por diferentes métodos: Método Enzimático e

Método do Explante Direto.

3. desconfortos e riscos esperados: (explicitar)

Nenhum.

4. beneficios que poderão ser obtidos: (explicitar)

Beneficio cientifico e de novas técnicas que permitirão enxertos bucais.

5. procedimentos alternativos que possam ser vantajosos para o individuo: (explicitar) Nenhum.

6. esclarecimentos sobre a garantia de receber resposta a qualquer pergunta ou esclarecimento, a qualquer dúvida acerca dos procedimentos, riscos, beneficios e outros assuntos relacionados com a pesquisa e o tratamento do individuo:

$$
\triangle \operatorname{Sim}
$$

7. esclarecimentos sobre a liberdade de retirar seu consentimento a qualquer momento e deixar de participar no estudo, sem que isto traga prejuizo à continuaçäo do seu cuidado e tratamento
凶Sim
$\square$ Não

8. compromisso sobre a segurança de que não identificará o indivíduo e que se manterá o caráter confidencial da informação relacionada com a sua privacidade.
$\triangle \operatorname{Sim}$
$\square$ Nåo

9. disposição e compromisso de proporcionar informaçōes obtidas durante o estudo, quando solicitada, ainda que possa afetar a vontade do individuo em continuar participando

$$
凶 \operatorname{sim}
$$

10. disponiblidade de assistência no caso de complicaçōes e danos decorrentes da pesquisa. $凶 \operatorname{sim}$ $\square$ Năo

11. OBSERVAÇŐES COMPLEMENTARES

NENHUMA

\section{IV - CONSENTIMENTO PÓS-ESCLARECIDO}

Declaro que, após ter sido convenientemente esclarecido pelo pesquisador, conforme registro nos itens 1 a 11, do inciso III, consinto em participar, na qualidade de paciente, do Projeto de Pesquisa referido no inciso II.

Assinatura

São Paulo, / 12006 


\section{ANEXO C Instrumento de doação de tecidos bucais -FOUSP. INSTRUMENTO DE DOAÇÃO DE TECIDOS BUCAIS}

\section{Identificação do Doador}

Nome:

Data de Nascimento: Local de Nascimento: UF:

RG no: CPF $n^{\circ}$

Endereço:

$-$

Cidade : UF: CEP:

Telefones para contato: Email

\section{DECLARAÇÃo}

Declaro ter sido esclarecido sobre quais os motivos que levaram a necessidade de remoção do(s) tecido(s) bucal(is) - por razões estéticas e funcionais, e concordo que a mesma seja utilizada na pesquisa de título "Cultura primária de queratinócitos bucais humano" - que objetiva comparar e avaliar os métodos pré existentes.

Fui ainda esclarecido pelo pesquisador que minha identidade não será divulgada por qualquer meio e que o material recolhido será utilizado unicamente para a presente pesquisa.

São Paulo, de de 2006. 


\section{ANEXO D Instrumento de doação de tecido bucal proposto pela FOUSP (cirurgiões dentistas)}

\section{Doação de Tecido Bucal}

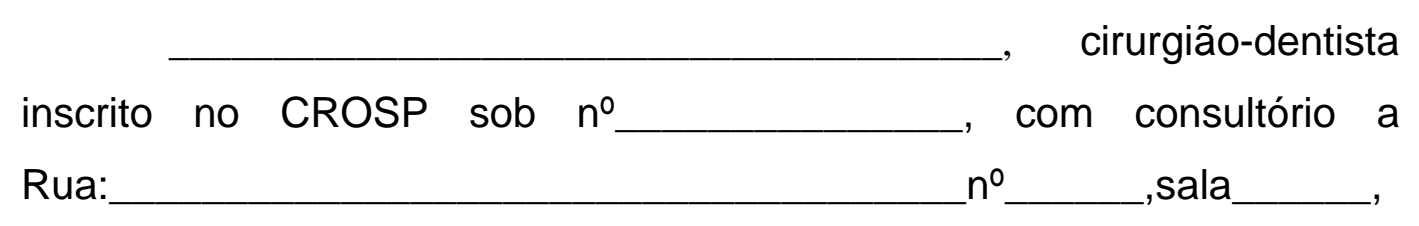

(S.P.) vem por esta e melhor forma de direito

\section{DOAR}

à CD. Maria Fátima Guarizo Klingbeil, CROSP 23.425, para fins de pesquisa aprovada pelo Comitê de Ética em Pesquisa, do IPEN (Instituto de Pesquisas Energéticas e Nucleares), sob o $\mathrm{N}^{\circ} 087$, tecido epitelial, declarando, sob as penas da lei ${ }^{\star}$, que este tecido bucal, objeto da presente doação foi extraído por indicação terapêutica, cujo histórico circunstanciado faz parte do prontuário do paciente de quem se origina, e que se encontra arquivado sob minha responsabilidade.

São Paulo, de de 2006.

\section{Assinatura}

* Resolução do Conselho Nacional de Saúde 196/96 (... que cumpre as disposições da Constituição da República Federativa do Brasil de 1988 e da Leaislacão Brasileira. entre as auais está a Lei 8489 de 


\section{REFERÊNCIAS BIBLIOGRÁFICAS:}

1. Allegra, F.; Gennari, P.U.; As Doenças da Mucosa Bucal. Livraria Santos Editora Com. Imp. Ltda. São Paulo, 2000.

2. Alvares, O.F.; Meyer, J. Introduction In The Structure and Function of Oral Mucosa.cap 1 1984. Meyer, J, Squier, C.A.;Gerson, S.J. 1st ed. Pergamon Press, New York. p. 1-6.

3. Asselineau, D.; Bernard, B.A.; Bailly, C.; Darmon, M.; Pruniéras, M. Human Epidermis Reconstructed by Culture: 'Is It Normal'? The Journal of Investigative Dermatology. v. - 86, 181-186, 1986.

4. Barnes, D.; Sato, G. Methods for Growth of Culture Cells in Serum-Free Medium. Anal Biochem. March 1,102 (2): 255-270, 1980

5. Barrandon, Y.; Green, H. Cell size as a determinant of the clone-forming ability of human keratinocytes. Proc. Natl. Acad. Sci. v. - 82: 5390-5494, Aug. 1985.

6. Barrandon, Y.; Green, H. Three clonal types with different capacities for multipication. Proc. Natl. Acad. Sci. Vol. 84: 2302-2306, April 1987.

7. Barrandon, Y. The epidermal stem cell: an overview. Developmental Biology, v. - 4: 209-215, 1993.

8. Barreca, A.; De Luca, M.; Del Monte, P.; Bondanza, S.; Damonte, G.; Cariola, G.; Di Marco, E.; Giordano, G.; Cancedda. R.; Minuto,F. In Vitro Paracrine Regulation of Human Keratinocyte Growth by FibroblastDerived Insulin-Like Growth Factors. Journal of Cellular Physiology. 151: 262-268, 1992.

9. Bhargava, S.; Chapple, C.R.; Bullock, A.J.; Layton, C.; Macneil, S.; Tissue- engineered buccal mucosa for substitution urethroplasty. B.J.U International.: Apr; 93 (6): 807-811. 2004.

10. Bath-Balogh, M.; Fehrenbach, M.J. Ilustrated Dental Embriology, Histology, and Anatomy. Philadelphia, PA W. B. Saunders Co, 1997.

11. Benassi, L.; Marconi, A.; Sevignani, C; Vaschieri, C.; Zambruno, G.. Metodiche di coltura di cheratinociti umani normali. In: Zambruno, G.; Cancedda, R.; De Luca, M.; Andreassi, L., ed.. Colture di cheratinociti umani normali e loro applicazioni. Workshop di biologia cellulare e immunologia della cute Modena, Universitá degli Studi di Modena. p. 523, 1993.

12. Billingham, R.E.; Reynolds, J. Transplantation Studies on Sheets of Pure Epidermal Epithelium and on Epidermal Cell Suspensions. British. Journal of Plastic Surgery. v. - 23, 25-36, 1952. 
13. Bloom,W.; Fawcett, D. W. Tratado de Histologia. Rio de Janeiro: Interamericana, 1977.

14. Bloor, B.K.; Tidman, N.; Leigh, I.M.; Odell, E.; Dogan, B.; Wollina, U.; Ghali, L.; Waseem, A. Expression of Keratin K2e in Cutaneous and Oral Lesions. Association with Keratinocyte Activation, Proliferation, and Keratinization. American Journal of Pathology. March, vol 162 (3)936975, 2003.

15. Bodner, L.; Grossman, N.; Autologous cultured mucosal graft to cover large intraoral mucosal defectts: A clinical study. 2003 American Association of Oral and Maxillofacial Surgeons. Journal of Oral Maxillofacial Surgery. 61: 1699-173, 2003.

16. Borysenko, J.Z.; Revel, J.P. Experimental Manipulation of Demosome Structure. Am. Journal Anat. August; v.- 137(4): 403-421, 1973.

17. Bowden, P.E. Keratins and other epidermal proteins. In: Priestley, G.C. Molecular aspects of dermatology,. Chichester: Juhn Wiley \& Sons Ltd, 1993. p. 19-54.

18. Breidahl, A.F.; Judson, R.T.; Clunie, G.J.A. Review of Keratinocyte culture techniques: Problems of growing skin. Aust. N. Z. J. Surg. v. - 59, 485497, 1989.

19. Briggaman, R.A.; Abele, D.C.; Harris, B.A.; Wheeler Jr., C.E. Preparation and Characterization of a Viable Suspension of Postembryonic Human Epidermal Cells. The Journal of Investigative Dermatology. v. - 48 (2) 159-168, 1967.

20. Bruce, A. Johnson, A., Lewis, J. Raff, M., Roberts, K., Walter, P. Molecular Biology of The Cell, fourth edition United States of America Garland Science, 2002.

21. Bussad, W. O.; Morettin, P. Estatística Básica $5^{\circ}$ edição, Editora Saraiva, 2003.

22. Carrel, A; Burrows, M.T. Cultivation of adult tissues and organs outside the body. JAMA, v. 55 (16): 1379-1381, 1910.

23. Chen, S.Y.; Meyer, J. Regional Differences in Tonofilaments and Keratohyaline Granules. In: Squier, C.A; Meyer, J. Current Concepts of the Histology of Oral Mucosa.. Christopher Alan Squier.(Ed.) Springfield: C C Thomas Book, 1971. cap. 6, p. 114-128.

24. Chen, S.Y.; Squier, C.A. The Structure and Function of Oral Mucosa 1984. cap. 2, The Ultrastructure of the Oral Epithelium. p. 7-31.

25. Cho, K.H.; Ahn, H.T.; Park, K.C.; Chung, J.H.; Kim, S.W.; Sung, M.W.; Kim, K.H.; Chung, P.H.; Eun, H.C.; Youn, J.I. Reconstruction of human hard-palate mucosal epithelium on de-epidermized dermis. Journal of Dermatological Science. 22 (2): 117-124, 2000. 
26. Davis, W.L.; Oral Histology, Cell Structure and Function. Philadelphia, PA W. B. Saunders Co, 1986. cap. 13, The Oral Mucosa. p. 179-198.

27. De Luca, M.; Tamura, R.N./ Kajiji, S./ Bondanza, S; Rossino, P.; Cancedda, R.; Marchisio, P.C.; Quanranta, V. Polarized integrin mediates human keratonocyte adhesion to basal lamina. Proc. Natl. Acad. Sci. September, v. - 87: 6888-6892, 1990.

28. De Luca, M.; Albanese; E., Megna, M.; Cancedda, R.; Mangiante, P. E.; Cadoni, A.; Franzi, A. T. Evidence that Human Oral Epithelium reconstituted in vitro and tranplanted onto patients with defects in the oral mucosa retains properties of the original donor site. Transplantation. Vol. 50 (3): 454-459, 1990.

29. De Luca, M.; M.; Cancedda, R. Culture of Human Epithelium. Burns, 18 (1) S5-S10, 1992.

30. Eckert, R.L.; Crich, J.F.; Robinson, N.A. The Epidermal Keratinocyte as a Model for the Study of Gene Regulation and Cell Differentiation. Physiological Reviews, April, v. 77 (2), 397-424, 1997.

31. Eisinger, M.; Lee, J.S.; Hefton, J.M.; Darzynkiewicsz, Z.; Chiao, J.W.; Harven, E. Human epidermal cell cultures: Growth and differentiation in the absence of dermal components or medium supplements. Proc. Natl. Acad. Sci. October, vol 76, (10): 5340-5344, 1979.

32. Eisinger, M; Monden, M.; Raaf, J.H.; Phil, D.; Fortner, J.G. Wound coverage by a sheet of epidermal cells grown in vitro from dispersal single cell preparations. Surgery. August, vol 88 (2): 297-293, 1980.

33. Eisinger, M.; Sadan, S.; Silver, I.A.; Flick, R.B. Growth regulation of skin cells by epidermal cell-derived factors: Implications for wound healing. Proc. Natl. Acad. Sci.. March, vol. 85, 1937-1941, 1988.

34. Formanek, M.; Millesi, W.; Willeim, M.; Scheiner, O.; Kornfehl, J.; Optimized growth medium for primary culture of human oral keratinocytes. Int. J. Oral Maxillofac. Surg. 25:157-160, 1996.

35. Freshney, R. I. Introduction. In: Freshney, R. I. (Ed) Culture of epithelial cells. New York: Wiley-Liss, 1992, p. 1-23.

36. Freshney, R. I. Animal cell culture; a practical approach. cap.1 (1-14), 2nd ed. Oxford University Press, 1994.

37. Freshney, R. I. Culture of animal cells: a manual of basic techniques cap.11 (149-177) 4th ed. United States of America: Willey-Liss, 2000.

38. Fusenig, N.E. Culture of epithelial cells. Freshney, R.I. 1992. cap. 2, Cell Interaction and Epithelial Differentiation. p. 25-57.

39. Gasparoni, A.; Fonzib, L.;. Schneidera, G.B.;. Wertza, P.W.; Johnsona, G.K.; Squier, C.A. Comparison of differentiation markers between normal 
and two squamous cell carcinoma cell lines in culture. Archives of Oral Biology. vol 49: 653-664, 2004.

40. Green, H.; Kehinde, O.; Thomas J. Growth of cultured human epidermal cells into multiple epithelia suitable for grafting. Proc. Natl. Acad. Sci, v76(11), 5665-5668,1979.

41. Grossman, N; Bodner, L Application of Banked Autologous Mucosal Cells to Graft Large Intraoral Mucosal Defects Cell Tissue Bank 2(4):241-247, 2001.

42. Grossman, N.; Slovik Y.; Bodner, L. Effect of donor age on cultivation of human oral mucosal keratinocytes. Archieves of Gerontology and Geriatrics. March-April, 38 (2), 114-122, 2004

43. Hansson, A.; Bloor, B.K.; Sarang, Z.; Haig, Y.; Morgan, P.R.; Stark, H-J.; Fusenig, N.E.; Ekstrand, J.; Graström, R.C. Analysis of proliferation, apoptosis and keratin expression in cultured normal and immortalized human buccal keratinocytes. European Journal of Oral Science; 111: 43-41, 2003.

44. Hawley-Nelson, P.; Sullivan, B.S.; Kung, M. Hennings, H. Yuspa, S.H. Optimized Conditions for Growth of Human Epidermal Cells in Culture. The Journal of Investigative Dermatology. 75: 176-182, 1980.

45. Herson, M.R. Estudo da composição in vitro de substituto cutâneo dermo-epidérmico constituído por epitélio de queratinócitos cultivados sobre base dérmica alógena, São Paulo, 1999. 141p. Tese (Doutorado). Faculdade de Medicina da Universidade de São Paulo.

46. Hudson, L.G.; McCawley, L.J. Contributions of the Epidermal Growth Factor Receptor to Keratinocyte Motility. Microscopy Reasearch and Technique Dec, 1- 43(5):444-4555, 1998

47. Invitrogen - GIBCO Cell Culture Products. Disponível em < http//www.invitrogen.com>. Acesso em 29 set. 2006.

48. Iqbal, M.; Gerson, S. Biochemical Features of Oral Epithelium.In Squier, C.A; Meyer, J. Current Concepts of the Histology of Oral Mucosa.. Christopher Alan Squier.(Ed.) Springfield: C C Thomas Book, 1971. cap. 2, p34-60.

49. Jaakkola, P.; Kontusaari, S.; Kauppi, T.; Maatta, A.; Jalkanen, M. Wound reepithelialization activates a growth factor-responsive enhancer in migrating keratinocytes. The FASEB Journal. vol 12: 959-969, 1998.

50. Junqueira, L.C.; Carneiro, J. Histologia Básica $8^{\circ}$ edição, 1995. Editora Guanabara Koogan S.A., Rio de Janeiro.

51. Kang, Mo K.; Bibb, C.; Baluda, M.A.; Rey, O.; Park No-Hee. In vitro replication and differentiation of normal human oral keratinocytes. Experimental Cell Research. 258: 288-297, 2000. 
52. Karasek, M.A. Culture of Human Keratinocytes in Liquid Medium. The Journal of Investigative Dermatology. 81: 24-28, 1983.

53. Kedjarune,U.; Pongorerachok, S.; Arpornmaekklong, $\mathrm{P}$.;Ungkusonmongkhon $\mathrm{K}$. Culturing primary human gingival epithelial cells: comparison of two isolation techniques. Journal of CranioMaxillofacial Surgery. (29) 224-231, 2001.

54. Koss, L.G. Diagnostic Cytology and its Histopathologic Bases 4th ed. vol.1 1992. J.B. Lippincott Company- Philadelphia.

55. Langdon, J.; Williams, D.M.; Navsaria, H.; Leigh, I.M. Autologous keratinocytes grafting: a new technique for intra-oral reconstruction. British Dental Journal 10-24; 171 (3-4): 87-90, 1991.

56. Laskaris, G.; Scully, C. Manifestações Periodontais das Doenças Locais e Sistêmicas. $1^{\circ}$ edição. Santos-Livraria Editora, 2005.

57. Lauer, G. Autografting of feeder-cell free cultured gingival epithelium. Method and clinical application. Journal of cranio,-maxillo-facial surgery ; 22 (1) 18-20, 1994.

58. Lauer, G.;Schimming, R.; Tissue-engineered mucosa graft for reconstruction of the intraoral lining after freeing of the tongue: A clinical and imunohistologic study. Journal of Oral and Maxillofacial Surgery 59 (2) 169-175; discussion 175-177, 2001.

59. Lauer, G. Siegmund, C.; Hübner, U. Influence of donor age and culture conditions on tissue engineering of mucosa autografts. International Journal of Oral and Maxillofacial Surgery. 32: p 305-312. 2003

60. Lavker, R.M.; Sun, T.T. Epidermal Stem Cells. The Journal of Investigative Dermatology. 81 (1): 121s-127s, 1983.

61. Mackenzie, I.C.; Hill, M.W. Connective tissue influences on patterns of epithelial architecturen and keratinization in skin and oral mucosa of the adult mouse. Cell Tissue Res. 235: 551-559, 1984.

62. Mackenzie, I.C.; Fusenig, N.E. Regeneration of Organized Epithelial Structure. The Journal of Investigative Dermatology. 81, 189-194, 1983.

63. Mathor, M. B.; Estudos da expressão gênica mediante utilização de queratinócitos humanos normais transduzidos com o gene do hormônio de crescimento humano. "Possível utilização em terapia gênica”. São Paulo, 1994, 158p. Tese (Doutorado). Instituto de Pesquisas Energéticas e Nucleares - IPEN.

64. Mazzalupo, S.; Wawersik, M.J.; Coulombe. P.A. An Ex Vivo Assay to Assess the Potential of Skin Keratinocytes for Wound Epithelialization. Journal Invest Dermatology. May; 118 (5): 866-870, 2002 
65. Medawar, P.B. Sheets of pure epidermal epithelium from human skin. Nature (London), v-148: 783, 1941.

66. Medawar, P.B. The Cultivation of Adult Mammalian Skin Epithelium in vitro. Q. J. Microsc. Sci. vol 89 (6), 187-196, 1948.

67. Nadjmi, N.; Jackson, I.T. Full-thickness skin graft in the secondary repair of bilateral cleft lip. A case report. International Journal of Oral and Maxillofacial Surgery 28(3): 176-8, 1999.

68. Nakamura,T.; Inatomi,T.; Sotozono, C.; Amemiya, C.; Nakamura, N.; Kinoshita, S. Transplantation of cultivated autologous oral mucosal epithelial cells in patientes with severe ocular surface disorders. $\mathbf{B r}$. J. Ophthalmol. 88:1280-1284, 2004.

69. Parkinson, E.K.; Yeudall, W.A. Culture of epithelial cells. Feshney, R.I., 1992 cap. 3, The epidermis. p. 59-80.

70. Pellegrini, G.; Traverso, C. E.; Franzi, A.T.; Zingirian, M.; Cancedda, R.; De Luca, M.; Long-term restoration of damaged corneal surfaces with autologous cultivated corneal epithelium. Lancet April 5, 349: 990-993, 1997.

71. Presland, R.B.; Jurevic, R.J. Making sense of the epithelial barrier: what molecular biology and genetics tell us about the functions of oral mucosal and epidermal tissues. Journal of Dental Education 66 (4): 564-574, 2002.

72. Priestley, G.C. An introduction to the skin and its disease. In: Priestley, G.C. Molecular aspects of dermatology. Chichester: Juhn Wiley \& Sons Ltd, 1993. p. 1-17.

73. Pruniéras, M.; Régnier, M.; Fougère, S.; Woodley, D. Keratinocytes Sinthetisise Basal-Lamina Proteins in Culture. The Journal of Investigative Dermatology, 81: 74s-81s, 1983.

74. Pullar, C.E.; Isseroff, R.R. Cyclic AMP mediates keratinocyte directional migration in an electric field. Journal of Cell Science. vol 118: 20232034, 2005.

75. Raghoebar, G.M.; Tompson, A.M.; Scholma, J.; Blaauw, E.H.; Witjes, M.J.; Vissink, A. Use of cultured mucosal grafts to cover defects caused by vestibuloplasty: an in vivo study. Journal of Oral Maxillofacial Surgery 53 (8) 872-878: discussion 878-9, 1995.

76. Regezi, J.A.; Sciubba, J.J. Patologia Bucal. Correlações ClinicoPatológicas Rio de Janeiro: Guanabara Koogan, 2000.

77. Rheinwald, J.G.; Green, H. Formation of a keratinizing epithelium in culture by a cloned cell line derived from a teratoma. Cell , v.6: p.317-330, 1975a. 
78. Rheinwald, J.G.; Green, H. Serial cultivation of human epidermal keratinizing colonies from single cells. Cell, Vol.6: 331-344, 1975b.

79. Rheinwald, J.G.; Green, H. Epidermal growth factor and the multiplication of cultured human epidermal keratinocytes. Nature v. 265 (3): p.421-424, february 1977.

80. Rheinwald, J.G.; Hahn, W.C.; Ramsey, M.R.; Wu, J.Y.; Guo, Z.; Tsao, H., De Luca, M.; Catricalà, C.; O'Toole, K.M. A Two-Stage, p16 INK4A and p53_Dependent Keratinocyte Senescence Mechanism That Limits Replicative Potencial Independent of Telomere Status. Molecular and Cellular Biology, July, v-22(14): 5157-5172, 2002

81. Schroeder, H.E. Oral Structural Biology. Oral Mucosa Thieme Medical Publishers, Inc., New York. 1991. cap.6 350- 387.

82. Selvaratnam, L.; Cruchley, A.T.; Navsaria, H.; Wertz, P.W.; Hagi-Pavli, E.P.; Leigh, I.M.; Squier, C.A.; Williams, D.M. Permeability barrier properties of oral keratinocyte cultures: a model of intact human oral mucosa. Oral Diseases. vol 7: 252-258, 2001.

83. Shipley, G. D.; Pittelkow, M.R. Control of growth and differentiation In Vitro of human keratinocytes cultured in serum-free medium. Arch Dermatol. Nov. 123: 1541-1. 1987.

84. Silverman, S. Nonkeratinization and Keratinization: the Extremes of the Human Range. In: Squier, C.A; Meyer, J. Current Concepts of the Histology of Oral Mucosa.. Christopher Alan Squier.(Ed.) Springfield: C C Thomas Book, 1971. cap. 4, p. 80-96.

85. Squier, C.A. Intruduction. In: Squier, C.A; Meyer, J. Current Concepts of the Histology of Oral Mucosa.. Christopher Alan Squier.(Ed.) Springfield: C C Thomas Book, 1971. cap. 1, p. 5-33.

86. Squier, C.A; Johnson, N.W.; Hackemann, M. Structure and Function of Normal Human Oral Mucosa. 1975. cap.1 Structure and Function. p. 1101. Edited by A.E. Dolby Blackwell

87. Squier, C.A,; Johnson, N.W.; Hopps, R. Human Oral Mucosa. Development, Structure and Function, 1976. Blackwell Scientific Publications.

88. Squier, C.A.; Kremer, M.J. Biology of Oral Mucosa and Esophagus. Journal of the National Cancer Institute Monographs , 29 : 7-15, 2001.

89. Staiano-Coico, L.; Higgins, P.J.; Darzynkiewicz, Z.; Kimmel, M. Gottlieb, A.B.; Pagan-Charry, I. Madden, M.R.; Finkelstein, J.L.; Hefton, J. Human Keratinocyte Culture; Identification and Staging of Epidermal Cell Subpopulations. J. Clin. Invest. February, vol 77: 396-404, 1986. 
90. Sumi, Y.; Hata, K.I.; Sawaki, Y.; Mizuno, H.; Ueda, M. Clinical application of cultured oral epithelium for palatal wounds after palatoplasty: a preliminary report. Oral Disease 5 (4): 307-12, 1999.

91. Sumi, Y.; Hata, K.I.; Sawaki, Y.; Mizuno, H.; Ueda, M. Cultured oral epithelium as an effective biological dressing using for palatal wounds after palatoplasty. Materials Science and Engineering. vol 13: 39-44, 2000.

92. Takashi, M.; Izumi, Y.; Sueda, T. Culture and characterization of human junctional epithelial cells. Journal of Periodontoly. March, vol 68 (3): 229-239, 1997.

93. Ten Cate, A.R. Histologia Bucal, Desenvolvimento, Estrutura e Função. Rio de Janeiro: Guanabara Koogan, 2001.

94. Tsao, M.C.; Walthall, B.J.; Ham, R.G. Clonal Growth of Human Epidermal Keratinocytes in a Definied Medium. Journal of Cellular Physiology. Feb, 110 (2): 219-229, 1982.

95. Ueda, M.; Hata, K.; Horie, K.; Torii, S. The potential of oral mucosal cells for cultured epithelium: a preliminary report. Ann. Plast. Surgery ; 35(5): 498-504, 1995.

96. Ueda, M.; Hata, K.; Sumi, Y.; Mizuno, H.; Niimi, A. Peri-implant soft tissue management through use of cultured mucosal epithelium. Oral Surgery, Oral Medicine, Oral Pathology, Oral Radiology and Endodontics. Vol. 86(4) 393-400, 1998.

97. Uvo, S.A.; Beretta, E.M. Mixoma of maxilla in a child, report of case and review of the literature. Rev. Hosp. Clin. Fac. Med. São Paulo; 51(3): 99-102, 1996.

98. Wang, H.J.; Chen, T.M.; Cheng, L.F.; Cheng, T.Y.; Tung, Y.M. Human keratinocyte culture using porcine pituitary extract in serum-free medium. Burns. vol 21 (7): 503-506, 1995.

99. Wilke, M.S.; Hsu, B.M.; Wille Jr, J.J.; Pittelkow, M.R. Scott, R.E. Biologic Mechanisms for the Regulation of Normal Human Keratinocyte Proliferation and Differentiation. American Journal of Pathology. April, vol 131 (1): 171-181, 1988.

100. Wille Jr., J.J.; Pittelkow, M.R.; Shipley, G.D.; Scott, R.E. Integrated Control and Differentiation of Normal Human Prokeratinocytes Cultured in Serum-Free Medium: Clonal Analyses, Growth Kinetics, and Cell Cycle Studies. Journal of Cellular Physiology. Oct 121 (1): 31-44, 1984.

101. Wright, K.A.; Nadire, K.B.; Busto, P.; Tubo, R.; McPherson, J.M.; Wentworth, B.M. Alternative delivery of keratinocytes using a polyurethane membrane and the implication for its use in the treatment of full-thickness burn injury. Burns 24, 7-17, 1998. 
102. Yaeger, P.C.; Stiles, C.D.; Rollins,B.J. Human keratinocyte growthpromoting activity on the surface of fibroblasts. Journal of Cellular Physiology. 149: 110-116, 1991.

103. Yates, R.A.; Manney, L. B.; Gates, R.E.; King Jr., L.E. Epidermal Growth Factor and related Growth Factors. International Journal of Dermatology. October, vol 30 (10): 687-694, 1991.

104. Yoshizawa, M; Feinberg, S.E.; Marcelo, C.L. Ex vivo produced human conjunctiva and oral mucosa equivalents grown in a serum-free culture system. J. Oral Maxilofac. Surg.Aug; 62 (8): 980-988, 2004.

105. Yuspa, S.H; Hawley-Nelson, P.; Stanley, J.R.; Hennings, H. Epidermal Cell Culture. Transplantation Proceedings. September, v. -I 12 (3) 1: 114-121, 1980.

106. Yuspa, S.H.; The pathogenesis of squamous cell cancer: lessons learned from studies of skin carcinogenesis. Review Article. Journal of Dermatological Science. 17:1-7, 1998.

107. Zeineldin, R.; Hudson, L.G. Epithelial cell migration in response to epidermal growth factor. Methods Mol. Biol. 327; 147-158, 2006.

108. Zhu, W.Y.; Zhan, R.Z.; Ma, H.J.; Wang. D.G. Isolation and Culture of Amelanotic Melanocytes from Human Hair Follicles. Original Research Article. Pigment Cell Res. Dec. v. - 17 (6): 668-673, 2004. 